EFFECT OF URBAN STORMWATER RUNOFF ON GROUND WATER

BENEATH RECHARGE BASINS ON LONG ISLAND, NEW YORK

by Henry F. H. Ku and Dale L. Simmons

U.S. GEOLOGICAL SURVEY

Water-Resources Investigations Report 85-4088

Prepared in cooperation with

LONG ISLAND REGIONAL PLANNING BOARD

Syos set, New York 


\section{UNITED STATES DEPARTMENT OF THE INTERIOR}

DONALD PAUL HODEL, Secretary

GEOLOGICAL SURVEY

Dallas L. Peck, Director

For additional information write to:

U.S. Geological Survey

5 Aerial Way

Syosset, New York 11791

(516) 938-8830
Copies of this report may be purchased from:

Open-File Services Section Western Distribution Branch U.S. Geological Survey Box 25425, Federal Center Denver, Colo. 80225

(303) 234-5888 
Abstract. . . . . . . . . . . . . . . ...... 1

Introduction. . . . . . . . . . . . . . . . . . . . 2

Purpose and scope....................... 3

Location and extent of study area. . . . . . . . . . . . 3

Previous studies..................... . . . 4

Acknowledgments. . . . . . . . . . . . . . . . 5

Hydrogeologic setting . . . . . . . . . . . . . . . . . 5

Hydrogeologic units. . . . . . . . . . . . . . . . 5

Precipitation. . . . . . . . . . . . . . . . . 6

Streamflow ........................ 7

Ground water ........................ . 7

Movement. . . . . . . . . . . . . . . 7

Recharge. . . . . . . . . . . . . . . . 7

Urban hydrology of Long Island... . . . . . . . . . . . 8

Population . . . . . . . . . . . . . . . . . . 8

Sewerage history and plans................... 9

Sanitary sewers....................... 9

Storm sewers and recharge basins. . . . . . . . . . . 9

Description of monitoring sites . . . . . . . . . . . . . . . 10

Centereach (commercial)..................... 10

Huntington (shopping center and parking lot)........... 11

Laure1 Hollow (low-density residential). . . . . . . . . . . 11

Plainview (highway). . . . . . . . . . . . . . . . . 11

Syosset (medium-density residential) . . . . . . . . . . . 11

Sample collection and data management . . . . . . . . . . . . 22

Sampling equipment . . . . . . . . . . . . . . . . 22

Precipitation measurement .............. 22

Stormwater and ground-water measurement . . . . . . . 23

Flow-meter calibration .............. 23

Comparison of discharge-measurement results. . . . . 24

Sample collection. . . . . . . . . . . . . . . 26

Standard chemicals. . . . . . . . . . . . . 26

Priority pollutants . . . . . . . . . . . . 26

Bacteria. . . . . . . . . . . . . . . . 27

Sample handling. . . . . . . . . . . . . . . 27

Standard chemicals. . . . . . . . . . . . . 27

Priority pollutants . . . . . . . . . . . . 27

Bacteria. . . . . . . . . . . . . . . 27

Data reduction . . . . . . . . . . . . . . . . 27

Data storage ......................... . 28

Characteristics of sampled storms . . . . . . . . . . . . . 28

Modified runoff/precipitation relationship. . . . . . . . . . . . 32

Relationship of stormwater quality to ground-water quality. . . . . . 37

Concentration of selected constituents . . . . . . . . . 37

Standard chemicals. ................. 37

Priority pollutants................ . . 46

Bacteria. . . . . . . . . . . . . . 47

Loads of selected constituents . . . . . . . . . . . 51

Standard chemicals. . . . . . . . . . . . . 52

Priority pollutants... . . . . . . . . . . . 53

Bacteria. . . . . . . . . . . . . . . . 53 


\section{CONTENTS (Continued)}

Removal of chemical constituents of runoff by soils . . . . . . . 57

Metals . . . . . . . . . . . . . . . . 57

Pesticides ...................... 57

Summary and conclusions.................. . . 59

References cited. . . . . . . . . . . . . . . . . 61

Appendix A--Standard chemical analysis. . . . . . . . . . . . 64

Appendix B--U.S. Environmental Protection Agency priority pollutants. • 64

Appendix C--Data-retrieval information. . . . . . . . . . . . . 66

Appendix D--Drinking-water standards of New York State, U.S. Public

Health Service, and U.S. Environmental Protection Agency. .

\section{ILLUSTRATIONS}

Figure 1. Map showing location of major geographic features of

Long Island, N.Y. . . . . . . . . . . . . . .

2. Map showing location of recharge basins used for storm runoff on Long Island in 1969 and of the five basins used in this study..................... 4

3. Generalized hydrogeologic section of Long Island showing major hydrogeologic units . . . . . . . . . . . . 5

4. Graph showing population of Nassau and Suffolk Counties, Long Island, N.Y., 1920-80. . . . . . . . . . .

5. Maps and aerial photographs of drainage areas at:

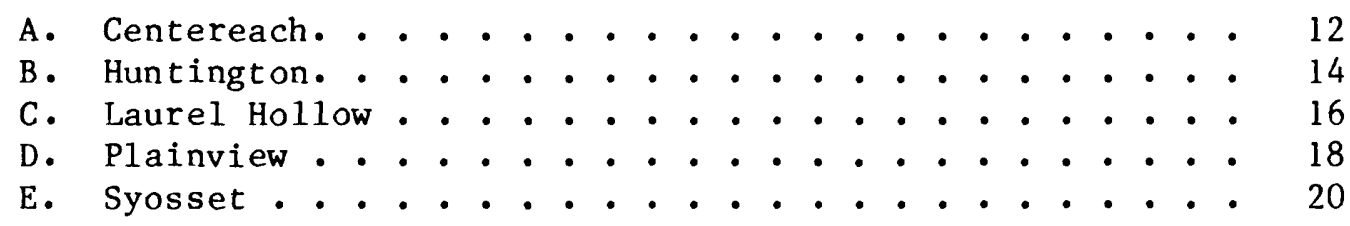

6. Schematic diagram of instrumentation at each recharge basin . . . . . . . . . . . . . . . . . . . .

7. Graphs showing relationship between discharge measured simultaneously by flow meter and by dye-dilution method at Centereach, Plainview, Laurel Hollow, and Syosset . . .

8. Graphs showing modified runoff/precipitation relationship at Centereach, Huntington, Laurel Hollow, Plainview, and Syosset . . . . . . . . . . . . . . . . . 


\section{ILLUSTRATIONS (Continued)}

Page

Figure 9. Hydrographs, hyetographs, and plots showing constituent concentrations through time during storm at:

A. Centereach, June 5, 1982... . . . . . . 41

B. Huntington, February 20, 1981 . . . . . . . . 42

C. Laurel Hollow, February 1, 1981 ........... 43

D. Plainview, February 1, 1981 ........... 44

E. Syosset, April 23, 1981 . . . . . . . . . 45

10. Plot showing flow-weighted average concentrations of nitrogen in stormwater and observed concentrations in ground water at Plainview, 1980-82. . . . . . . 52

\section{TABLES}

Table 1. Physical characteristics of major hydrogeologic units on

Long Island. . . . . . . . . . . . . . . . 6

2. Physical characteristics of recharge basins studied. . . . 22

3. Comparison of flow measurements recorded by flow meter with measurements obtained by dye-dilution methods . . . 25

4. Number of storms sampled per site, by season, 1980-82. . . 28

5. Characteristics of sampled storms, 1980-82 . . . . . . 29

6. Source and type of sample, and number of each type of analysis performed ................ 31

7. Source of samples collected for priority-pollutant analysis..................... 32

8. Median and range of modified runoff/precipitation ratio, in percent................ 33

9. Precipitation, runoff, and modified runoff/precipitation ratio for sampled storms, 1980-82. . . . . . . . 34

10. Median values of physical and chemical characteristics of stormwater, ground water, and precipitation....... 38

11. Total daily snowfall, eastern Long Island, January 2-10, 1981 . . . . . . . . . . . . . . 4 46

12. Comparison of median lead and chromium concentrations in rainfall (1980-82) and accumulated snow, January 10, 1981. . 


\section{TABLES (Continued)}

Table 13. Concentration of selected compounds at recharge basins, 1981-82:

A. Acid- and base/neutral-extractable priority pollutants . 48

B. Volatile priority pollutants, pesticides, phenols, and cyanide................ 49

14. Priority pollutants exceeding New York State drinkingwater standards at study sites . . . . . . . . 50

15. Minimum, maximum, and median number of bacteria in stormwater for all samples . . . . . . . . 50

16. Ratio of fecal coliform to fecal streptococci in stormwater . . . . . . . . . . . . . . . .

17. Flow-weighted concentrations and loads of selected constituents in stormwater and observed concentrations in water reaching the water table at recharge basins. . . .

18. Minimum, maximum, and median number of bacteria per storm for all sampled storms, per acre per inch of precipitation. . . . . . . . . . . . . 56

19. Seasonal comparison of minimum, maximum, and median number of bacteria per storm for all sampled storms, per acre per inch of precipitation. . . . . . . . . . . . 56

20. Concentrations of metals, pesticides, and polychlorinated aromatic hydrocarbons in basin soil samples, June 1981 . . 


\section{CONVERSION FACTORS AND ABBREVIATIONS}

Multiply inch-pound units

\section{inch (in) \\ foot $(f t)$ \\ mile (mi)}

acre

acre

square mile $\left(\mathrm{mi}^{2}\right)$

gallon (gal)

gallon (gal)

pound $(1 b)$

degree Fahrenheit $\left({ }^{\circ} \mathrm{F}\right)$

cubic foot per second $(\mathrm{ft} 3 / \mathrm{s})$

million gallons per day (Mgal/d)

0.02832

0.04381

Mass

453.6

Temperature

${ }^{\circ} \mathrm{C}=5 / 9\left({ }^{\circ} \mathrm{F}-32\right) \quad$ degree Celsius

\section{Abbreviations}

\author{
millimeter (mm) \\ meter (m) \\ kilometer $(\mathrm{km})$
}

square meter $\left(\mathrm{m}^{2}\right)$

hectare

square kilometer $\left(\mathrm{km}^{2}\right)$

liter (L)

cubic meter $\left(\mathrm{m}^{3}\right)$

cubic meter per second $\left(\mathrm{m}^{3} / \mathrm{s}\right)$

cubic meter per second $\left(\mathrm{m}^{3} / \mathrm{s}\right)$

gram (g) foot per mile ( $\mathrm{ft} / \mathrm{mi}$ )

milligrams per liter $(\mathrm{mg} / \mathrm{L})$

micrograms per liter $(\mu \mathrm{g} / \mathrm{L})$

milliliter (mL)

picocurie per liter (PCi/L) microgram per gram ( $\mu g / g)$

microgram per kilogram ( $\mu \mathrm{g} / \mathrm{kg})$

most probable number (MPN) 


\title{
Effect of Urban Stormwater Runoff on Ground Water beneath Recharge Basins on Long Island, New York
}

\author{
by Henry F. H. Ku and Dale L. Simmons
}

\begin{abstract}
Urban stormwater runoff was monitored during 1980-82 to investigate the source, type, quantity, and fate of contaminants routed to the more than 3,000 recharge basins on Long Island and to determine whether this runoff might be a significant source of contamination to the ground-water reservoir. Forty-six storms were monitored at five recharge basins in representative land-use areas (strip commercial, shopping-mall parking lot, major highway, low-density residential, and medium-density residential).

Runoff/precipitation ratios indicate that all storm runof $f$ is derived from precipitation on impervious surfaces in the drainage area except during storms of high intensity or long duration, when additional runoff can be derived from precipitation on permeable surfaces.

Concentrations of most measured constituents in individual stormwater samples were within Federal and State drinking-water standards. The few exceptions are related to specific land uses and seasonal effects. Lead was present in highway runoff in concentrations up to 3,300 micrograms per liter $(\mu \mathrm{g} / \mathrm{L})$, and chloride was found in parking-lot runoff in concentrations up to 1,100 milligrams per liter $(\mathrm{mg} / \mathrm{L})$ during winter, when salt is used for deicing.
\end{abstract}

The load of heavy metals was largely removed during movement through the unsaturated zone, but chloride was not removed. Total nitrogen was commonly found in greater concentrations in ground water than in stormwater; this is attributed to seepage from cesspools and septic tanks and to the use of lawn fertilizers.

In the five composite stormwater samples and nine ground-water grab samples that were analyzed for 113 U.S. Environmental Protection Agencydesignated "priority pollutants," four constituents were detected in concentrations exceeding New York State guidelines of $50 \mathrm{\mu g} / \mathrm{L}$ for an individual organic compound in drinking water: p-chloro-m-cresol (79 $\mu \mathrm{g} / \mathrm{L}$ in ground water at the highway basin); 2,4-dimethylphenol (96 $\mathrm{\mu g} / \mathrm{L}$ in ground water at the highway basin); 4-nitrophenol (58 $\mathrm{\mu g} / \mathrm{L}$ in ground water at the parking-lot basin); and methylene chloride (230 $\mathrm{g} / \mathrm{L}$ in stormwater at the highway basin). One stormwater sample and two ground-water samples exceeded New York State guidelines for total organic compounds in drinking water ( 100 $\mu \mathrm{g} / \mathrm{L})$. The presence of these constituents is attributed to contamination from point sources rather than to the quality of runoff from urban areas.

The median number of indicator bacteria in stormwater ranged from $10^{8}$ to $10^{10} \mathrm{MPN} / 100 \mathrm{~mL}$ (most probable number per $100 \mathrm{milliliters).} \mathrm{Fecal} \mathrm{coliforms}$ and fecal streptococci increased by 1 to 2 orders of magnitude during the warm season. Total coliform concentrations showed no significant seasonal differences. 
Low-density residential and nonresidential (highway and parking 1ot) areas contributed the fewest bacteria to stormwater; medium-density residential and strip commercial areas contributed the most. No bacteria were detected in the ground water beneath any of the recharge basins.

The use of recharge basins to dispose of storm runoff does not appear to have significant adverse effects on ground-water quality in terms of the chemical and microbiological stormwater constituents studied.

\section{INTRODUCTION}

The aquifer system of Long Island, N.Y. ( $\mathrm{fig} \cdot 1$ ) has been designated by the U.S. Environmental Protection Agency (USEPA) as the "sole-source aquifer" for water supply in Nassau and Suffolk Counties. (Kings and Queens Counties, in western Long Island, obtain water from upstate reservoirs.) The aquifer system receives natural recharge on 1 y from precipitation that infiltrates from the land surface to the water table.

Eastward urbanization on Long Island since the beginning of the 20th century, with the attendant construction of highways, houses, shopping centers, industrial parks, and streets and sidewalks in previously undeveloped or agricultural areas, has caused a decrease in the amount of land surface through which precipitation can infiltrate. The increased amount of impervious surface has, in turn, caused a twofold water-management problem--an increased volume of urban storm runoff from paved areas, and a loss of ground-water recharge. To eliminate the need for costly trunk storm sewers to carry runoff to coastal waters, and to minimize the loss of recharge, excavation of shallow stormwater-collection basins, known as recharge basins, was begun as early as 1935 to contain the storm runoff and allow it to infiltrate to the underlying aquifers.

Recent investigations of the chemical quality of urban runoff (Koppelman, 1978) have given rise to questions as to whether urban stormwater may contain substances that could alter the quality of ground water beneath the recharge basins. Substances that may be found in urban runoff include organic compounds, heavy metals, chloride from road salt, and bacteria; however, the extent to which they are transmitted through the unsaturated zone beneath the recharge basins to the underlying aquifers is unknown.

A 5-year study by the Nassau-Suffolk Regional Planning Board (Koppe1man, 1978) indicated that routing stormwater runoff to tidewater through streams and storm sewers is the major source of bacterial loading to the saltwater bays surrounding the island and often contributes more than 95 percent of the annual load. Excessive levels of total coliforms in the south-shore bays have caused large areas to be closed to shellfishing, which results in a significant annual economic loss to the island. The Koppelman (1978) study also indicated urban runoff to be an important source of inorganic compounds, organic matter, and sediment, as well as organic compounds, including pesticides, and suggested that urban stormwater may also contribute significant quantities of these constituents to the ground water through stormwater recharge basins. 
During 1979-83, the U.S. Geological Survey, in cooperation with the Long Island Regional Planning Board, studied the characteristics of stormwater on Long Island as part of the "Nationwide Urban Runoff Program" funded by the U.S. Environmental Protection Agency. The objectives of this study were to (1) determine the source, type, quantity, and fate of selected constituents of urban stormwater runoff in Nassau and Suffolk Counties; and (2) assess the effects of runoff diverted to selected recharge basins on the chemical and microbiological quality of ground water beneath the basins.

\section{Purpose and Scope}

This report summarizes the results of the study and presents data on runoff quantity, runoff quality, and ground-water quality beneath recharge basins after storms. A list of constituents included in standard chemical and priority-pollutant analyses is given in appendixes $A$ and $B$, respectively. A guide to computerized water-quality data and a summary of Federal and State drinking-water standards are given in appendixes $C$ and $D$, respectively. The data presented herein will help to identify sources of current or potential ground-water contamination that may result from the use of recharge basins for stormwater retention and recharge on Long Island.

\section{Location and Extent of Study Area}

Long Island, the southeasternmost part of New York State, extends eastnorth-eastward rough1y parallel to the New England coast (fig. 1). The Island is 120 miles long and has a maximum width of 23 miles. It is bounded on the north by Long Island Sound, on the east and south by the Atlantic Ocean, and on the west by New York Bay and the East River.

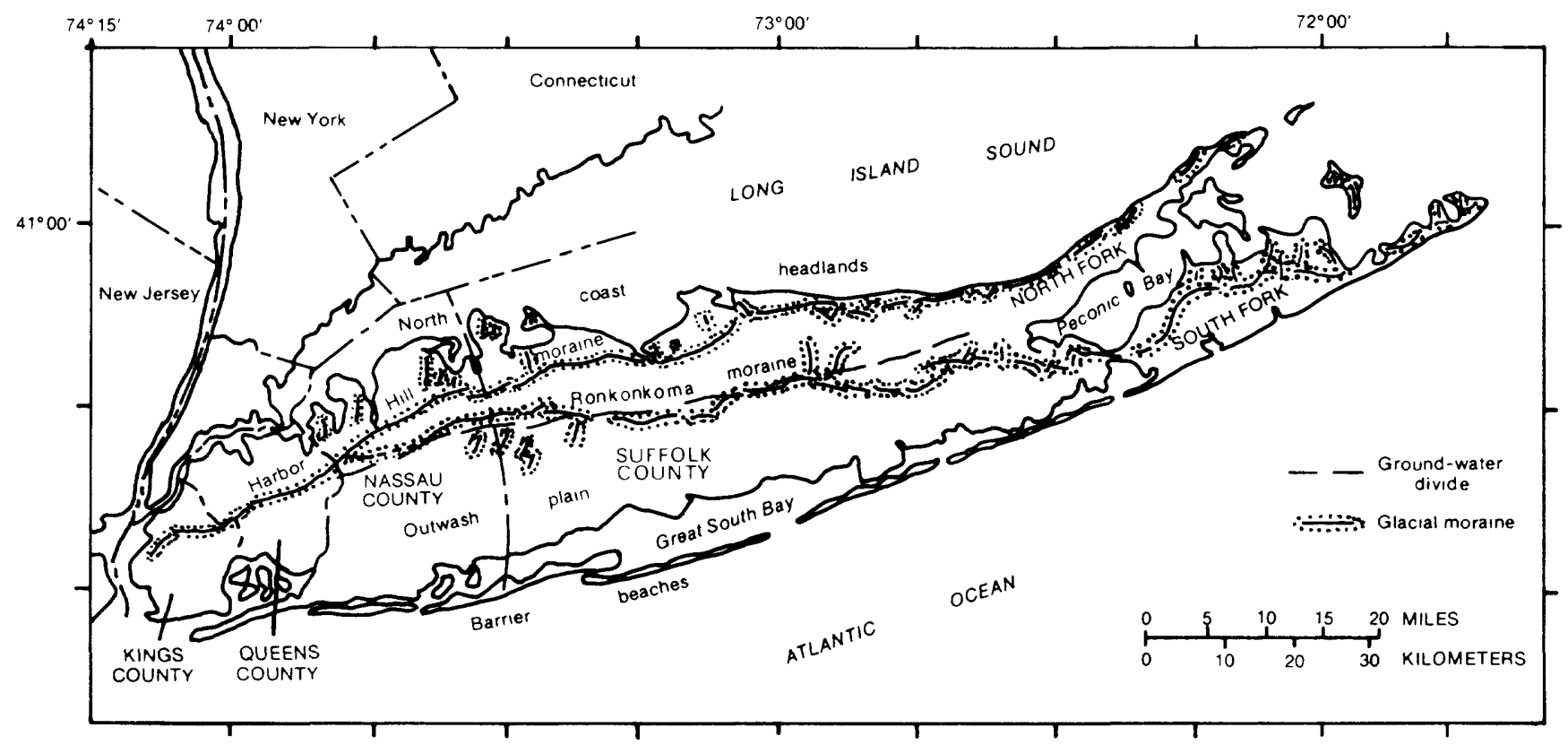

Figure 1.--Major geographic features of Long Island, N.Y. (Modified from McClymonds and Franke, 1972.) 
Long Island consists of four counties--Kings, Queens, Nassau, and Suffolk. Kings and Queens, the two westernmost counties, are boroughs of New York City. The study area, Nassau and Suffolk Counties, has a combined area of more than $1,200 \mathrm{mi}^{2}$ and contains more than 3,000 recharge basins, most of which are in eastern Nassau and western Suffolk Counties (fig. 2).

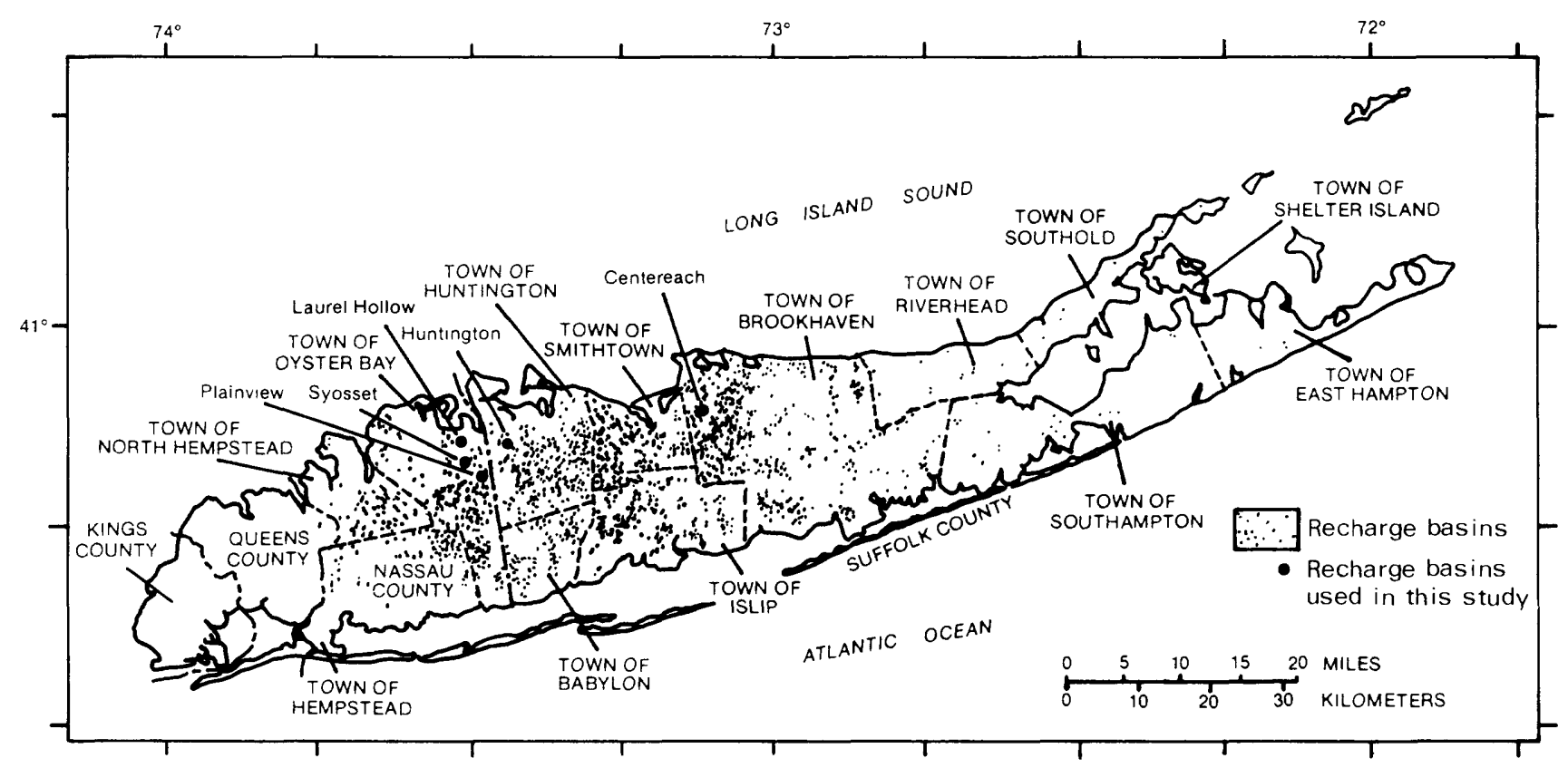

Figure 2.--Location of recharge basins used for storm munf on Long Island in 1969 and of the five basins used in this study. (Modified from Seaburn and Aronson, 1973.)

\section{Previous Studies}

The hydrology of recharge basins has been described by Brashears (1946), Brice and others (1959), Parker and others (1967), Holzmacher and others (1970), and Seaburn (1970a, 1970b). Seaburn and Aronson (1973) compiled a catalog describing the physical characteristics of more than 2,000 recharge basins in operation on Long Island in 1969. They also evaluated the operating efficiency of the recharge basins (Aronson and Seaburn, 1974) and discussed the influence of the basins on Long Island hydrology (Seaburn and Aronson, 1974). Koppelman (1978) discussed the quality of urban runoff on Long Island in detail and estimated annual constituent loading to recharge basins.

Miller and McKenzie (1978) analyzed stormwater quality near Portland, ore. Ellis and Alley (1979) examined the quantity and quality of urban runoff in the Denver, Colo., area. Mallard (1980) compiled a review of current literature on the microbiological constituents of stormwater. 


\section{Acknowledgments}

The authors thank the Long Island Regional Planning Board, particularly Executive Director Lee E. Koppelman and Edith Tanenbaum, for assistance and guidance and also thank the Suffolk County Department of Health Services for field assistance. James Adamsky of the Nassau County Department of Health, Division of Laboratories, provided services for the microbiological analyses included in this report. The Nassau County Department of Public Works and the New York State Department of Transportation provided access to their recharge basins. Special thanks are due to Ronald Shields, Operations Manager of Pembrook Management, Inc., for permission to place instruments on property managed by that firm.

\section{HYDROGEOLOGIC SETTING}

\section{Hydrogeologic Units}

Long Island is underlain by a thick sequence of unconsolidated sediments including gravel, sand, silt, and clay, which are in turn underlain by southward-dipping crystalline bedrock (fig. 3 ). The units that make up the aquifer system range in thickness from zero in northern Queens County, where bedrock is exposed, to more than $2,000 \mathrm{ft}$ in south-central Suffolk County. The characteristics of the individual aquifers and intervening confining units are summarized in table 1 .

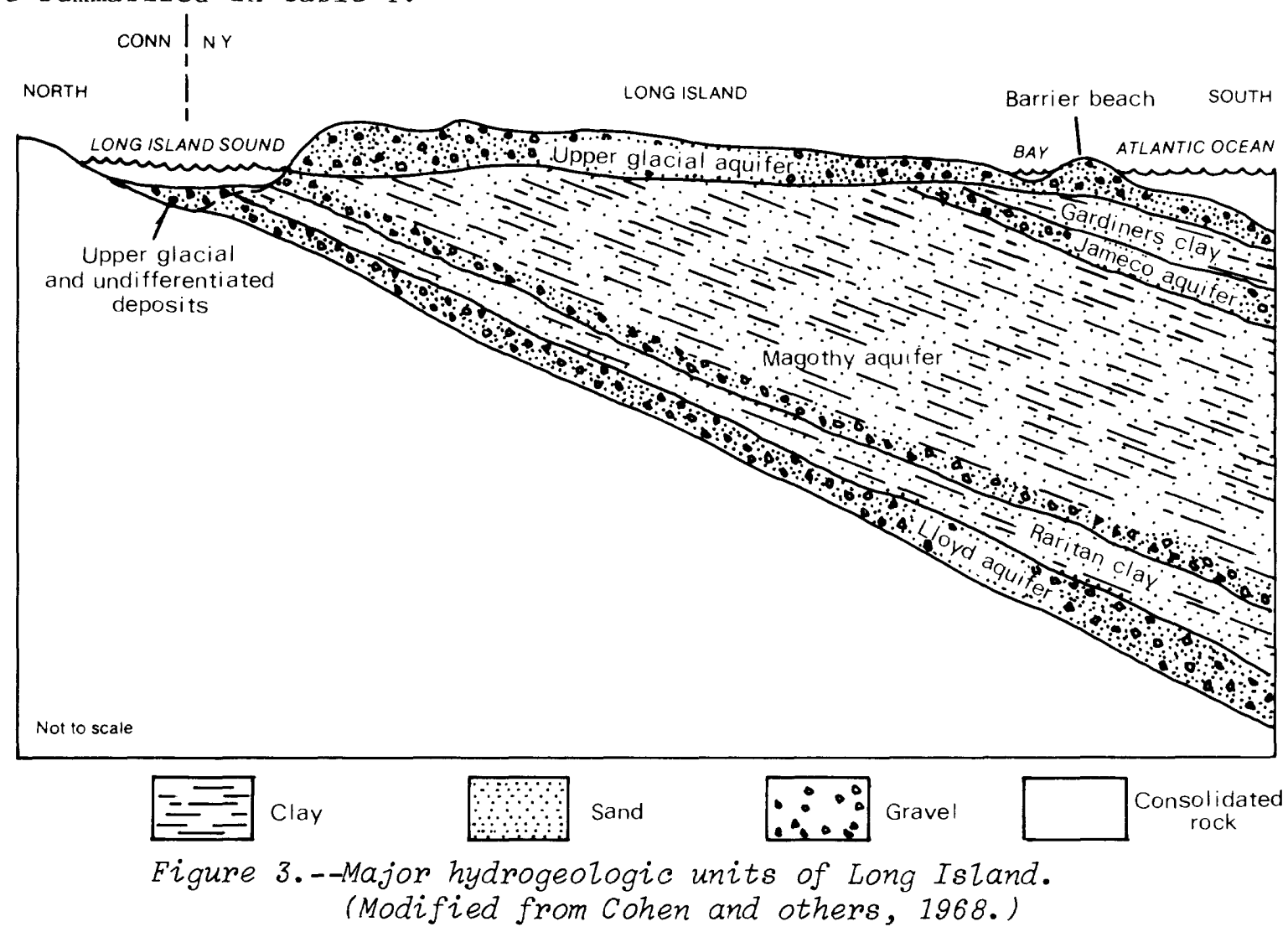


Table 1.--Physical characteristics of major hydrogeologic units on Long Island.

[From Cohen and others, 1968]

\begin{tabular}{|c|c|c|c|}
\hline $\begin{array}{l}\text { Hydro- } \\
\text { geologic } \\
\text { unit } \\
\end{array}$ & $\begin{array}{c}\text { Geologic } \\
\text { name }\end{array}$ & $\begin{array}{l}\text { Approximate } \\
\text { maximum } \\
\text { thickness } \\
\text { (ft) }\end{array}$ & Water-bearing character \\
\hline $\begin{array}{l}\text { Upper } \\
\text { glacial } \\
\text { aquifer }\end{array}$ & $\begin{array}{l}\text { Upper } \\
\text { Pleistocene } \\
\text { deposits }\end{array}$ & 400 & $\begin{array}{l}\text { Mainly sand and gravel of } \\
\text { moderate to high permeability; } \\
\text { also includes clayey deposits } \\
\text { of glacial till of low } \\
\text { permeability. }\end{array}$ \\
\hline $\begin{array}{l}\text { Gardiners } \\
\text { Clay }\end{array}$ & $\begin{array}{l}\text { Gardiners } \\
\text { Clay }\end{array}$ & 150 & $\begin{array}{l}\text { Clay, silty clay, and a little } \\
\text { fine sand of low to very low } \\
\text { permeability. }\end{array}$ \\
\hline $\begin{array}{l}\text { Jameco } \\
\text { aquifer }\end{array}$ & $\begin{array}{l}\text { Jameco } \\
\text { Gravel }\end{array}$ & 200 & $\begin{array}{l}\text { Mainly medium to coarse sand of } \\
\text { moderate to high permeability. }\end{array}$ \\
\hline $\begin{array}{l}\text { Magothy } \\
\text { aquifer }\end{array}$ & $\begin{array}{l}\text { Matawan Group } \\
\text { and Magothy(?) } \\
\text { Formation } \\
\text { undifferentiated }\end{array}$ & 1,000 & $\begin{array}{l}\text { Coarse to fine sand of moderate } \\
\text { permability; locally contains } \\
\text { gravel of high permeability, } \\
\text { and abundant silt and clay of } \\
\text { low to very low permeability. }\end{array}$ \\
\hline $\begin{array}{l}\text { Raritan } \\
\text { clay }\end{array}$ & $\begin{array}{l}\text { Clay member } \\
\text { of the Raritan } \\
\text { Formation }\end{array}$ & 300 & $\begin{array}{l}\text { Clay of very low permeability; } \\
\text { some silt and fine sand of low } \\
\text { permeability. }\end{array}$ \\
\hline $\begin{array}{l}\text { Lloyd } \\
\text { aquifer }\end{array}$ & $\begin{array}{l}\text { Lloyd Sand } \\
\text { Member of } \\
\text { the Rartitan } \\
\text { Formation }\end{array}$ & 300 & $\begin{array}{l}\text { Sand and gravel of moderate } \\
\text { permeability; some clayey } \\
\text { material of low permeability. }\end{array}$ \\
\hline
\end{tabular}

Surficial deposits on Long Island are the result of the Wisconsin glaciation. Two terminal moraines form east-west-trending lines of hills of poorly sorted glacial debris that reach a maximum altitude of $400 \mathrm{ft}$. These moraines merge in the western part of the island (fig. 1). A gently sloping outwash plain composed of well-sorted glaciofluvial sand and gravel extends southward from the line of moraines to the south shore with a slope of about $20 \mathrm{ft} / \mathrm{mi}$ (Cohen and others, 1968). Small patches of poorly sorted till occur sporadically and form localized spots of relative impermeability (Seaburn and Aronson, 1974). The headlands along the north shore consist mainly of glacial deposits eroded by streams and waves to produce several embayments. The south shore is lined with swamp and marsh deposits. Barrier islands, composed mainly of sand transported and deposited by littoral currents, enclose the shallow saltwater bays.

\section{Precipitation}

Mean annual precipitation on Long Island ranges from slightly less than 41 inches on the south shore of Nassau County to slightly more than 50 inches in the island's central region (Miller and Frederick, 1969), with a long-term 
mean of 44 inches islandwide (Cohen and others, 1968). Annual precipitation during 1980, 1981, and 1982 was below average, at 40.4, 38.5, and 40.5 inches, respectively. Average warm-season and cool-season precipitation rates are almost equal.

\section{Streamflow}

The stream valleys on Long Island are broad, straight, and shallow and follow the courses established by meltwater channels during glacial retreat. The south-flowing streams are widely spaced with few or no tributaries and have gentle gradients that average $10 \mathrm{ft} / \mathrm{mi}$. The north-flowing streams generally have steeper gradients that average 20 to $40 \mathrm{ft} / \mathrm{mi}$.

The high permeability of the outwash sand and gravel, as well as the flat terrain, enable precipitation to infiltrate almost immediately. Before urbanization, about 95 percent of total streamflow consisted of water from the upper glacial aquifer (Franke and McClymonds, 1972); the remaining 5 percent consisted of direct runoff. Thus, the streams function as ground-water drains, and streamflow during dry weather is controlled directly by groundwater levels adjacent to the stream channel (Pluhowski and Kantrowitz, 1964). The reduction in recharge due to increased impermeable area and the use of sewers has lowered ground-water levels, which has in turn significantly reduced the ground-water contribution to streamflow in Nassau County (Simmons and Reynolds, 1982).

\section{Ground Water}

\section{Movement}

The ground-water system of Long Island consists of four major aquifers (table 1). The lower three are confined (artesian); the water-table (upper glacial) aquifer is hydraulically connected to the streams and lakes of the island. The water-table aquifer is no longer extensively used for publicwater supply in Nassau County because it has become contaminated from surface sources such as fertilizers and from septic-tank and cesspool discharges.

Some of the precipitation that reaches the water table moves horizontally within the upper glacial aquifer; the rest moves downward toward the underlying aquifers. Ground water north of the ground-water divide (fig. 1) flows north toward Long Island Sound; south of the divide, the general path of ground-water movement is southward. Contaminants that enter the ground water also follow these flow paths.

Where stream channels intersect the water table, they receive groundwater seepage that sustains base flow during dry weather. The remainder of the ground water discharges of fshore as subsea outflow into the Sound, the bays bordering the island, or the ocean.

\section{Recharge}

Under natural (predevelopment) conditions, about 50 percent of the average annual precipitation on Long Island infiltrated the soil and recharged the ground-water reservoir (Aronson and Seaburn, 1974); the rest was lost 
through evapotranspiration or became runoff. Now, however, much of the precipitation falls on impervious surfaces and becomes runoff, decreasing the amount of natural recharge. Today most recharge results from infiltration of precipitation through remaining pervious areas, such as lawns and other open spaces, and by infiltration of storm runoff through recharge basins.

Additional recharge results from the recycling of water used for domestic and industrial purposes through cesspools, septic tanks, leaching basins, and recharge wells, and by the infiltration of some of the water used to irrigate lawns.

More than 10 percent of the area in Nassau and Suffolk Counties drains to recharge basins. In these areas, ground-water recharge from precipitation equals or slightly exceeds recharge under predevelopment conditions because evapotranspiration is reduced (Aronson and Seaburn, 1974).

\section{URBAN HYDROLOGY OF LONG ISLAND}

\section{Population}

From the end of World War II to the late 1950's, the population of Nassau County increased rapidly (fig. 4). This wave of urbanization, characterized mainly by the construction of large developments of single-family houses, expanded eastward and, by the late 1950's, had reached Suffolk County. The population of western Suffolk County then began to increase markedly and has continued to increase more rapidly than that of any other area on Long Island.

Since the 1970 's, the rate of population increase on Long Island has slowed considerably, and the combined population of Nassau and Suffolk Counties now approaches a stable 2.7 million (U.S. Bureau of the Census, 1982).

\section{Figure 4.}

Population of Nassau and Suffolk Counties, Long Island, N.Y., 1920-80. (Data from U.S. Bureau of the Census, 1982.)

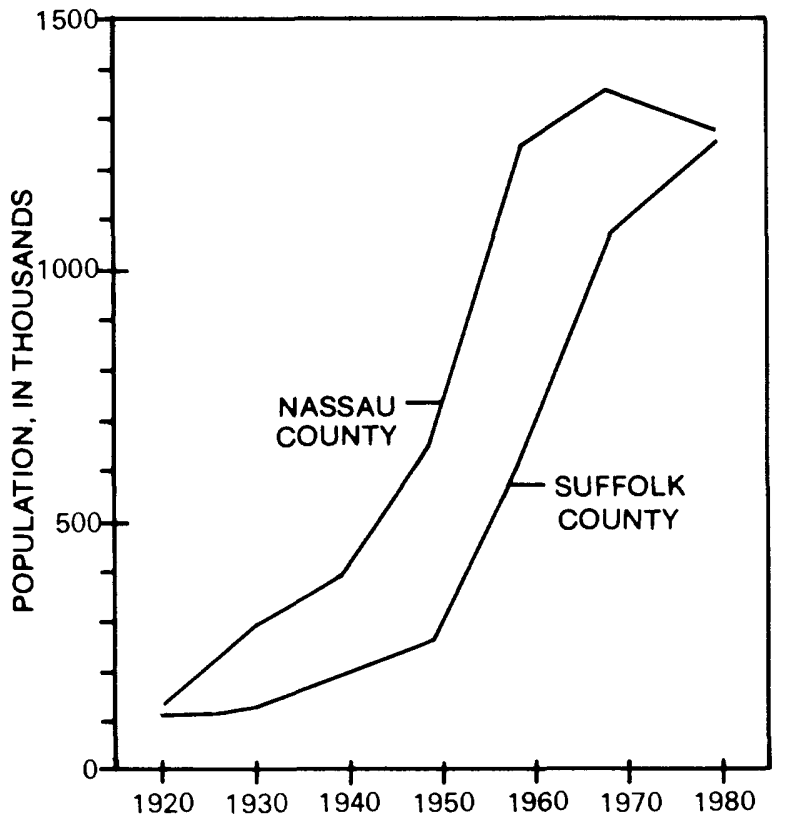




\section{Sewerage History and Plans}

Sewers in Nassau and Suffolk Counties consist of two distinct systems-sanitary sewers and storm sewers. Storm sewers consist of short sewerlines that direct stormwater runoff to the nearest stream, bay, or recharge basin. Sanitary sewers convey wastewater from residences and commercial and industrial facilities to sewage-treatment plants and carry treated effluent to the ocean. In Nassau County, the sanitary-sewer system is divided into two major sewer districts, each with its own treatment plant. Suffolk County has one sewer district, which is in the southwestern corner of the county.

\section{Sanitary Sewers}

Before Long Island's first large-scale sewage-treatment plant (in southwestern Nassau County) began operation in 1953, domestic and industrial waste was discharged into the ground from individual systems, except in the villages of Hempstead, Garden City, Rockville Centre, and Mineola, which had their own sewage systems. Yet, even these plants discharged effluent into the ground. The village of Freeport had the only sewage system that discharged its effluent to tidewater.

As of 1977, the sewage-treatment plant in southwestern Nassau County served an area of $70 \mathrm{mi}^{2}$ and a population of 580,000 ( $\mathrm{Ku}$ and Sulam, 1979). Hookups to this system were completed in 1964; about $60 \mathrm{Mgal} / \mathrm{d}$ of sewage are now treated here and discharged to tidewater.

Initial planning for sewers in southeastern Nassau County began in 1964 in response to (1) increasing commercial and industrial development, (2) the need to protect the ground-water reservoir from further contamination, and (3) the failure of aging private sewage-disposal units. The treatment plant in southeastern Nassau County is an activated-sludge type with an average design flow of $45 \mathrm{Mgal} / \mathrm{d}$; it will serve a population of approximately 500,000 . Effluent from this plant is discharged to the ocean.

The percentage of Nassau County's population served by sanitary sewers increased from 8 percent in 1940 to 54 percent in 1970; after completion of sanitary-sewer installation in southeastern Nassau County, approximately 98 percent of the county's population will be served by sanitary sewers.

The sewage-treatment plant in southwestern Suffolk County began operation in 1981. It has a capacity of $30 \mathrm{Mgal} / \mathrm{d}$ and serves a population of approximately 280,000 .

\section{Storm Sewers and Recharge Basins}

Shallow stormwater-collection basins, known as recharge basins, were constructed in Nassau County beginning in 1935 (Pluhowski and Spine11o, 1978). The conveyance of storm runoff to these basins through storm sewers enabled efficient disposal of storm runoff and replenishment of the ground water. 
Most of the recharge basins on Long Island are unlined open pits ranging in size from 0.1 to 30 acres, with an average of 1.5 acres. Most are about 10 $\mathrm{ft}$ deep, but some are as deep as $40 \mathrm{ft}$ (Seaburn and Aronson, 1973). Long Island today has more than 3,000 such basins, mainly in eastern Nassau County and western Suffolk County, near the ground-water divide (fig. 1). According to Aronson and Seaburn (1974), 91 percent of these basins are dry within 5 days after a 1-inch rainfal1. Those that hold water for longer periods do so either because they intersect the regional or a perched water table, are excavated in till or moraine of low hydraulic conductivity rather than in outwash deposits, or are clogged by sediment and debris.

Since the early 1960 's, many storm sewers have been constructed in southern Nassau County and southwestern Suffolk County, where the population increase has been rapid (P1uhowski and Spine11o, 1978). Here, however, the water table is less than $20 \mathrm{ft}$ below land surface (Koszalka, 1975), which makes the excavation of recharge basins impractical. Therefore, most of the storm runoff in this area is conveyed directly to streams, which in turn discharge to the south-shore bays.

\section{DESCRIPTION OF MONITORING SITES}

Five recharge basins--three in Nassau County and two in Suffolk County (fig. 2)--were chosen for study by the U.S. Geological Survey on the basis of the type of land use in the area from which they receive stormwater runoff. The five basins together represent a wide variety of land uses. The physical characteristics of these recharge basins and their drainage areas are described below and are summarized in table 2 (p. 22); a map and aerial photograph of each area are shown in figures $5 \mathrm{~A}-5 \mathrm{E}$.

\section{Centereach (Commercial)}

The recharge basin at Centereach (fig. 5A) receives storm runoff from a four-lane asphalt State highway that is bordered on both sides by small commercial establishments. Although the topographic drainage area includes 553 acres, the area served by storm sewers that lead to the basin, as determined by the New York State Department of Transportation (DOT), which owns and maintains the basin, is only 69 acres. Of this effective drainage area, 5.8 acres are impervious and consist of the State highway, driveways, and side-road intersections. Topographic relief in the drainage area is about 10 feet.

The basin floor occupies about 0.5 acres and is underlain by sand and grave1. This basin was constructed in 1977 and was designated Ecological Recharge Basin $\left.\right|_{2}$ by the New York State DOT. The basin bottom was lined with 30-mil polyvinylchloride sheets so that it retains water and has formed an artificial pond. The pond is stocked by DOT with fish and aquatic vegetation. Beneath the impermeable liner is an exfiltration system consisting of perforated pipes. When the pond level rises, the excess water flows through a filter box into the exfiltration system and ultimately recharges the ground water. 


\section{Huntington (Shopping Center and Parking Lot)}

The recharge basin at Huntington (privately owned, fig. 5B) receives runoff from 35 acres of a large shopping center and the adjacent parking lot. The parking lot is paved with asphalt and is curbed. The basin floor occupies about 0.5 acres and is underlain by sand and grave1. Vegetation in this basin is sparser than in the others, and consists mainly of grass and weeds. Topographic relief in the drainage area is near zero.

Most recharge basins on Long Island do not hold water longer than 5 days after a storm. However, those that drain parking areas tend to become clogged with oil and rubber and asphalt particles and therefore contain water most, if not all, the time. Although the basin at Huntington is clogged, ponded stormwater infiltrates through the basin walls above the impermeable part and allows as much runoff to infiltrate as in a basin that is not clogged, although more slowly, owing to the reduced infiltration area.

\section{Laurel Hollow (Low-Density Residential)}

The recharge basin at Laurel Hollow (fig. 5C) drains approximately 100 acres of low-density residential area. Within this area, newly constructed one-family houses occupy lots of one or more acres. This basin was constructed in 1979. It contains 1ittle vegetation and is underlain by sand and grave1. The basin floor occupies 0.6 acres.

Roads in the drainage area are two lanes wide, paved with asphalt, and curbed in most places. Topographic relief is $160 \mathrm{feet}$, which is the greatest relief of the five drainage basins studied.

\section{Plainview (Highway)}

The recharge basin at Plainview (fig. 5D), constructed in 1956, receives runoff from the Long Island Expressway and its service road. Of the 190 acres of topographic drainage area, 12 acres form the contributing area, which consists of a six-lane concrete highway, two-lane asphalt service roads, and a few driveways. The highway is curbed on both sides; the service road is not. Topographic rellef in the drainage area is 60 feet.

The basin floor occupies approximately 1 acre. It is underlain by sand and grave 1 and is covered by thick vegetation including grass, weeds, bushes, and trees.

\section{Syosset (Medium-Density Residential)}

The recharge basin at Syosset (fig. 5E) drains approximately 28 acres of medium-density residential area containing single-family houses on quarteracre lots. The basin was constructed in 1957. Its floor occupies 0.3 acres and is underlain by sand and grave1. The basin contains thick vegetation, including grass, weeds, bushes, and some trees.

Roads in the drainage area are two lanes wide, paved with asphalt, and curbed. Topographic relief within the drainage area is less than $20 \mathrm{feet}$. 
$40^{\circ} 51^{\prime} 30^{\prime \prime}$

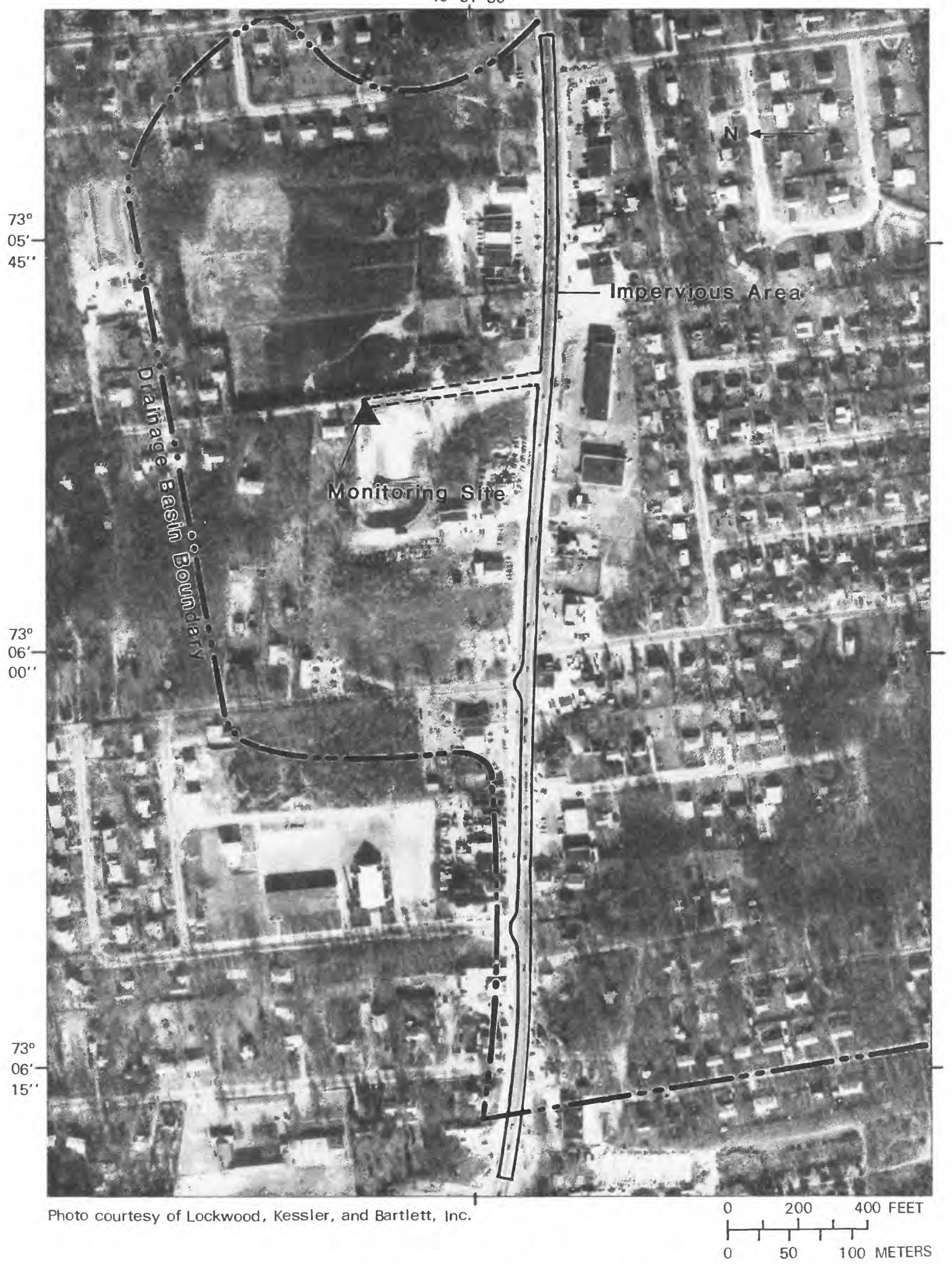

Figure 5A.--Aerial photograph and map of drainage area 


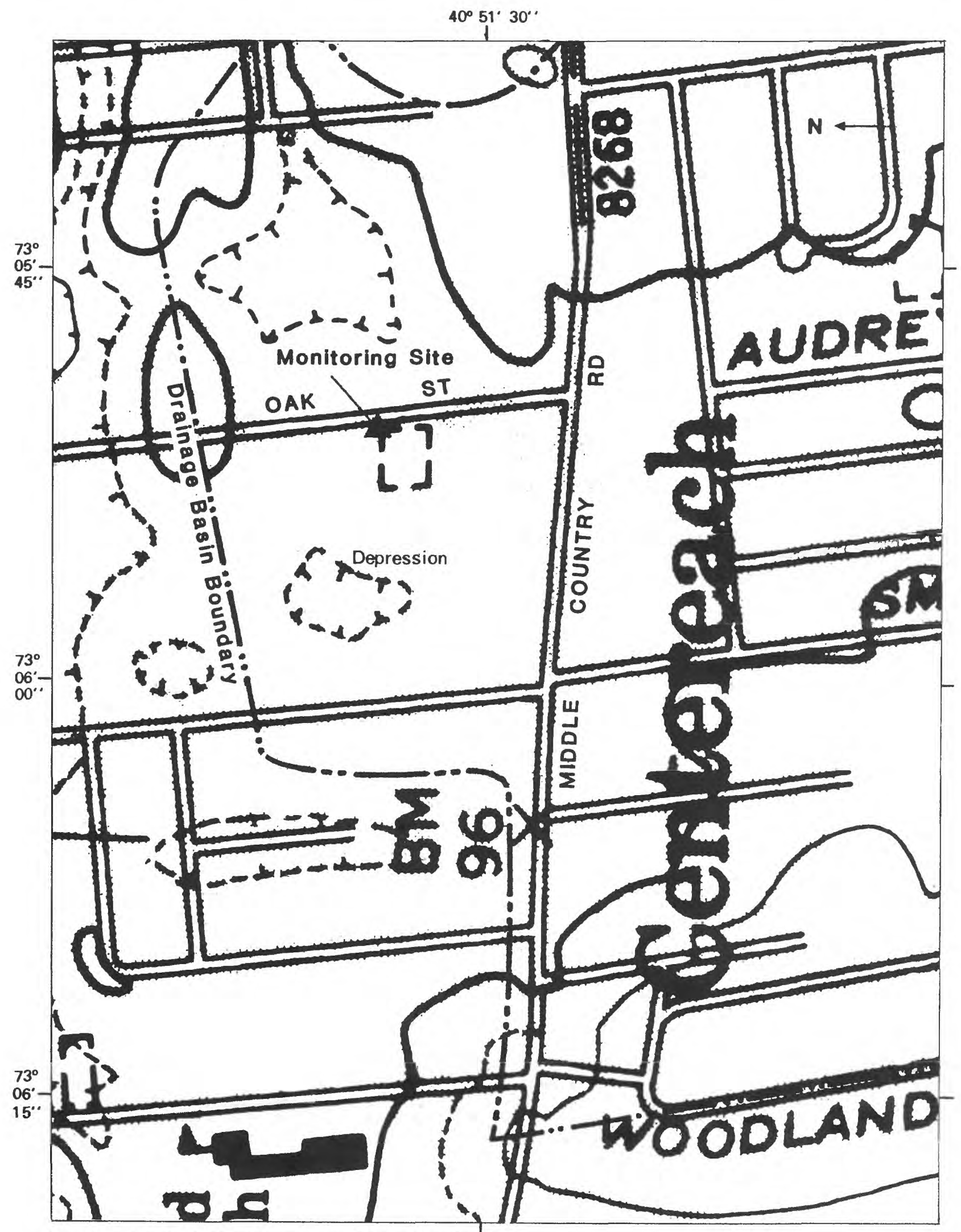

Base from New York State Department of Transportation,

Centereach, N.Y., 1:24,000, 1981

at Centereach. (Location is shown in fig. 2.)

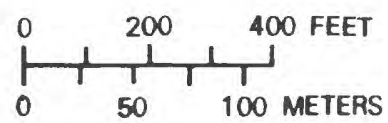




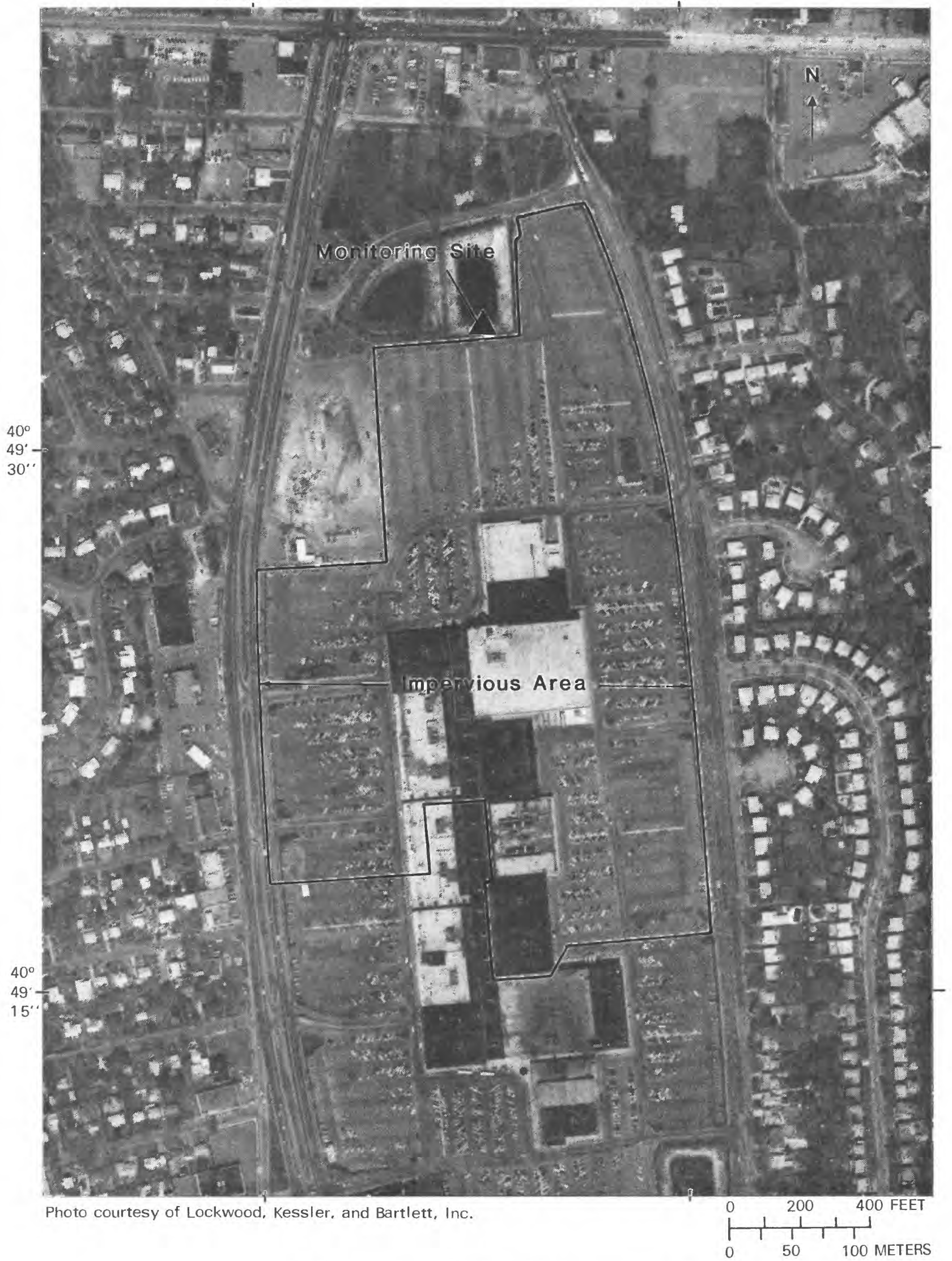

Figure 5B.--Aerial photograph and map of drainage area 


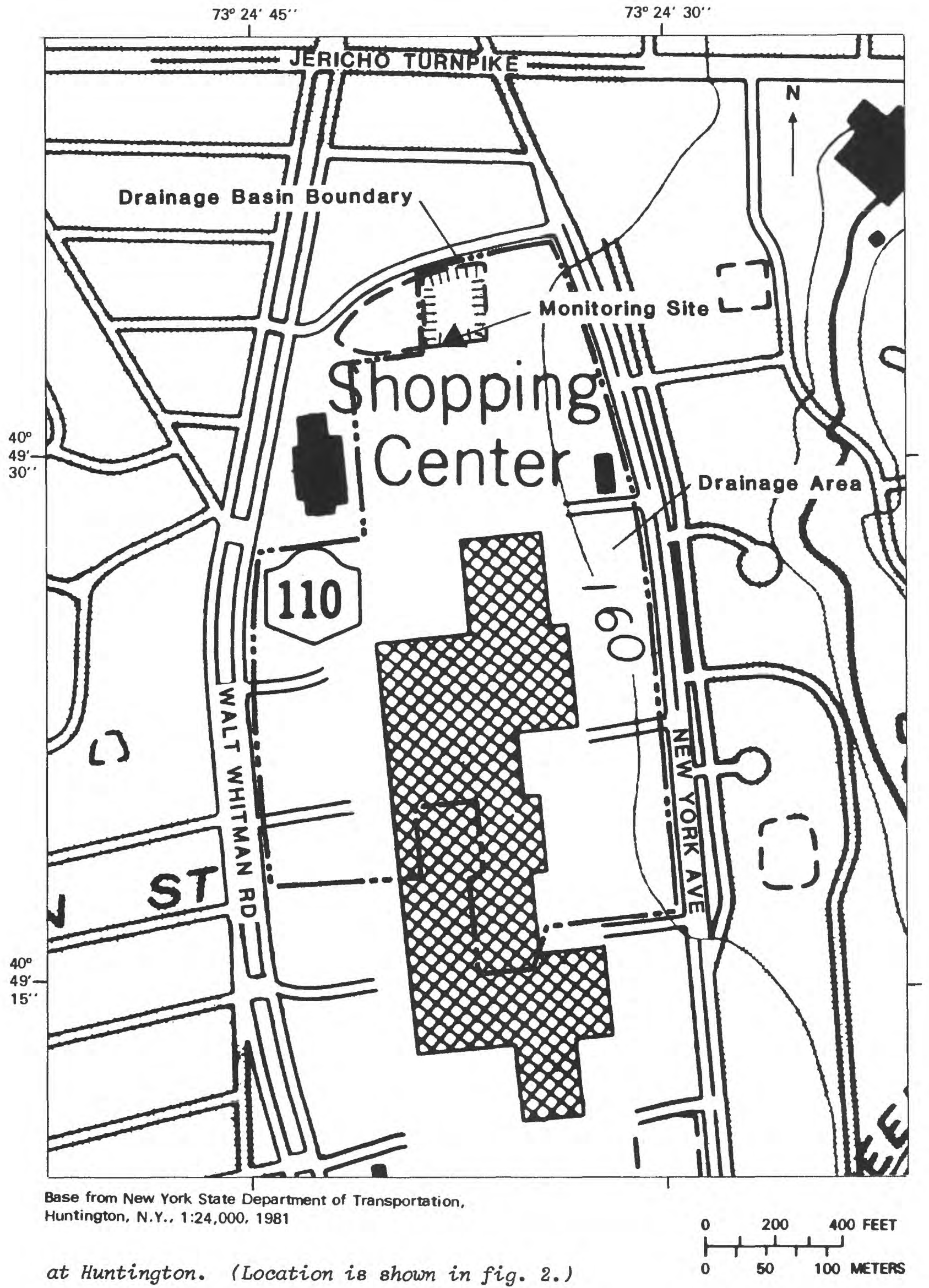




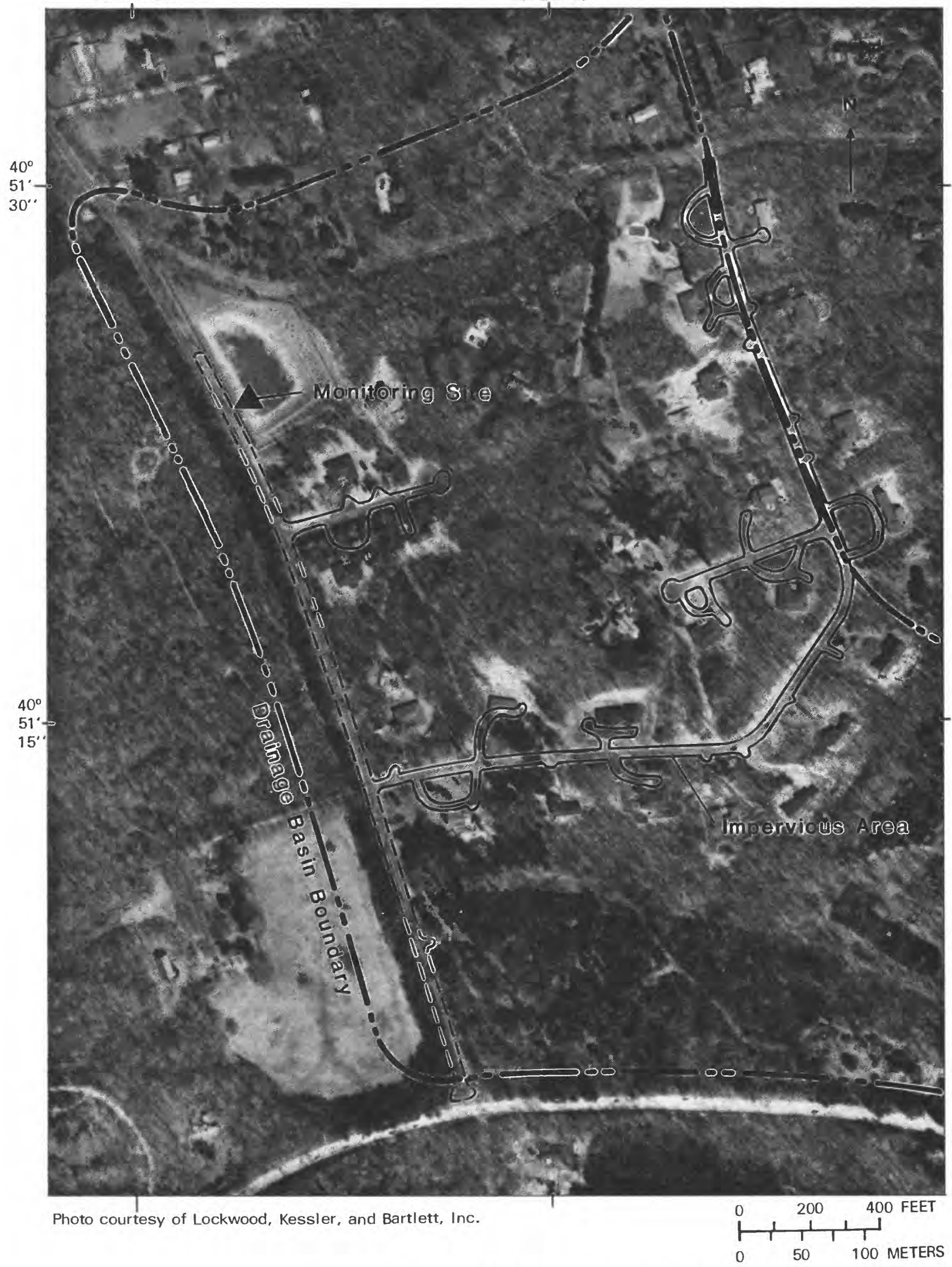

Figure 5C.--Aerial photograph and map of drainage area 


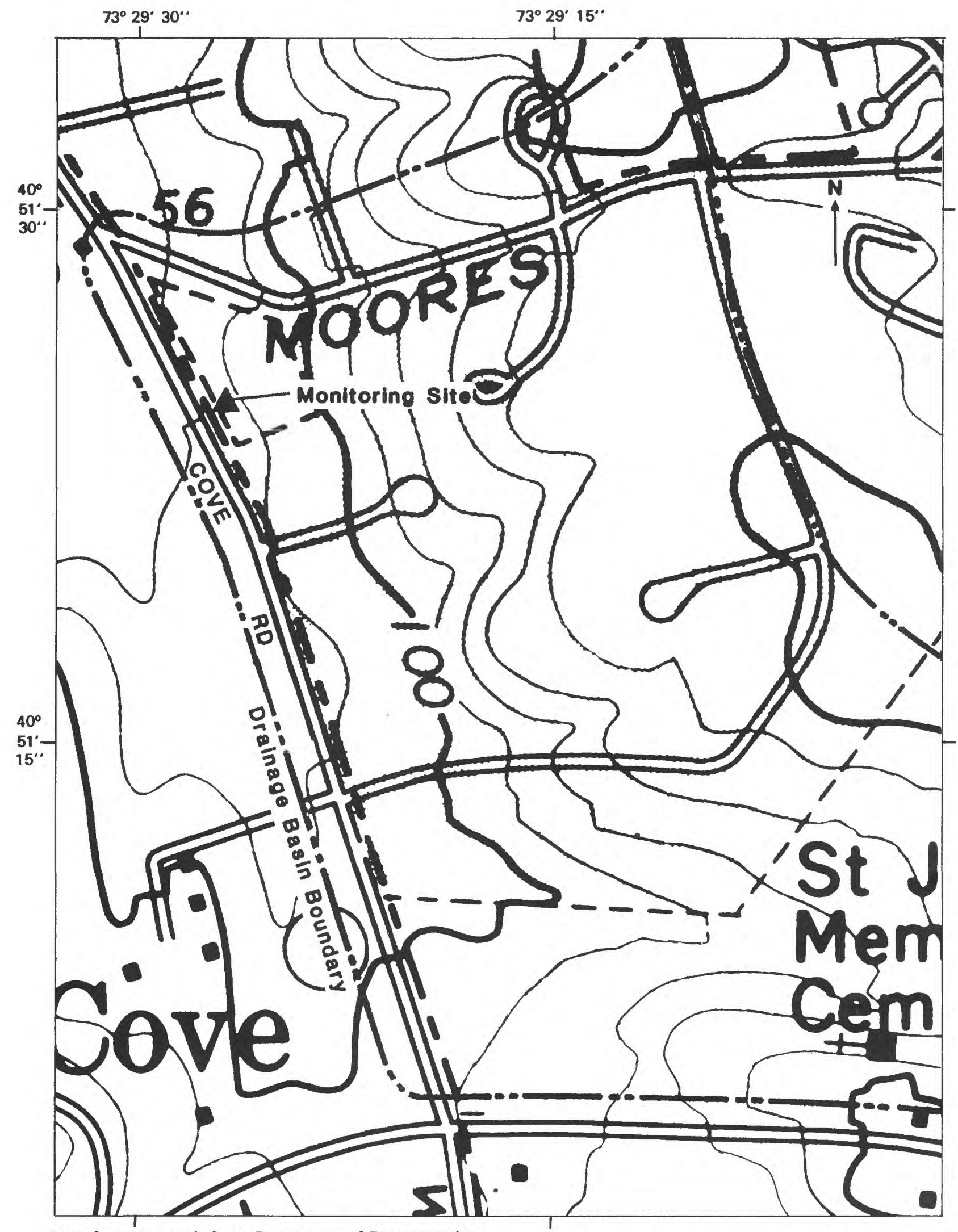

Base from New York State Department of Transportation,
Laurel Hollow, N.Y., 1:24,000, 1981
at Laurel Hollow. (Location is shown in fig. 2.)

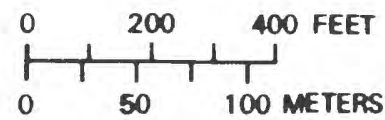


$73^{\circ} 27^{\prime} 30^{\prime \prime}$

$73^{\circ} 27^{\prime} 15^{\prime \prime}$

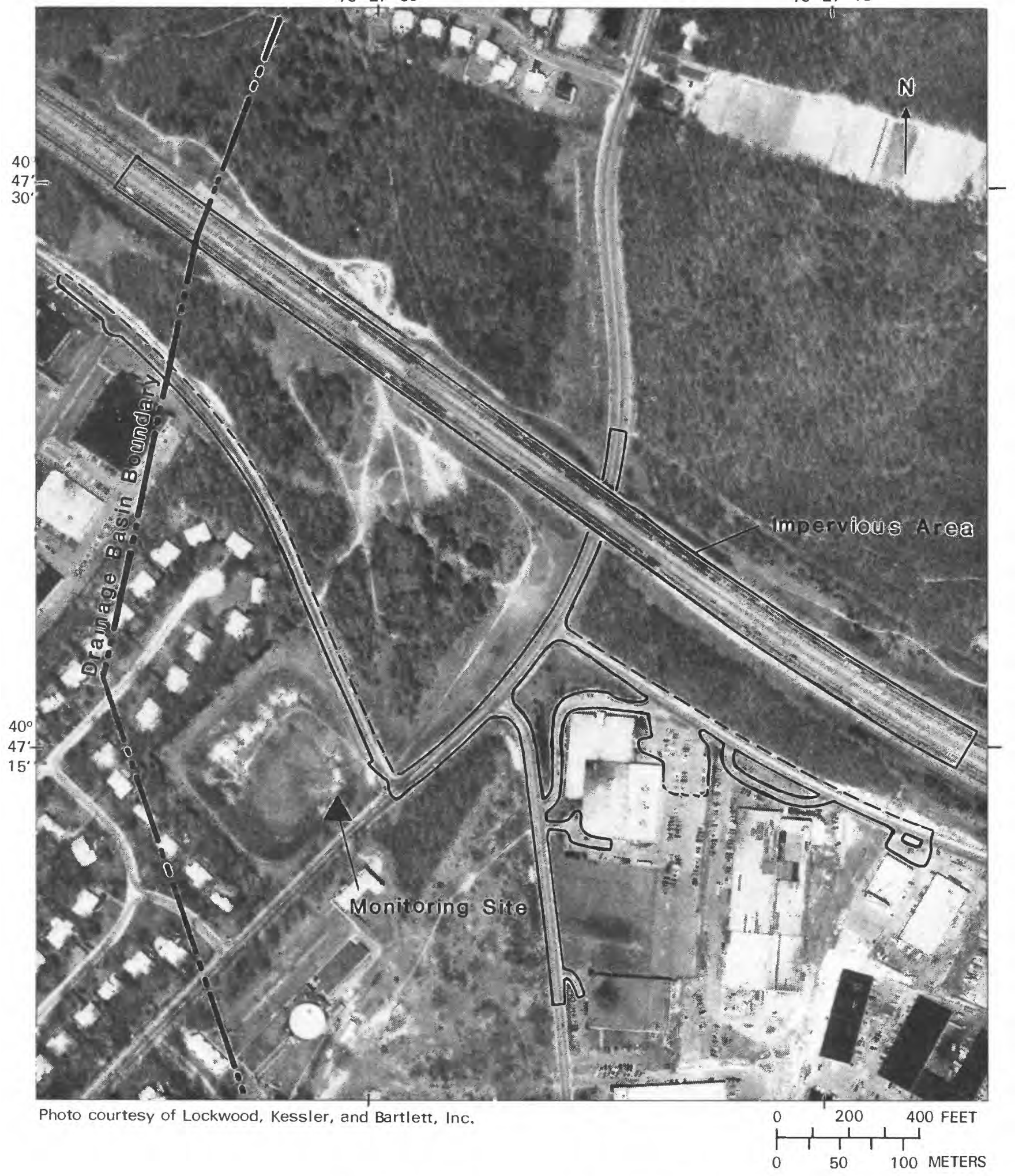

Figure 5D.--Aerial photograph and map of drainage area 


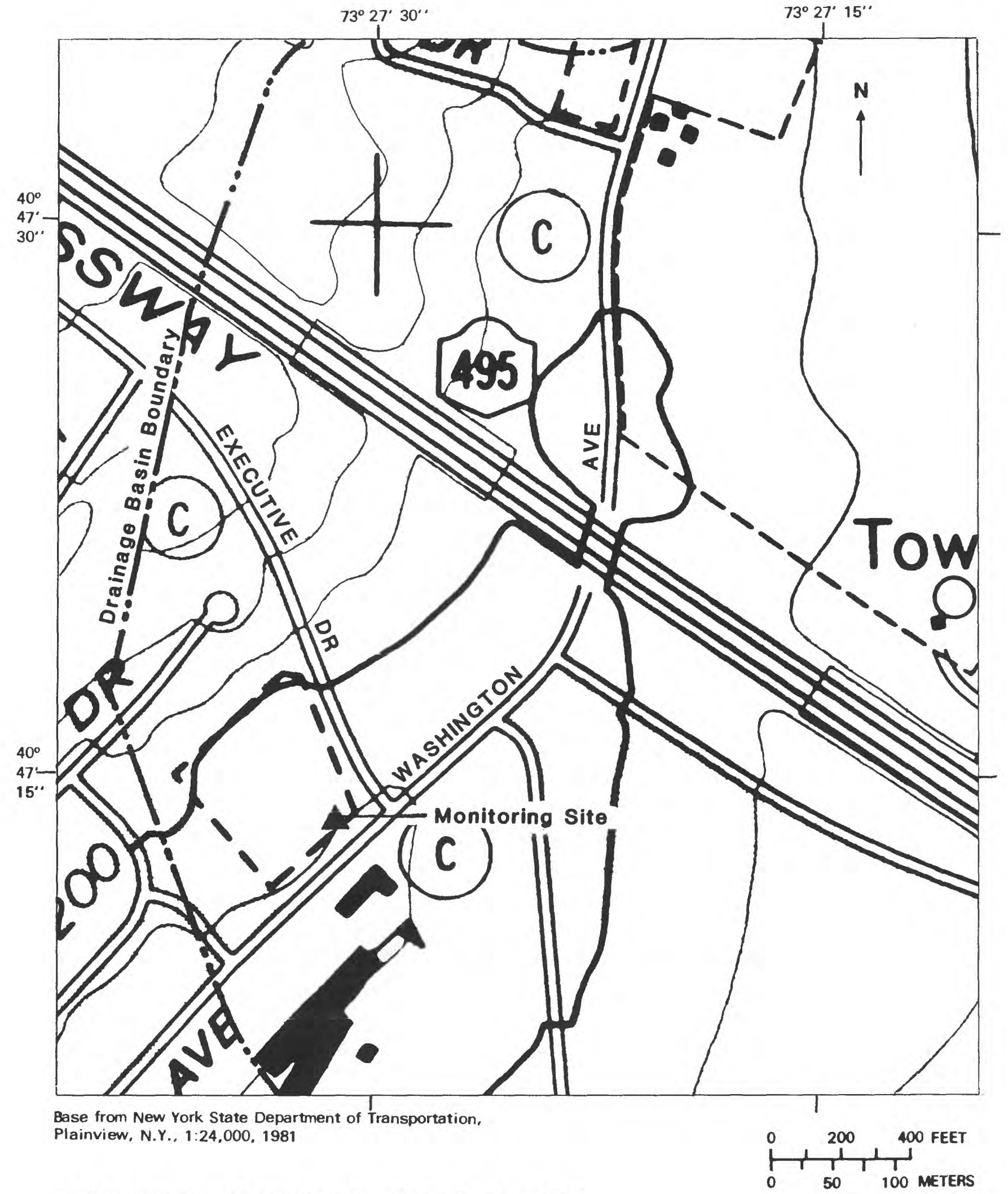

at Plainview. (Location is shown in fig. 2.) 


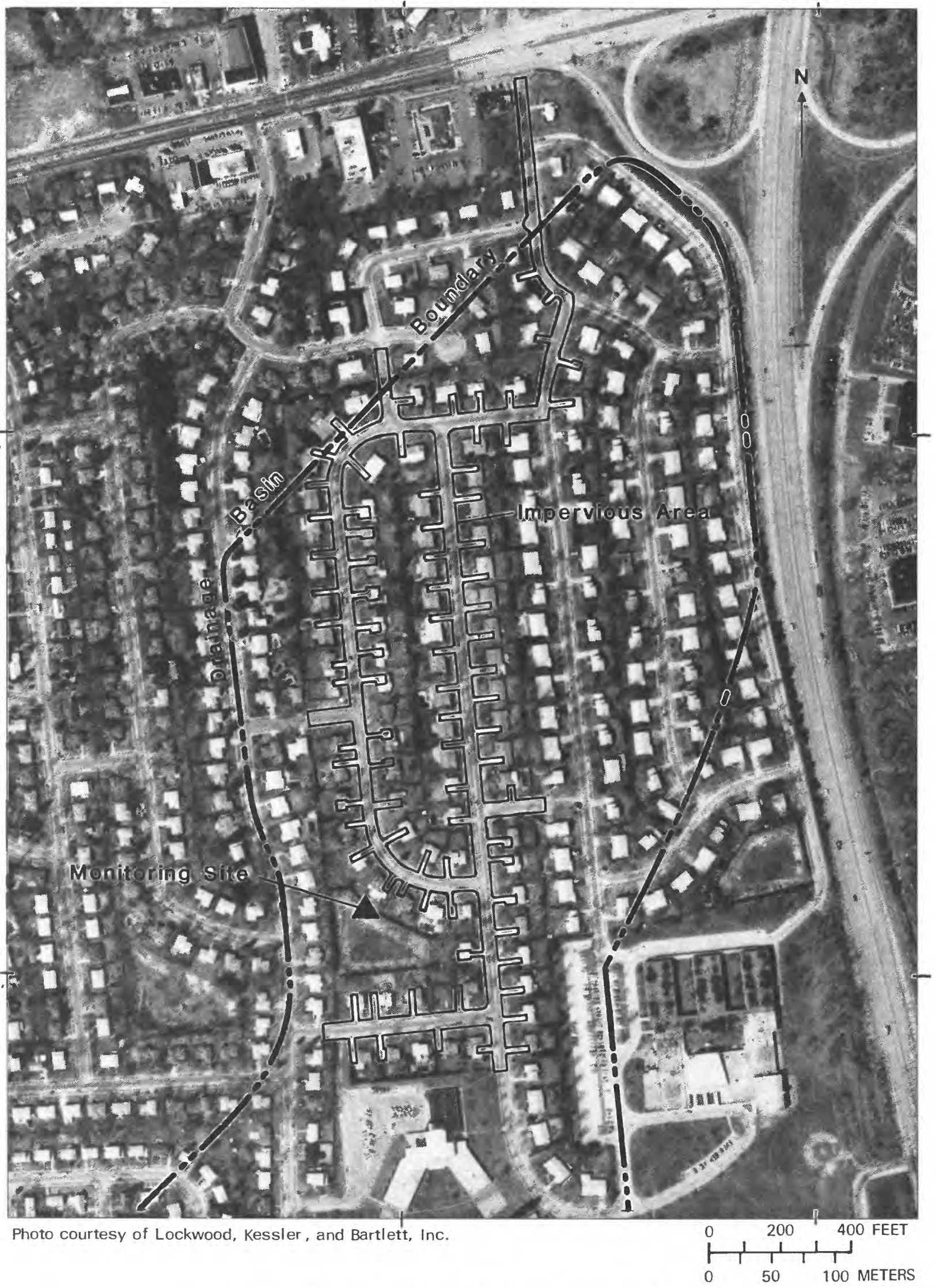

Figure 5E.--Aerial photograph and map of drainage area 


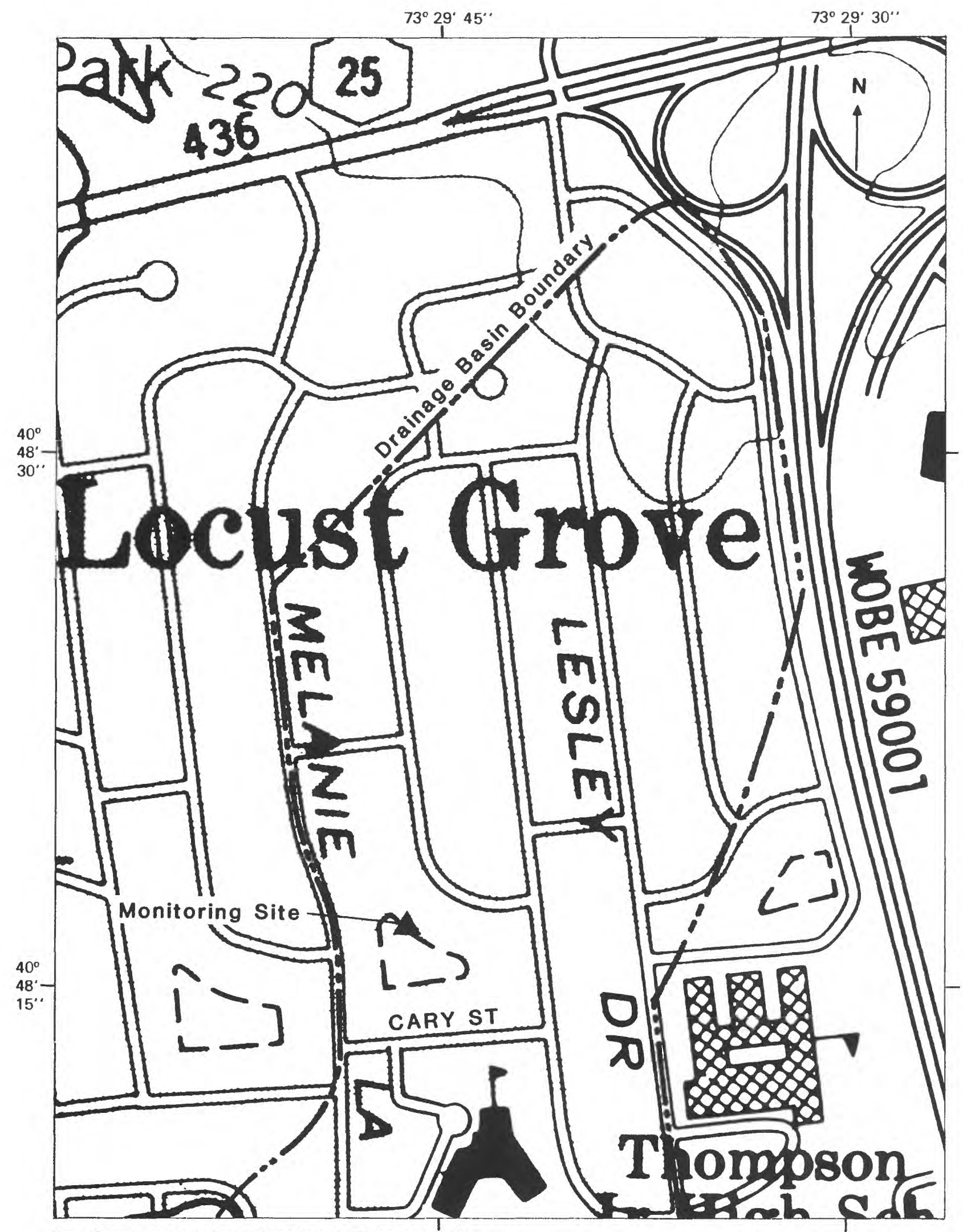

Base from New York State Department of Transportation,

Syosset, N.Y., 1:24,000, 1981

at Syosset. (Location is shown in fig. 2.)

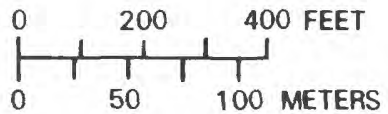


Table 2.--Physical characteristics of recharge basins studied.

[Photographs and maps of drainage areas are given in figs. 5A-5E.]

\begin{tabular}{|c|c|c|c|c|c|c|c|}
\hline \multirow{3}{*}{$\begin{array}{c}\text { Site } \\
\text { location } \\
\text { and local } \\
\text { basin } \\
\text { number }\end{array}$} & \multirow[b]{3}{*}{ Land use } & \multicolumn{3}{|c|}{ Dralnage area } & \multirow[b]{3}{*}{$\begin{array}{l}\text { Soll } \\
\text { type } 1\end{array}$} & \multirow{3}{*}{$\begin{array}{l}\text { Approximate } \\
\text { depth to } \\
\text { water table } \\
\text { (ft) }\end{array}$} & \multirow[b]{3}{*}{ Remarks } \\
\hline & & \multirow[b]{2}{*}{$\begin{array}{r}\text { Total } \\
\text { (acres) }\end{array}$} & \multicolumn{2}{|c|}{ Impervious area } & & & \\
\hline & & & (acres) & (percent) & & & \\
\hline $\begin{array}{l}\text { Centereach } \\
\text { NYSDOT- } \\
\text { ERB2 } 2\end{array}$ & $\begin{array}{l}\text { Strip } \\
\text { commercial }\end{array}$ & 69 & 5.8 & 7.1 & Dukes sand & 39 & $\begin{array}{l}\text { Constructed with lmper- } \\
\text { vious liner to hold } \\
\text { water at all times }\end{array}$ \\
\hline $\begin{array}{l}\text { Huntington } \\
\text { private }\end{array}$ & $\begin{array}{l}\text { Shopping ma11, } \\
\text { parking lot }\end{array}$ & 35 & 35 & 100 & $\begin{array}{l}\text { Sassafrass } \\
\text { loam }\end{array}$ & 66 & Always contalns water \\
\hline $\begin{array}{l}\text { Laurel } \\
\text { Hollow } \\
\text { NCDPW-566 }\end{array}$ & $\begin{array}{l}\text { Low density } \\
\text { resident } 1 \text { al } 4\end{array}$ & 100 & 4.7 & 4.7 & Haven loam & 22 & $\begin{array}{l}\text { Basin is newly con- } \\
\text { structed }(1979)\end{array}$ \\
\hline $\begin{array}{l}\text { Plainview } \\
\text { NYSDOT- } 66\end{array}$ & $\begin{array}{l}\text { Major } \\
\text { highway }\end{array}$ & 190 & 12 & 6.3 & Haven loam & 58 & $\begin{array}{l}\text { Heavy vegetation in } \\
\text { basin }\end{array}$ \\
\hline $\begin{array}{l}\text { Syosset } \\
\text { NCDPW-377 }\end{array}$ & $\begin{array}{l}\text { Medium } \\
\text { density } \\
\text { resident } 1 a^{5}\end{array}$ & 28 & 6.3 & 23 & $\begin{array}{l}\text { Hempstead } \\
\text { loam }\end{array}$ & 78 & $\begin{array}{l}\text { Heavy vegetation in } \\
\text { basin }\end{array}$ \\
\hline $\begin{array}{l}1 \text { Classific } \\
2 \text { New York } \\
3 \text { Nassau Co }\end{array}$ & $\begin{array}{l}\text { ation from Loun } \\
\text { State Departmen } \\
\text { unty Department }\end{array}$ & $\begin{array}{l}\text { sbury and } \\
\text { of Trar } \\
\text { of Publ1 }\end{array}$ & $\begin{array}{l}\text { d others } \\
\text { nsportat: } \\
\text { 1c Works }\end{array}$ & $\begin{array}{l}(1928) \\
\text { Ion }\end{array}$ & & $\begin{array}{l}4 \text { 1-acre zc } \\
5 \text { 1/4-acre }\end{array}$ & $\begin{array}{l}\text { ning } \\
\text { zoning }\end{array}$ \\
\hline
\end{tabular}

\section{SAMPLE COLLECTION AND DATA MANAGEMENT}

This study was designed to collect a large quantity of storm-related data to define the type and quantity of contaminants in stormwater runoff and their effect on the quality of ground water beneath Long Island's recharge basins. The five recharge basins were instrumented to collect samples of precipitation, stormwater inflow into the basins, and stormwater that had infiltrated the basin floor and the unsaturated zone to become ground water.

\section{Sampling Equipment}

A schematic diagram of the instrumentation at each of the five sites is shown in figure 6 .

\section{Precipitation Measurement}

Precipitation was measured by a tipping-bucket rain gage manufactured by Weathertronics, Inc.1, and recorded on 16-channel digital tape at 5-minute intervals by a Stevens recorder. Precipitation was collected in a large, plastic-lined bucket placed outside the instrument housing for the duration of

T Use of brand names is for identification only and does not imply endorsement by the U.S. Geological Survey. 
the storm. In this way, information on precipitation quantity, quality, and intensity was collected during each storm.

Figure 6.

Schematic diagram of instrumentation at each recharge basin.

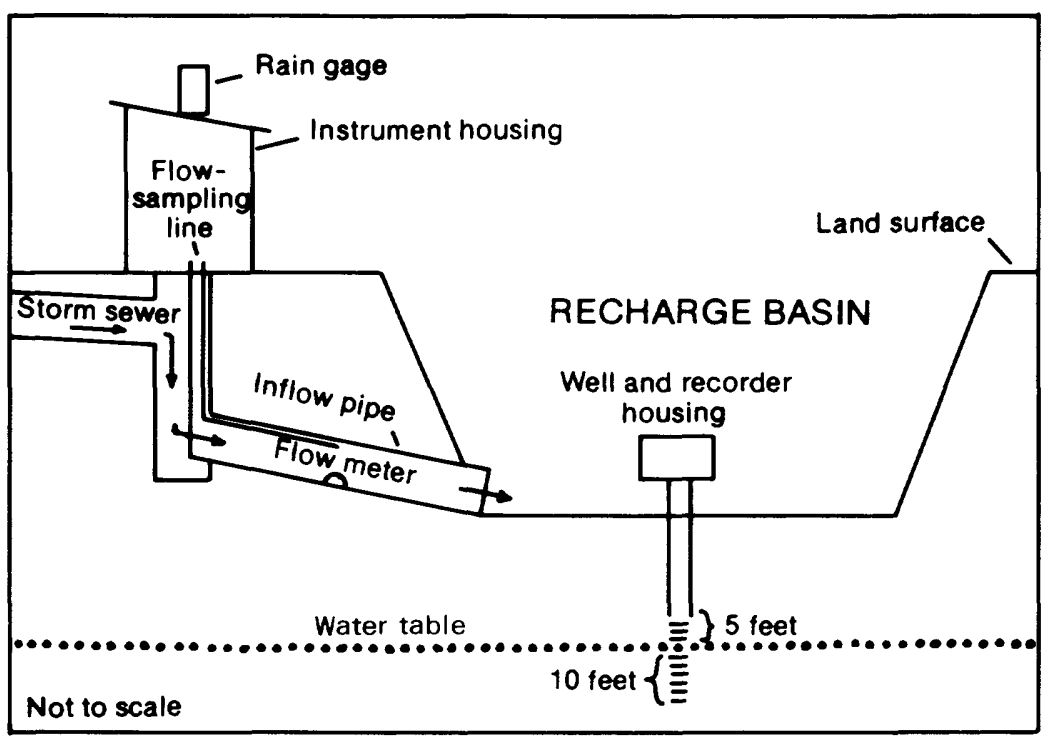

\section{Stormwater and Ground-Water Measurement}

The quantity of stormwater inflow to the recharge basins was measured with a Marsh-McBirney velocity-modified flow meter, model 250, and was recorded on 16-channel paper tape at 5-minute intervals by a Stevens digital recorder. The flow rate was also recorded on a 7-day circular chart that is an integral part of the flow meter. Both devices record flow as a percentage of a user-determined maximum.

Stormwater was sampled from the storm-sewer line by a Manning S-6000 stationary discrete sampler. This sampler draws 1 liter of water through a vacuum line and discharges it into bottles in an attached refrigerated compartment. The sampler can be programmed to collect samples automatically at predetermined volume or time intervals, or it can be activated manually. This equipment allowed for the collection of data on total flow volume, flow rate, and stormwater quality.

A well in or adjacent to each recharge basin was equipped with a Stevens Type $F$ water-level recorder that indicated when the stormwater reached the water table. Subsequent pumping and (or) bailing of the well provided samples for water-quality analysis.

Flow-meter calibration.--The flow meter is factory-calibrated for flow velocities up to $20 \mathrm{ft} / \mathrm{s}$. The performance of each flow meter was fieldcalibrated against discharge measurements determined by the dye-dilution method described by Cobb and Balley (1965). The dye used was rhodamine WT. Discharge can be computed from the following equation:

$$
Q=\frac{C_{1}-c_{2}}{c_{2}-c_{b}} q
$$


where: $Q$ is discharge of stream,

$\mathrm{q}$ is rate of flow of injected dye solution,

$\mathrm{C}_{\mathrm{b}}$ is background concentration of dye in the stream,

$\mathrm{C}_{1}$ is dye concentration of the solution injected into the stream, and

$\mathrm{C}_{2}$ is measured concentration of dye in stream water during injection.

The flow meters at all basins but Huntington were calibrated. The Huntington basin, adjacent to a shopping center, is clogged and always contains water. Because the outfall pipe is always submerged, collection of dye samples at the outlet is impossible. For this reason, as well as the associated reverse flow within the pipe, this flow meter was not calibrated, and the discharges recorded at the Huntington site are assumed to be inaccurate and lower than the actual discharges.

Comparison of discharge-measurement results.--A comparison of discharge measurements made by dye-dilution methods with those made by the flow meter is given in table 3 and figure 7 . The correlation coefficient relating all
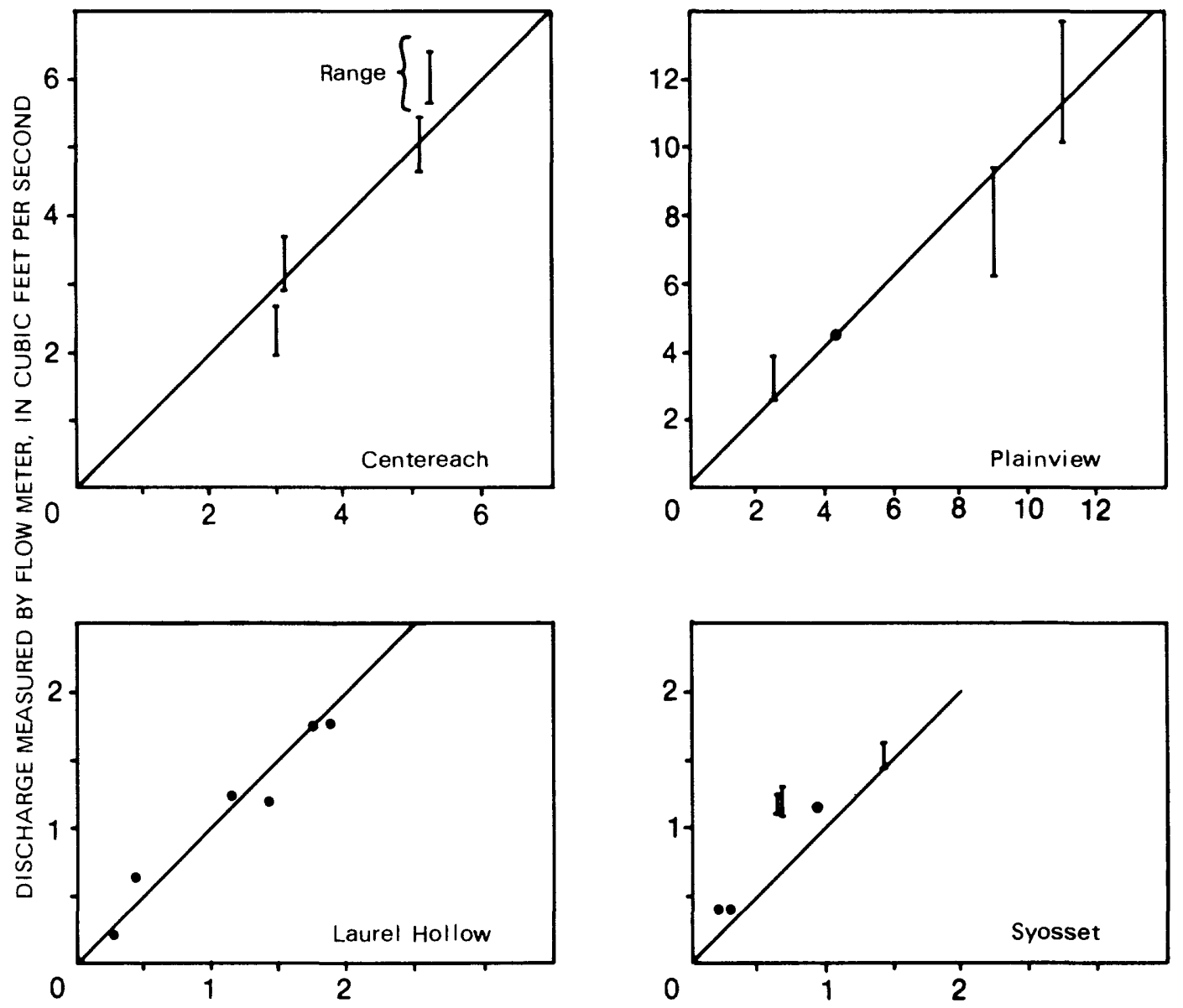

DISCHARGE MEASURED BY DYE-DILUTION METHOD, IN CUBIC FEET PER SECOND

Figure 7.--Relationship between discharge measured simultaneously by flow meter and by dye-dilution method at Centereach, Plainview, Laurel Hollow, and Syosset. (The $45^{\circ}$ line through origin represents points at which measurements by both methods would be equal.) Explanation of ranges is given in table 3 , footnote 1 . 
discharge measurements obtained by dye dilution with the closer flow-meter discharge measurements is 0.997 ; the correlation coefficient relating dye-dilution measurements with the other flow-meter discharge measurements is 0.968. Correlation coefficients for each individual flow meter, although not statistically significant owing to the small number ( 4 to 6 ) of data points, range from 0.932 (Syosset) to 0.999 (Plainview) for the closer measurements, and from 0.843 (Centereach) to 0.920 (Syosset) for the other measurements.

Although the maximum recorded discharge at each site was greater than the maximum discharge for which the flow meter was calibrated, the plots in figure 7 show a general linearity in the relationship between results of the two measurement methods. The scatter of data points is probably due to a combination of rapid flow fluctuations and the delayed response of the flow meter to changes in flow velocity.

Table 3.--Comparison of flow measurements recorded by flow meter with measurements obtained by dye-dilution methods.

[Site locations are shown in fig. 2.]

\begin{tabular}{|c|c|c|c|}
\hline \multirow[b]{3}{*}{ Basin } & \multicolumn{3}{|c|}{ Stormwater Inflow $\left(\mathrm{ft}^{3} / \mathrm{s}\right)$} \\
\hline & \multicolumn{2}{|c|}{ Flow meter } & \multirow[b]{2}{*}{ Dye dilution } \\
\hline & Start & Finish & \\
\hline Centereach 1 & $\begin{array}{l}5.77 \\
4.60 \\
3.08 \\
1.92\end{array}$ & $\begin{array}{l}6.55 \\
5.40 \\
3.85 \\
2.69\end{array}$ & $\begin{array}{l}5.23 \\
5.10 \\
3.11 \\
3.00\end{array}$ \\
\hline Huntington ${ }^{2}$ & - & -- & -- \\
\hline Laurel Hollow & -- & $\begin{array}{l}1.76 \\
1.69 \\
1.26 \\
1.32 \\
0.73 \\
0.22\end{array}$ & $\begin{array}{l}1.79 \\
1.67 \\
1.45 \\
1.20 \\
0.43 \\
0.25\end{array}$ \\
\hline Plainview ${ }^{1}$ & $\begin{array}{c}10.8 \\
6.19 \\
4.64 \\
2.63\end{array}$ & $\begin{array}{c}13.9 \\
9.28 \\
4.64 \\
3.87\end{array}$ & $\begin{array}{r}11.2 \\
9.10 \\
4.57 \\
2.52\end{array}$ \\
\hline Syosset ${ }^{1}$ & $\begin{array}{l}1.08 \\
1.46 \\
1.10\end{array}$ & $\begin{array}{l}0.39 \\
1.23 \\
0.39 \\
1.62 \\
1.15 \\
1.20\end{array}$ & $\begin{array}{l}0.29 \\
0.69 \\
0.24 \\
1.45 \\
0.93 \\
0.68\end{array}$ \\
\hline
\end{tabular}

1 Sampling at these sites of ten requires several minutes; therefore, discharge measurements recorded by the flow meter at both the start and the end of the dye sampling are listed.

2 Dye samples cannot be collected at this basin because it always contains water, and the outflow pipe is constantly submerged. 
Because the correlation coefficient between the discharge measurements obtained from the flow meter and from dye dilution is high, and because the relationship appears (from the limited number of data points) to be linear, the discharge measurements recorded by the flow meter are used in this report without correction.

\section{Sample Collection}

Stormwater and ground-water samples were collected for analysis for chemical, bacterial, and organic constituents. Constituents included in standard chemical analysis are listed in appendix $A$; the compounds included in the category of "priority pollutants" are listed in appendix B.

\section{Standard Chemicals}

The general procedure for collecting stormwater samples for standard chemical analysis was to collect the first sample when flow first appeared in the sewerline and registered on the circular flow chart and to collect subsequent samples at 10-, 20-, 30-, and 60-minute intervals. Hourly samples were collected thereafter when the flow was continuous. During intermittent flow, an attempt was made to collect samples near hydrograph peaks.

Sampling-well screens were positioned one-third above and two-thirds below the water table. One or two days after each storm, when the infiltrated runof $f$ had produced a water-table mound, ground-water samples were collected from the top of the mound, just beneath the water table, with a submersible pump. The well casing was evacuated a minimum of three times before sampling.

\section{Priority Polzutants}

One stormwater and two ground-water samples were collected at each site (except Centereach) for analysis for 113 of the 129 organic compounds designated "priority pollutants" by the U.S. Environmental Protection Agency. At Centereach, one stormwater sample and one ground-water sample were collected.

The stormwater samples were collected manually in a stainless-steel vessel and were poured into l-liter pretreated glass bottles with Teflon seals. One 1-liter grab sample was collected for every 2,000 gal of stormwater inflow. Therefore, the first $32,000 \mathrm{gal}$ of stormwater runof $f$ into the basins were represented by a sample of 16 liters. One 1-liter, flow-weighted composite stormwater sample was prepared from the 16 grab samples.

Runof $f$ in excess of 32,000 gal was not sampled because stormwater constituent concentrations are generally highest near the beginning of a storm (Wanielista, 1978, p. 240). Sampling in this way produces priority-pollutant constituent concentrations that are adequately representative of the storm, but may err on the conservative (high) side.

Samples of ground water were collected on arbitrarily selected days unrelated to particular storms to obtain information on background levels of priority pollutants. The well casing was evacuated a minimum of three times 
with a submersible pump before sampling. Samples to be analyzed for volatile organic compounds were collected in a $40-\mathrm{mL}$ glass vial with a Teflon seal. Other ground-water samples were collected in l-liter pretreated glass bottles with Teflon seals.

The stormwater sample was sent as a flow-weighted composite; the ground-water sample was a grab sample. These were packaged and preserved as recommended by the U.S. Envi ronmental Protection Agency (Versar, 1980).

\section{Bacteria}

Stormwater samples to be analyzed for bacteria we re collected on the same schedule as outlined above for standard chemical analysis but were collected manually in sterile bottles. They were delivered to the appropriate laboratory as described below within hours after the cessation of flow. Groundwater samples to be analyzed for bacteria (total coliforms, fecal coliforms, and fecal streptococc1) we re collected 1 or 2 days after the rainfall after the well casing had been evacuated a minimum of three times and after all other samples were collected.

\section{Sample Handling}

\section{Standard Chemicals}

Samples collected for standard chemical analysis (appendix A) were kept chilled at all times, including transport from the field to the laboratory. Each 1-liter sample was split into 10 parts, from which the analyses were performed. Split samples were packed with ice and sent to the U.S. Geological Survey Laboratory in Doraville, Ga., for analysis.

\section{Priority Pollutants}

Ground-water and stormwater samples collected for priority pollutant analysis (appendix B) were sent overnight to one of several laboratories across the United States approved by the USEPA for analysis for organic compounds. Stormwater-runoff samples were submitted as flow-weighted composites. Samples were collected and preserved in accordance with guidelines defined by the USEPA (Versar, 1980).

\section{Bacteria}

Bacteria samples were kept chilled in the field and during transport to the Nassau County Health Department Laboratory, where they were analyzed for total coliform, fecal coliform, and fecal streptococci bacteria within 24 hours of collection.

\section{Data Reduction}

Discharge and precipitation data recorded on 16-channel digital tape were reduced to an individual hydrograph and hyetograph for each storm through a BASIC computer program written for a Tektronix 4051 graphic system. 
Discharge was graphed in 5-minute increments, while rainfall was graphed in 15-minute increments. The program also calculated total rainfall, total runoff volume, and the runoff volume associated with each stormwater-quality sample.

\section{Data Storage}

Each sampling site was assigned a station-identification number consisting of 15 digits. The first 13 digits represent the latitude and longitude of the sampling location; the last two digits, also called the sequence number, indicate the type of sample collected, such as stormwater, precipitation, or ground water. All data pertaining to stormwater at a given site, whether flow or water quality, use the same station number.

All data are stored in the U.S. Geological Survey National Water Data Storage and Retrieval System (WATSTORE) and in the U.S. Environmental Protection Agency Computerized Storage and Retrieval of Water Quality Data System (STORET). They can be retrieved from either system through the station numbers listed in appendix $C$.

\section{CHARACTERISTICS OF SAMPLED STORMS}

A total of 46 storms was sampled at the five recharge basins. The choice of storms was based on seasonal distribution and an attempt to sample storms of varying intensity and duration.

Table 4 shows the number of storms sampled at each site during each season. Fewer storms were sampled during summer because thunderstorms are typically difficult to predict and are often of short duration.

Characteristics of each storm are summarized in table 5. These include precipitation duration, total precipitation, maximum intensity (maximum precipitation during a 15-minute period), total runoff, and number of antecedent dry days. (A dry day is defined as a day with less than 0.1 inches of precipitation.)

The storms sampled differed widely in duration and total precipitation. Duration ranged from 2 hours to 26 hours; precipitation ranged from 0.20 inches to 4.84 inches. Other storms during the study were of shorter duration

Table 4.--Number of storms sampled per site, by season, 1980-82. [Locations are shown in fig. 2]

\begin{tabular}{|c|c|c|c|c|c|c|}
\hline \multirow[b]{2}{*}{ Season } & \multicolumn{5}{|c|}{ Site } & \multirow[b]{2}{*}{ Tota } \\
\hline & Centereach & Huntingt on & $\begin{array}{l}\text { Laurel } \\
\text { Hollow }\end{array}$ & Plainview & Syosset & \\
\hline autumn & 0 & 2 & 3 & 5 & 3 & 13 \\
\hline winter & 2 & 4 & 3 & 4 & 0 & 13 \\
\hline spring & 4 & 5 & 2 & 0 & 3 & 14 \\
\hline summe r & $\underline{0}$ & 1 & $\underline{1}$ & $\underline{1}$ & $\underline{3}$ & $\underline{6}$ \\
\hline Total & $\overline{6}$ & $1 \overline{2}$ & $\overline{9}$ & $1 \overline{0}$ & $\overline{9}$ & $4 \overline{6}$ \\
\hline
\end{tabular}


Table 5.--Characteristics of sampled storms, 1980-82. [Locations are shown in fig. 2]

\begin{tabular}{|c|c|c|c|c|c|c|}
\hline Date & S1te & $\begin{array}{l}\text { Duration } \\
\text { (hours) }\end{array}$ & $\begin{array}{l}\text { Precipi- } \\
\text { tation } \\
\text { (1n) }\end{array}$ & $\begin{array}{c}\text { Maximum } \\
\text { Intensity } \\
(\text { In/15 min) }\end{array}$ & $\begin{array}{r}\text { Tota1 } \\
\text { runoff } \\
\left(f t^{3}\right) \\
\end{array}$ & $\begin{array}{l}\text { Number of } \\
\text { antecedent } \\
\text { dry days } \\
(<0.1 \text { in })\end{array}$ \\
\hline $9-18-80$ & $\begin{array}{l}\text { Plainview } \\
\text { Huntington }\end{array}$ & $\begin{array}{l}7 \\
7\end{array}$ & $\begin{array}{r}0.64 \\
.59\end{array}$ & $\begin{array}{r}0.12 \\
.08\end{array}$ & $\begin{array}{r}1,390 \\
c_{3,330}\end{array}$ & $\begin{array}{l}2 \\
2\end{array}$ \\
\hline $10-25-80$ & $\begin{array}{l}\text { Syosset } \\
\text { Huntington } \\
\text { Plainview }\end{array}$ & $\begin{array}{l}7 \\
9 \\
8\end{array}$ & $\begin{array}{l}1.67 \\
1.36 \\
1.51\end{array}$ & $\begin{array}{r}.12 \\
.12 \\
.11\end{array}$ & $\begin{array}{c}12,300 \\
a_{-} \\
27,600\end{array}$ & $\begin{array}{l}5 \\
5 \\
5\end{array}$ \\
\hline $11-18-80$ & $\begin{array}{l}\text { Laurel Hollow } \\
\text { Plainview }\end{array}$ & $\begin{array}{l}7 \\
7\end{array}$ & $\begin{array}{l}.93 \\
.78\end{array}$ & $\begin{array}{l}.09 \\
.08\end{array}$ & $\begin{array}{r}2,140 \\
21,800\end{array}$ & $\begin{array}{l}7 \\
7\end{array}$ \\
\hline $11-24-80$ & $\begin{array}{l}\text { Laurel Hollow } \\
\text { Plainview }\end{array}$ & $\begin{array}{l}11 \\
11\end{array}$ & $\begin{array}{l}1.48 \\
1.37\end{array}$ & $\begin{array}{l}.33 \\
.17\end{array}$ & $\begin{array}{r}7,570 \\
55,100\end{array}$ & $\begin{array}{l}5 \\
5\end{array}$ \\
\hline $12-9-80$ & $\begin{array}{l}\text { Laurel Hollow } \\
\text { Plainview }\end{array}$ & $\begin{array}{l}6 \\
6\end{array}$ & $\begin{array}{l}.20 \\
.20\end{array}$ & $\begin{array}{l}.04 \\
.04\end{array}$ & $\begin{array}{l}121 \\
112\end{array}$ & $\begin{array}{l}1 \\
1\end{array}$ \\
\hline $12-30-80$ & Plainviewa & -- & -- & -- & -- & 1 \\
\hline $2-1-81$ & $\begin{array}{l}\text { Laurel Hollow } \\
\text { Plainview }\end{array}$ & $\begin{array}{r}18 \\
6\end{array}$ & $\begin{array}{l}.85 \\
.75\end{array}$ & $\begin{array}{l}.06 \\
.06\end{array}$ & $\begin{array}{r}6,070 \\
26,500\end{array}$ & $\begin{array}{l}14 \\
14\end{array}$ \\
\hline $2-11-81$ & Plainview & 7 & .52 & .23 & 28,300 & 2 \\
\hline $2-19-81$ & $\begin{array}{l}\text { Hunt ington } \\
\text { Laurel Hollow }\end{array}$ & $\begin{array}{l}22 \\
22\end{array}$ & $\begin{array}{l}1.49 \\
1.80\end{array}$ & $\begin{array}{l}.15 \\
.06\end{array}$ & $\begin{array}{r}c_{17,200} \\
10,300\end{array}$ & $\begin{array}{l}6 \\
6\end{array}$ \\
\hline $2-23-81$ & $\begin{array}{l}\text { Huntington } \\
\text { Laurel Hollow }\end{array}$ & $\begin{array}{l}7 \\
8\end{array}$ & $\begin{array}{l}.75 \\
.82\end{array}$ & $\begin{array}{l}.05 \\
.13\end{array}$ & $\begin{array}{r}6,860 \\
3,940\end{array}$ & $\begin{array}{l}1 \\
1\end{array}$ \\
\hline $3-30-81$ & $\begin{array}{l}\text { Huntington } \\
\text { Laurel Hollow }\end{array}$ & $\begin{array}{l}6 \\
6\end{array}$ & $\begin{array}{r}.49 \\
.40\end{array}$ & .04 & $\begin{array}{r}9,230 \\
1,000\end{array}$ & $\begin{array}{l}12 \\
12\end{array}$ \\
\hline $4-14-81$ & $\begin{array}{l}\text { Huntington } \\
\text { Syosset }\end{array}$ & $\begin{array}{l}8 \\
9\end{array}$ & $\begin{array}{r}\mathrm{b}_{1} .03 \\
1.04\end{array}$ & .09 & $\begin{array}{r}4,610 \\
10,400\end{array}$ & $\begin{array}{l}4 \\
4\end{array}$ \\
\hline $4-23-81$ & $\begin{array}{l}\text { Huntington } \\
\text { Syosset }\end{array}$ & $\begin{array}{l}4 \\
8\end{array}$ & $\begin{array}{r}.73 \\
.98\end{array}$ & $\begin{array}{l}.32 \\
.32\end{array}$ & $\begin{array}{r}650 \\
9,794\end{array}$ & $\begin{array}{l}8 \\
8\end{array}$ \\
\hline $5-11-81$ & $\begin{array}{l}\text { Huntington } \\
\text { Laurel Hollow }\end{array}$ & $\begin{array}{r}\mathrm{b}_{12} \\
13\end{array}$ & $\begin{array}{r}b_{0} .27 \\
.26\end{array}$ & 0.04 & $\begin{array}{r}c_{10,500} \\
611\end{array}$ & $\begin{array}{l}6 \\
6\end{array}$ \\
\hline $5-29-81$ & $\begin{array}{l}\text { Huntington } \\
\text { Syosset }\end{array}$ & 6 & $\begin{array}{r}.86 \\
.44\end{array}$ & .15 & $\begin{array}{r}c_{21}, 900 \\
11,400\end{array}$ & $\begin{array}{l}11 \\
11\end{array}$ \\
\hline $7-3-81$ & Laurel Hollow & 2 & .88 & .26 & c 3,040 & 1 \\
\hline $7-20-81$ & $\begin{array}{l}\text { Huntington } \\
\text { Syosset }\end{array}$ & $\begin{array}{l}b_{3} \\
b_{13}\end{array}$ & $\begin{array}{l}\mathrm{b} .95 \\
\mathrm{~b} . .85\end{array}$ & & $\begin{array}{r}c_{15,400} \\
11,200\end{array}$ & $\begin{array}{l}13 \\
13\end{array}$ \\
\hline $7-29-81$ & Syosset & 2 & .18 & .09 & 1,640 & 1 \\
\hline $9-8-81$ & Plalnview & $3-c c$ & $\begin{array}{r}.69 \\
\text { tinued - }\end{array}$ & .23 & 21,800 & 7 \\
\hline
\end{tabular}


Table 5.--Characteristics of sampled storms, 1980-82.--continued

\begin{tabular}{|c|c|c|c|c|c|c|}
\hline Date & Site & $\begin{array}{l}\text { Duration } \\
\text { (hours) }\end{array}$ & $\begin{array}{l}\text { Precipi- } \\
\text { tation } \\
(1 \mathrm{n}) \\
\end{array}$ & $\begin{array}{c}\text { Maximum } \\
\text { intensity } \\
(1 \mathrm{n} / 15 \mathrm{~min}) \\
\end{array}$ & $\begin{array}{r}\text { Total } \\
\text { runof } f \\
\left(\mathrm{ft}^{3}\right) \\
\end{array}$ & $\begin{array}{l}\text { Number of } \\
\text { antecedent } \\
\text { dry days } \\
(<0.1 \text { in }) \\
\end{array}$ \\
\hline $9-15-81$ & $\begin{array}{l}\text { Huntington } \\
\text { Syosset }\end{array}$ & $\begin{array}{r}\mathrm{b}_{24} \\
26\end{array}$ & $\begin{array}{l}1.65 \\
1.77\end{array}$ & .10 & $\begin{array}{r}c_{112}, 000 \\
31,600\end{array}$ & $\begin{array}{l}6 \\
6\end{array}$ \\
\hline $12-1-81$ & Syosset & 11 & 1.12 & .12 & 33,900 & 10 \\
\hline $12-15-81$ & Syosset & 13 & 1.98 & .04 & 27,600 & 0.4 \\
\hline $1-23-82$ & Huntington & 5 & 1.33 & .18 & $c, d_{56,900}$ & \\
\hline $2-2-82$ & Plainview & 8 & 1.32 & .08 & 80,600 & 1 \\
\hline $3-4-82$ & Centereach & 5 & .84 & .12 & 27,500 & 12 \\
\hline $3-16-82$ & Centereach & 3 & .65 & .07 & 7,750 & 2 \\
\hline $4-26-82$ & Centereach & 6 & $b_{1.89}$ & & $b_{31,800}$ & 8 \\
\hline $6-1-82$ & Centereach & 4 & 1.55 & .25 & 57,700 & 2 \\
\hline $6-5-82$ & Centereach & 16 & 4.84 & .24 & 191,000 & 2 \\
\hline $6-16-82$ & Centereach & 2 & .45 & .18 & 19,100 & 1 \\
\hline
\end{tabular}

b estimated from records from nearby precipitation gages

c recorded discharges--assumed to be lower than actual discharges

d including snowmelt

and had less precipitation; these were not sampled because storms having less than 0.2 inches of continuous precipitation generally do not produce significant runoff. Because the storm characteristics differ so widely, extreme caution must be used in making comparisions between storms.

Table 6 1ists the source and number of samples collected at each site as part of the conventional (other than priority pollutant) sampling program and the type of analyses performed. A total of 750 analyses was made. Precipitation was sampled for standard chemical analysis (appendix A) during each storm at each site; stormwater runoff and ground water were sampled both for bacteria and standard chemical analysis. In addition, the pond at Centereach was sampled for bacteria several days after a storm to obtain information on the effect of pond-residence time on the bacteria count.

A separate metals analysis requested by the USEPA was done on five stormwater-runoff samples from the Huntington basin during the storm of May 11, 1981. These grab samples were analyzed for concentrations of 29 metals; the results are given in Versar, Inc. (1982).

The types of samples collected for priority-pollutant analysis are 1isted in table 7. One stormwater sample was collected at each site, and two ground-water samples were collected at each site except Centereach, where only one was obtained. 


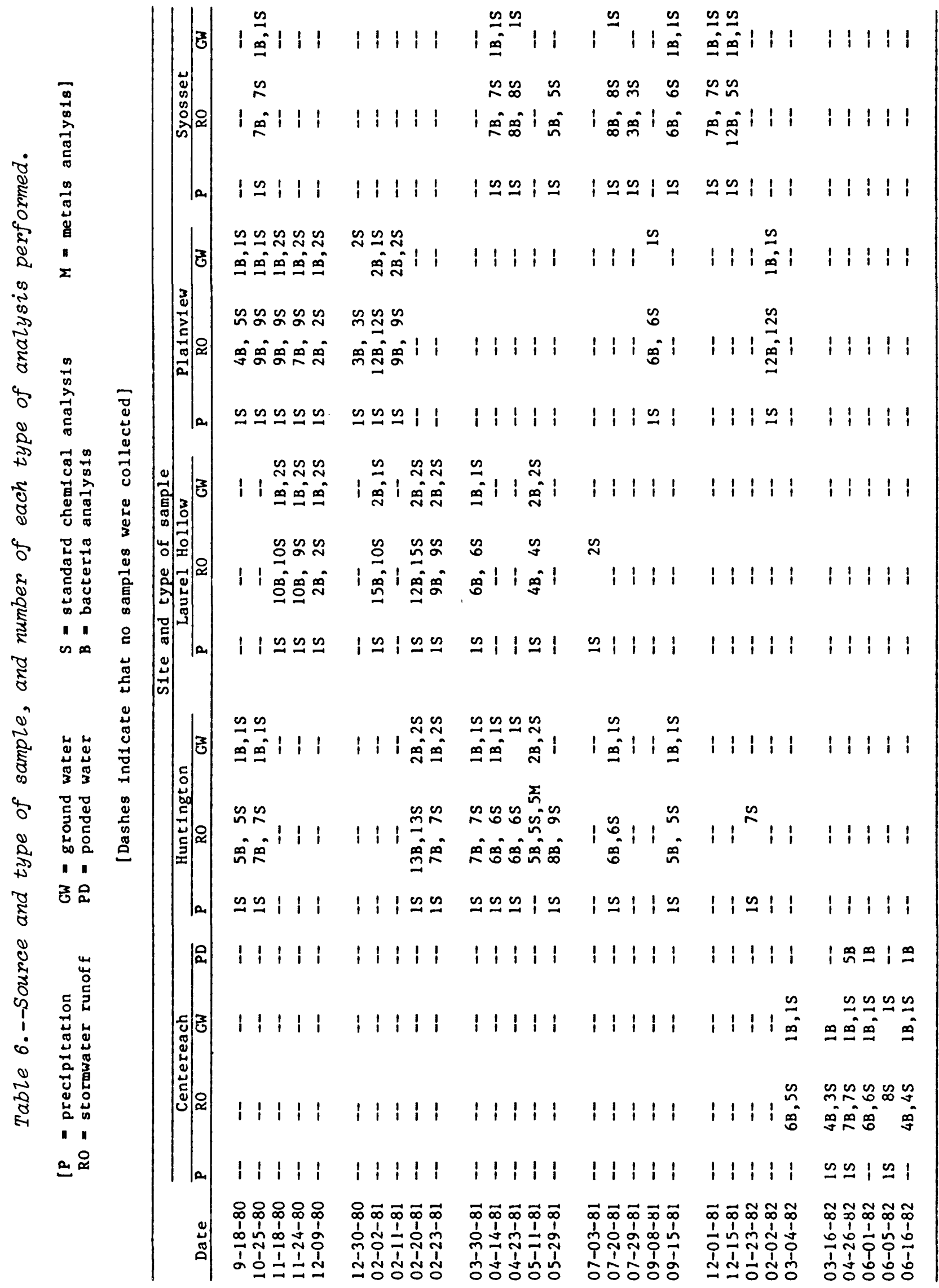


Table 7.--Source of samples collected for priority-pollutant analysis.

\begin{tabular}{|c|c|c|}
\hline Site & Date & Sample source \\
\hline Centereach & $\begin{array}{l}4-26-82 \\
4-27-82\end{array}$ & $\begin{array}{l}\text { storm water } \\
\text { ground water }\end{array}$ \\
\hline Huntington & $\begin{array}{l}3-30-81 \\
5-7-81 \\
9-28-81\end{array}$ & $\begin{array}{l}\text { storm water } \\
\text { ground water } \\
\text { ground water }\end{array}$ \\
\hline Laurel Hollow & $\begin{array}{l}3-30-81 \\
5-7-81 \\
9-28-81\end{array}$ & $\begin{array}{l}\text { storm water } \\
\text { ground water } \\
\text { ground water }\end{array}$ \\
\hline Plainview & $\begin{array}{l}2-11-81 \\
5-7-81 \\
9-28-81\end{array}$ & $\begin{array}{l}\text { storm water } \\
\text { ground water } \\
\text { ground water }\end{array}$ \\
\hline Syosset & $\begin{array}{l}4-14-81 \\
5-7-81 \\
9-28-81\end{array}$ & $\begin{array}{l}\text { storm water } \\
\text { ground water } \\
\text { ground water }\end{array}$ \\
\hline
\end{tabular}

\section{MODIFIED RUNOFF/PRECIPITATION RELATIONSHIP}

Long Island's soil in general consists of medium- to fine-grained sand and therefore has a high infiltration rate. Seaburn (1969) showed that during the predevelopment period (1937-43) at the East Meadow Brook drainage basin, in south-central Nassau County, runoff represented only 5 to 6 percent of precipitation, which indicates rapid infiltration with little or no overland runoff during most storms.

The runoff values used in computing the modified runoff/precipitation ratios for all storms at each site in this study were obtained by dividing the runoff volume by the contributing impervious-surface area to determine runof $f$, in inches. The contributing impervious surface area was used instead of the topographic area, which is normally used, because (1) the topographic drainage area does not necessarily coincide with the storm-sewer drainage network, and (2) most, if not all, runoff during a typical storm consists of precipitation falling on impervious surfaces.

The median and range of the modified runoff/precipitation ratio (based on impervious surface area) for each of the five sampling sites are given in table 8 ; the modified runoff/precipitation ratios are given in table 9 . A ratio of 100 percent or less indicates that all runof $f$ is from precipitation falling directly on impervious surfaces. A ratio greater than 100 percent indicates overland runoff from pervious surfaces as well. The median modified runoff/precipitation ratios in table 8 show that most of the runoff into the recharge basins was derived from rain falling directly on impervious surfaces. In other words, little or no overland runoff occurred during most storms. 
Table 8.--Median and runge of modified

rinoff/precipitation ratio, in percent.

\begin{tabular}{lcrr}
\hline Basin & Minimum & Median & Maximum \\
\hline Centereach & 57 & 170 & 202 \\
Huntington & $>0.7$ & $>13$ & $>53$ \\
Laurel Hollow & 14 & 25 & 42 \\
Plainview & 5 & 78 & 140 \\
Syosset & 32 & 59 & 114 \\
& & & \\
\hline
\end{tabular}

Theoretically, the Huntington site should always have a modified runoff/precipitation ratio of 100 percent because its drainage area is 100 percent impervious. Table 8 , however, shows low ratios for the Huntington basin. This is probably attributable to three factors: (1) inaccurate flow data due to reverse flow in the inflow pipe, where the electromagnetic flow sensor is located; (2) possible exfiltration of runoff through manholes and storm-sewer lines before reaching the basin; and (3) possible storage and subsequent evaporation of stormwater from depressions in the drainage area.

With the exception of the Huntington basin, the lowest modified median runoff/precipitation ratio (25) was at Laurel Hollow, the low-density residential area. At Syosset, the medium-density residential area, the ratio was higher (44), and at Plainview, the predominantly paved highway area, the ratio was still higher (69).

The strip-commercial area at Centereach has high modified runoff/ precipitation ratios, which may in part reflect unaccounted-for roof top, parking, and side-street areas that may drain into the recharge basin. In addition, three of the six storms sampled at Centereach had precipitation in excess of 1.5 inches. (See table 5 for detailed storm characteristics.) During such storms, overland runoff would be significant.

Log-log plots of precipitation against runoff at each of the five sampling sites are given in figure 8. Despite the large degree of scatter, a linear relationship is evident, which is especially close in the plots for Laurel Hollow and Centereach. The scatter may be due to such factors as seasonal effects, storm duration and intensity, number of antecedent dry days, and basin slope. The small number of data points also contributes to the poor correlation.

According to the graphs in figure 8, the following amounts of runof $f$ are derived from 1 inch of precipitation:

$\begin{array}{lrlr}\text { Centereach } & 1.7 \text { inches } & \text { Plainview } & 0.82 \text { inches } \\ \text { Huntington } & .13 \text { inches } & \text { Syosset } & .60 \text { inches } \\ \text { Laurel Hollow } & .28 \text { inches } & & \end{array}$

These data correlate reasonably well with the median values given in table 8 , for reasons outlined above, and show that, in most instances, for 1 inch of precipitation, all runoff can be accounted for by the precipitation that falls directly on impervious surfaces. However, overland runoff from pervious surfaces may occur during storms of high intensity or long duration. 
Table 9.--Precipitation, munoff, and modified runoff/

[Locations are shown in fig. 2; dashes

\begin{tabular}{|c|c|c|c|c|c|c|c|c|c|}
\hline \multirow[b]{3}{*}{ Date } & \multirow{3}{*}{$\begin{array}{l}\text { Precipi- } \\
\text { tation } \\
\text { (1n) }\end{array}$} & \multicolumn{3}{|c|}{ Centereach } & \multirow{3}{*}{$\begin{array}{c}\text { Precipi- } \\
\text { tation } \\
\text { (in) }\end{array}$} & \multicolumn{2}{|c|}{ Huntington } & \multirow{3}{*}{$\begin{array}{l}\text { Runoff/ } \\
\text { Precipi- } \\
\text { tation } \\
\text { (per- } \\
\text { cent) }{ }^{a} \\
\end{array}$} & \multirow{3}{*}{$\begin{array}{l}\text { Laurel } \\
\text { Precipi- } \\
\text { tation } \\
\text { (1n) }\end{array}$} \\
\hline & & \multicolumn{2}{|c|}{ Runof $\mathrm{f}$} & \multirow{2}{*}{$\begin{array}{l}\text { Runoff/ } \\
\text { Precipi- } \\
\text { tation } \\
\text { (per- } \\
\text { cent) } \\
\end{array}$} & & \multicolumn{2}{|c|}{ Runof $\mathrm{f}^{\mathrm{a}}$} & & \\
\hline & & $\left(\mathrm{ft}^{3}\right)$ & (in) & & & $\left(\mathrm{ft}^{3}\right)$ & (in) & & \\
\hline $9-18-80$ & -- & -- & -- & -- & 0.59 & 3,330 & 0.03 & 4 & -- \\
\hline $10-25-80$ & - & -- & - & -- & 1.36 & $--b$ & $--b$ & $--b$ & -- \\
\hline $11-18-80$ & -- & - & -- & -- & -- & -- & -- & -- & 0.93 \\
\hline $11-24-80$ & -- & -- & -- & -- & -- & -- & -- & -- & 1.48 \\
\hline $12-9-80$ & -- & -- & -- & -- & -- & -- & -- & -- & -- \\
\hline $12-30-80$ & -- & -- & -- & -- & -- & -- & -- & -- & .20 \\
\hline $2-1-81$ & -- & -- & -- & -- & -- & -- & -- & -- & .85 \\
\hline $2-11-81$ & - & -- & -- & -- & -- & -- & -- & -- & -- \\
\hline $2-19-81$ & -- & -- & -- & -- & 1.49 & 17,200 & .14 & 9 & 1.80 \\
\hline $2-23-81$ & -- & -- & -- & -- & .75 & 6,860 & .05 & 7 & .82 \\
\hline $3-30-81$ & -- & -- & -- & -- & a .49 & 9,230 & .07 & 14 & .40 \\
\hline $4-14-81$ & - & - & -- & -- & $a_{1.03}$ & 4,610 & .03 & 3 & -- \\
\hline $4-23-81$ & -- & - & -- & -- & a . .73 & 650 & .005 & .7 & -- \\
\hline $5-11-81$ & -- & -- & -- & -- & a. .27 & 10,500 & .08 & 30 & .26 \\
\hline $5-29-81$ & -- & -- & -- & -- & .86 & 21,900 & .17 & 20 & -- \\
\hline $7-3-81$ & - & -- & -- & -- & -- & -- & -- & -- & .88 \\
\hline $7-20-81$ & -- & -- & -- & -- & .95 & 15,400 & .12 & 13 & -- \\
\hline $7-29-81$ & -- & -- & - & -- & -- & - & -- & -- & -- \\
\hline $9-8-81$ & -- & -- & -- & -- & -- & -- & -- & -- & -- \\
\hline $9-15-81$ & -- & -- & -- & -- & 1.65 & 112,000 & .88 & 53 & -- \\
\hline $12-1-81$ & - & - & -- & -- & -- & -- & -- & -- & -- \\
\hline $12-15-81$ & -- & -- & -- & -- & -- & -- & -- & -- & -- \\
\hline $1-23-82$ & - & - & - & -- & 1.33 & 56,900 & .45 & 34 & -- \\
\hline $2-2-82$ & -- & -- & -- & -- & -- & -- & -- & - & -- \\
\hline $3-4-82$ & 0.84 & 27,500 & 1.3 & 166 & -- & -- & -- & -- & -- \\
\hline $3-16-82$ & .65 & 7,750 & .37 & 57 & -- & -- & -- & -- & -- \\
\hline $4-26-82$ & $a_{1.89}$ & $a_{31,800}$ & 1.5 & 79 & -- & -- & -- & -- & -- \\
\hline $6-1-82$ & 1.55 & 57,700 & 2.7 & 174 & -- & -- & -- & -- & -- \\
\hline $6-5-82$ & 4.84 & 191,000 & 9.0 & 186 & -- & -- & -- & -- & -- \\
\hline $6-16-82$ & .45 & 19,100 & .91 & 202 & -- & -- & -- & -- & -- \\
\hline
\end{tabular}

a estimated

b equipment failure 
precipitation ratio for sampled storms, 1980-82.

indicate that no samples were collected]

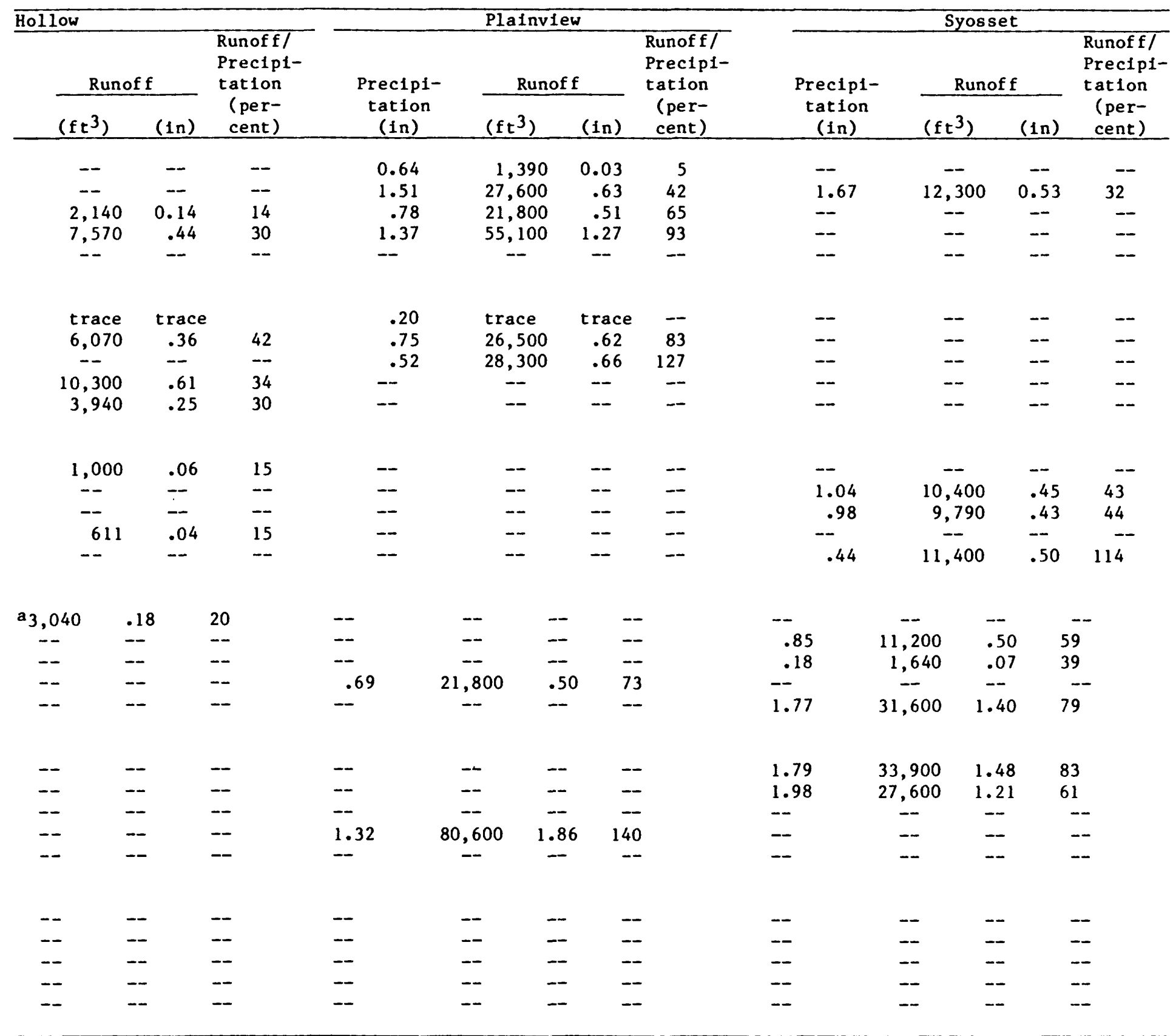



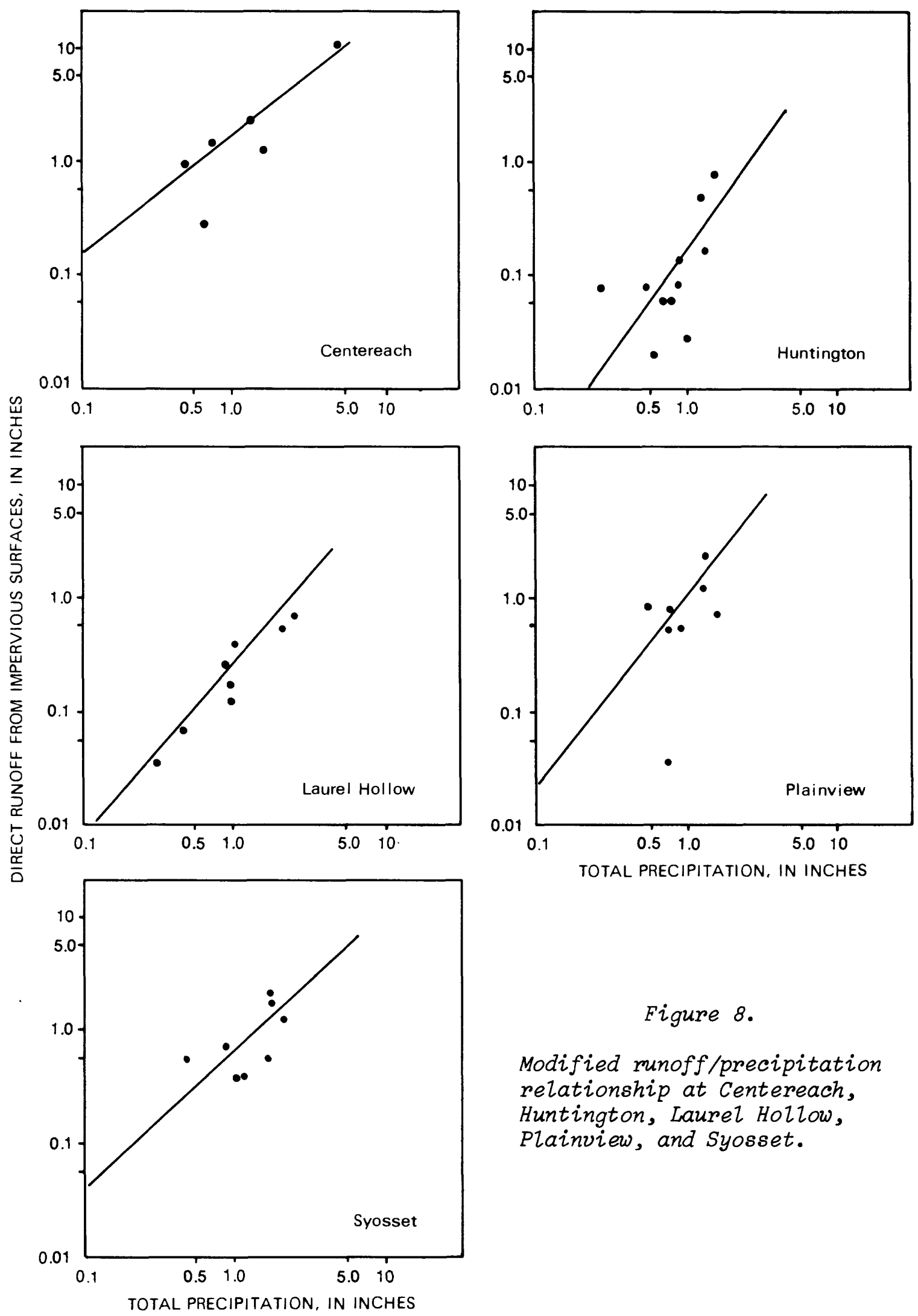

Figure 8.

Modified munf/precipitation relationship at Centereach, Huntington, Laurel Hollow, Plainview, and Syosset. 


\section{RELATIONSHIP OF STORMWATER QUALITY TO GROUND-WATER QUALITY}

\section{Concentration of Selected Constituents}

Median values of selected physical and chemical characteristics of stormwater, ground water, and precipitation for all storms sampled during 1980-82 at each of the five basins are given in table 10.

\section{Standard Chemicals}

The data in table 10 indicate that, in general, concentrations of most chemical constituents referred to herein as "standard chemicals" were relatively low and were within the standards for potable water. (Standard chemicals are listed in appendix A; State and Federal drinking-water standards

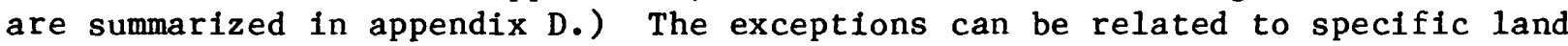
uses and seasonal effects. For example, the plainview basin, which receives stormwater runoff from a major highway, had a median lead concentration of 275 $\mu \mathrm{g} / \mathrm{L}$ and a maximum concentration of $3,300 \mu \mathrm{g} / \mathrm{L}$. Chloride concentrations at all basins were generally higher during winter, with a maximum of $1,100 \mathrm{mg} / \mathrm{L}$ at Huntington, as a result of the use of salt for road deicing.

Typical hydrographs (discharge as a function of time), hyetographs (rainfall as a function of time), and plots of constituent concentrations as a function of time for each site are shown in figures $9 \mathrm{~A}$ through $9 \mathrm{E}$ (p. 41-45). These graphs indicate a nearly immediate runoff response in storm-sewered areas. The constituent plots show that peak concentrations of lead, chromium, chloride, and total nitrogen coincide with the first runoff peak but not generally with later runoff peaks. This is probably due to the nearly complete removal of pollutants from the streets with the first major surge of water. During a storm of long duration (16 hours) that was sampled at Centereach on June 5, 1982, the chemical quality of the stormwater runoff gradually approached that of the precipitation. Therefore, no attempt was made here to correlate discharge with constituent concentrations because no physical relationship exists between the two.

To investigate the degree of accumulation of standard constituents in snow cover, limited snow sampling was conducted on January 10, 1981 at Huntington, Laurel Hollow, Plainview, and Syosset. The snow was taken from the recharge basin shoulder within $10 \mathrm{ft}$ of the edge.

The samples represent the precipitation accumulated from January 2 through January 10, 1981. Although 6 inches of snow fell on eastern Long Island during this time (table $11, \mathrm{p} .46$ ), the snow was only about 4 inches deep at the time the samples were collected. Between January 2 and January 10 , maximum daily temperatures ranged from $27^{\circ} \mathrm{F}$ to $35^{\circ} \mathrm{F}$, and mi nimum daily temperature ranged from $0^{\circ} \mathrm{F}$ to $12^{\circ} \mathrm{F}$. Therefore, it can be assumed that little or no snowmelt or runoff took place.

The concentrations of most inorganic constituents in snow samples were low (less than $10 \mathrm{mg} / \mathrm{L}$ ) and were similar to those found in rainfall. A comparison of median concentrations of chromium and lead in snow and in rainfall (table 12, p. 46) indicates no major difference in chromium concentrations, but the lead concentrations were slightly higher in snow at three of the four sites, which may be due to atmospheric fallout over the 8-day period. 
Table 10.--Median values of physical and chemical characteristics of stormwater, ground water, and precipitation.

[Data collected 1980-82; locations are shown In f1g. 2.]

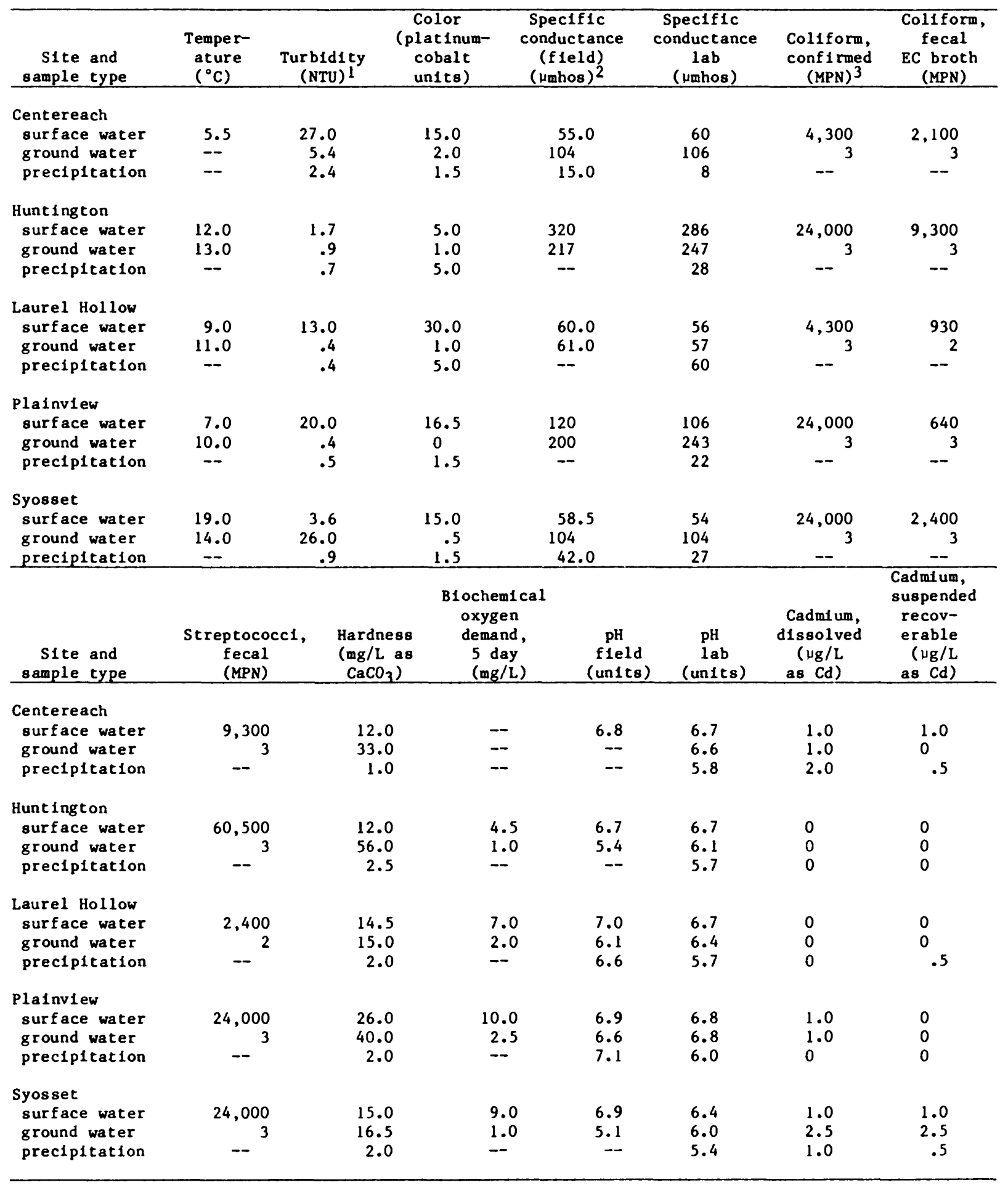

Nephelometric Turbidity Unit

micrombos per centimeter at $25^{\circ} \mathrm{C}$

MPN, most probable number

-- data unava1lable 
Table 10.--Median values of physical and chemical characteristics of stormwater, ground water, and precipitation (continued)

[Data collected 1980-82; locations are shown in fig. 2.]

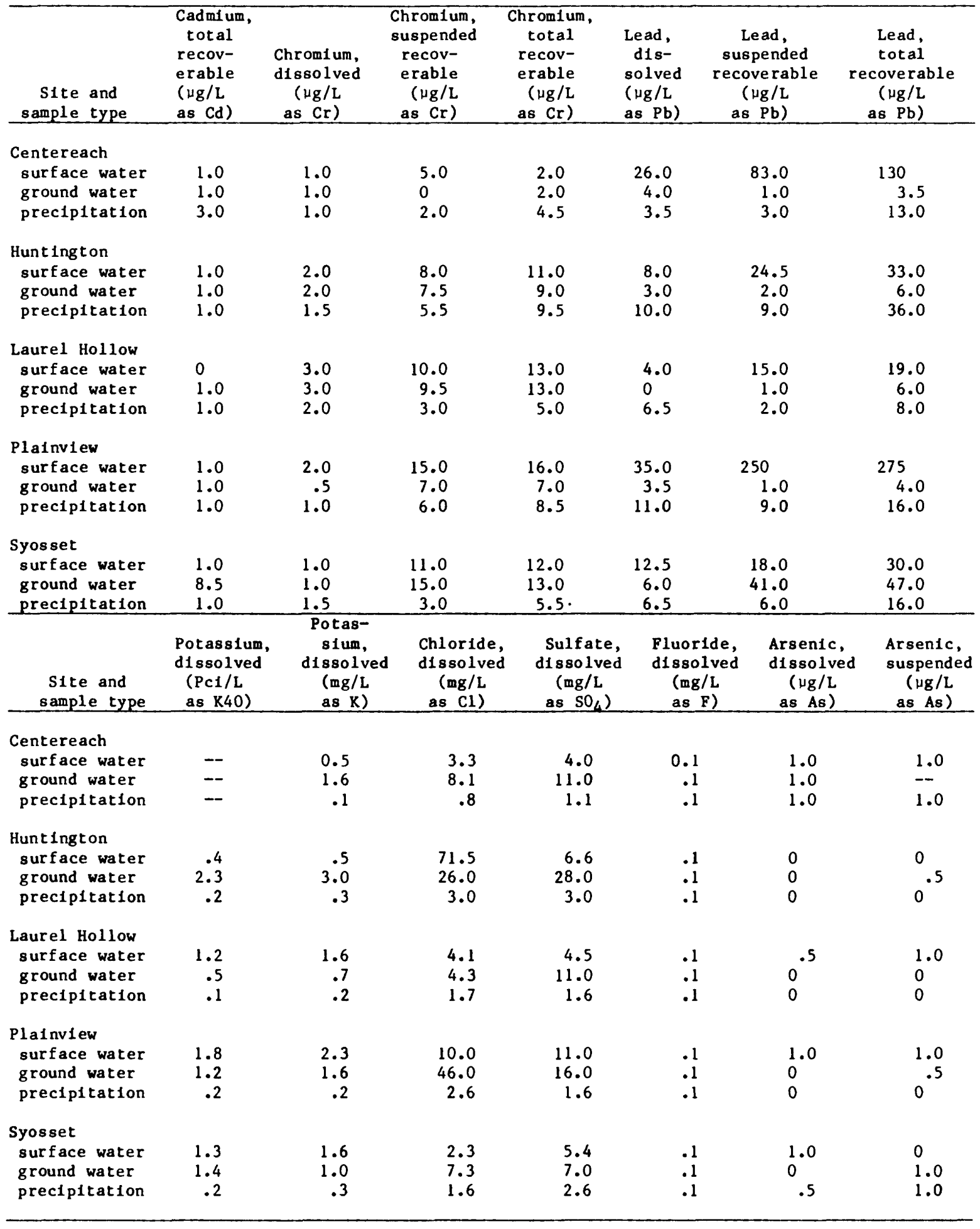

-- data unavallable 
Table 10.--Median values of physical and chemical characteristics of stormwater, ground water, and precipitation (continued)

[Data collected 1980-82; locations are shown in fig. 2.]

\begin{tabular}{|c|c|c|c|c|c|c|c|c|}
\hline $\begin{array}{c}\text { Site and } \\
\text { sample type } \\
\end{array}$ & $\begin{array}{c}\text { Arsentc, } \\
\text { total } \\
(\mu \mathrm{g} / \mathrm{L} \\
\text { as As }) \\
\end{array}$ & $\begin{array}{l}\text { Phos- } \\
\text { phorus, } \\
\text { ortho, } \\
\text { d1s8olved } \\
\text { (mg/L } \\
\text { as P) } \\
\end{array}$ & $\begin{array}{l}\text { Carbon, } \\
\text { organic } \\
\text { dissolved } \\
(\mathrm{mg} / \mathrm{L} \\
\mathrm{as} \mathrm{C}) \\
\end{array}$ & $\begin{array}{c}\text { Carbon, } \\
\text { organic } \\
\text { suspended } \\
\text { (mg/L } \\
\text { as C) } \\
\end{array}$ & $\begin{array}{c}\text { Cyanide, } \\
\text { total } \\
(\mathrm{mg} / \mathrm{L} \\
\text { as CN) } \\
\end{array}$ & $\begin{array}{l}\text { Calcium, } \\
\text { dissolved } \\
(\mathrm{mg} / \mathrm{L} \\
\text { as } \mathrm{Ca}) \\
\end{array}$ & $\begin{array}{c}\text { Magnesium, } \\
\text { d1ssolved } \\
(\mathrm{mg} / \mathrm{L} \\
\text { as } \mathrm{Mg}) \\
\end{array}$ & \\
\hline $\begin{array}{l}\text { Centereach } \\
\text { surface water } \\
\text { ground water } \\
\text { precipitation }\end{array}$ & $\begin{array}{l}1.0 \\
1.0 \\
1.0\end{array}$ & $\begin{array}{r}0.02 \\
.01 \\
.02\end{array}$ & $\begin{array}{l}6.4 \\
2.5 \\
2.7\end{array}$ & $\begin{array}{r}5.6 \\
.6 \\
.7\end{array}$ & $\begin{array}{l}-- \\
--\end{array}$ & $\begin{array}{l}3.5 \\
7.5 \\
.20\end{array}$ & $\begin{array}{l}0.69 \\
1.4 \\
.10\end{array}$ & \\
\hline $\begin{array}{l}\text { Huntington } \\
\text { surface water } \\
\text { ground water } \\
\text { precipitation }\end{array}$ & $\begin{array}{l}0 \\
0 \\
.5\end{array}$ & $\begin{array}{l}.03 \\
.01 \\
.02\end{array}$ & $\begin{array}{l}3.4 \\
1.3 \\
3.5\end{array}$ & $\begin{array}{r}4.0 \\
.9 \\
2.0\end{array}$ & $\begin{array}{l}.011 \\
\text { ND } \\
--\end{array}$ & $\begin{array}{c}3.7 \\
17.0 \\
.49\end{array}$ & $\begin{array}{c}.7 \\
3.5 \\
.26\end{array}$ & \\
\hline $\begin{array}{l}\text { Laurel Hollow } \\
\text { surface water } \\
\text { ground water } \\
\text { prectpitation }\end{array}$ & $\begin{array}{l}1.0 \\
0 \\
0\end{array}$ & $\begin{array}{l}.06 \\
.01 \\
.01\end{array}$ & $\begin{array}{l}5.8 \\
1.8 \\
1.0\end{array}$ & $\begin{array}{r}6.9 \\
1.6 \\
.7\end{array}$ & $\begin{array}{l}.02 \\
\text { ND } \\
--\end{array}$ & $\begin{array}{c}4.3 \\
4.5 \\
.30\end{array}$ & $\begin{array}{l}.8 \\
.9 \\
.10\end{array}$ & \\
\hline $\begin{array}{l}\text { Plainview } \\
\text { surface water } \\
\text { ground water } \\
\text { precipltation }\end{array}$ & $\begin{array}{l}1.5 \\
1.0 \\
1.0\end{array}$ & $\begin{array}{l}.05 \\
.01 \\
.02\end{array}$ & $\begin{array}{l}6.9 \\
2.4 \\
1.8\end{array}$ & $\begin{array}{r}7.3 \\
.9 \\
1.6\end{array}$ & $\begin{array}{l}\text { ND } \\
\text { ND } \\
--\end{array}$ & $\begin{array}{l}7.85 \\
9.0 \\
.4\end{array}$ & $\begin{array}{r}1.2 \\
3.6 \\
.2\end{array}$ & \\
\hline $\begin{array}{l}\text { Syosset } \\
\text { surface water } \\
\text { ground water } \\
\text { precipitation }\end{array}$ & $\begin{array}{l}1.0 \\
1.0 \\
1.0\end{array}$ & $\begin{array}{l}.09 \\
.01 \\
.03 \\
\end{array}$ & $\begin{array}{l}6.3 \\
1.1 \\
2.6 \\
\end{array}$ & $\begin{array}{l}5.1 \\
1.3 \\
1.6 \\
\end{array}$ & $\begin{array}{l}\text { ND } \\
\text { ND } \\
- \\
\end{array}$ & $\begin{array}{l}3.7 \\
4.85 \\
.50 \\
\end{array}$ & $\begin{array}{l}1.25 \\
1.2 \\
.18 \\
\end{array}$ & \\
\hline $\begin{array}{r}\text { Site and } \\
\text { sample type } \\
\end{array}$ & $\begin{array}{l}\text { Sodium, } \\
\text { dissolved } \\
\text { (mg/L } \\
\text { as } \mathrm{Na}) \\
\end{array}$ & $\begin{array}{c}\text { N1 trogen, } \\
\text { dissolved } \\
(\mathrm{mg} / \mathrm{L} \\
\text { as } \mathrm{N})\end{array}$ & $\begin{array}{c}\text { N1trogen, } \\
\text { organlc } \\
\text { d1ssolved } \\
(\mathrm{mg} / \mathrm{L} \\
\text { as } \mathrm{N}) \\
\end{array}$ & $\begin{array}{c}\text { N1trogen, } \\
\text { ammonia } \\
\text { dissolved } \\
(\mathrm{mg} / \mathrm{L} \\
\text { as } \mathrm{N})\end{array}$ & $\begin{array}{c}\text { Nitrogen, } \\
\text { ammonia + } \\
\text { organic } \\
\text { dissolved } \\
\text { (mg/L } \\
\text { as } \mathrm{N}) \\
\end{array}$ & $\begin{array}{c}\text { Nitrogen, } \\
\mathrm{NH}_{4}+ \\
\text { organic } \\
\text { suspended } \\
(\mathrm{mg} / \mathrm{L} \\
\text { as } \mathrm{N}) \\
\end{array}$ & $\begin{array}{c}\text { Nitrogen, } \\
\text { ammonia + } \\
\text { organic } \\
\text { total } \\
(\mathrm{mg} / \mathrm{L} \\
\text { as } \mathrm{N}) \\
\end{array}$ & $\begin{array}{c}\mathrm{Nitrogen}, \\
\mathrm{NO}_{2}+\mathrm{NO}_{3} \\
\text { dissolved } \\
\text { (mg/L } \\
\text { as } \mathrm{N}) \\
\end{array}$ \\
\hline $\begin{array}{l}\text { Centereach } \\
\text { surface water } \\
\text { ground water } \\
\text { precipitation }\end{array}$ & $\begin{array}{r}3.5 \\
9.5 \\
.3\end{array}$ & $\begin{array}{l}1.9 \\
.91 \\
1.2\end{array}$ & $\begin{array}{r}0.86 \\
.43 \\
.46\end{array}$ & $\begin{array}{l}0.08 \\
.05 \\
.08\end{array}$ & $\begin{array}{l}0.96 \\
.5 \\
.78\end{array}$ & $\begin{array}{c}0.20 \\
-- \\
.15\end{array}$ & $\begin{array}{l}1.15 \\
.10 \\
.60\end{array}$ & $\begin{array}{r}0.42 \\
.31 \\
.10\end{array}$ \\
\hline $\begin{array}{l}\text { Huntington } \\
\text { surface water } \\
\text { ground water } \\
\text { precipitation }\end{array}$ & $\begin{array}{r}40.0 \\
19.0 \\
1.8\end{array}$ & $\begin{array}{c}.9 \\
6.3 \\
.80\end{array}$ & $\begin{array}{l}.33 \\
.20 \\
.26\end{array}$ & $\begin{array}{l}.15 \\
.02 \\
.13\end{array}$ & $\begin{array}{l}.49 \\
.28 \\
.58\end{array}$ & $\begin{array}{l}.17 \\
.02 \\
.01\end{array}$ & $\begin{array}{l}.65 \\
.32 \\
.67\end{array}$ & $\begin{array}{c}.34 \\
5.8 \\
.26\end{array}$ \\
\hline $\begin{array}{l}\text { Laurel Hollow } \\
\text { surface water } \\
\text { ground water } \\
\text { precipitation }\end{array}$ & $\begin{array}{l}3.3 \\
3.7 \\
1.1\end{array}$ & $\begin{array}{l}1.0 \\
1.0 \\
.29\end{array}$ & $\begin{array}{l}.44 \\
.17 \\
.13\end{array}$ & $\begin{array}{l}.08 \\
.02 \\
.04\end{array}$ & $\begin{array}{l}.55 \\
.19 \\
.16\end{array}$ & $\begin{array}{l}.70 \\
.23 \\
.01\end{array}$ & $\begin{array}{l}1.5 \\
.41 \\
.20\end{array}$ & $\begin{array}{l}.44 \\
.82 \\
.16\end{array}$ \\
\hline $\begin{array}{l}\text { Plalnview } \\
\text { surface water } \\
\text { ground water } \\
\text { precipltation }\end{array}$ & $\begin{array}{r}8.5 \\
27.0 \\
.5\end{array}$ & $\begin{array}{l}1.3 \\
1.3 \\
.59\end{array}$ & $\begin{array}{l}.58 \\
.20 \\
.10\end{array}$ & $\begin{array}{l}.12 \\
.02 \\
.08\end{array}$ & $\begin{array}{l}.7 \\
.24 \\
.16\end{array}$ & $\begin{array}{l}1.35 \\
0 \\
0\end{array}$ & $\begin{array}{l}2.3 \\
.15 \\
.32\end{array}$ & $\begin{array}{l}.49 \\
.82 \\
.28\end{array}$ \\
\hline $\begin{array}{l}\text { Syosset } \\
\text { surface water } \\
\text { ground water } \\
\text { preclpitation }\end{array}$ & $\begin{array}{l}1.5 \\
4.2 \\
1.0\end{array}$ & $\begin{array}{l}1.35 \\
2.55 \\
1.20\end{array}$ & $\begin{array}{l}.60 \\
.38 \\
.29\end{array}$ & $\begin{array}{l}.09 \\
.02 \\
.16\end{array}$ & $\begin{array}{l}.76 \\
.39 \\
.66\end{array}$ & $\begin{array}{l}.6 \\
.04 \\
.02\end{array}$ & $\begin{array}{r}1.35 \\
.40 \\
.64\end{array}$ & $\begin{array}{r}.34 \\
1.60 \\
.42\end{array}$ \\
\hline
\end{tabular}

-- data unavaflable ND, not detected 

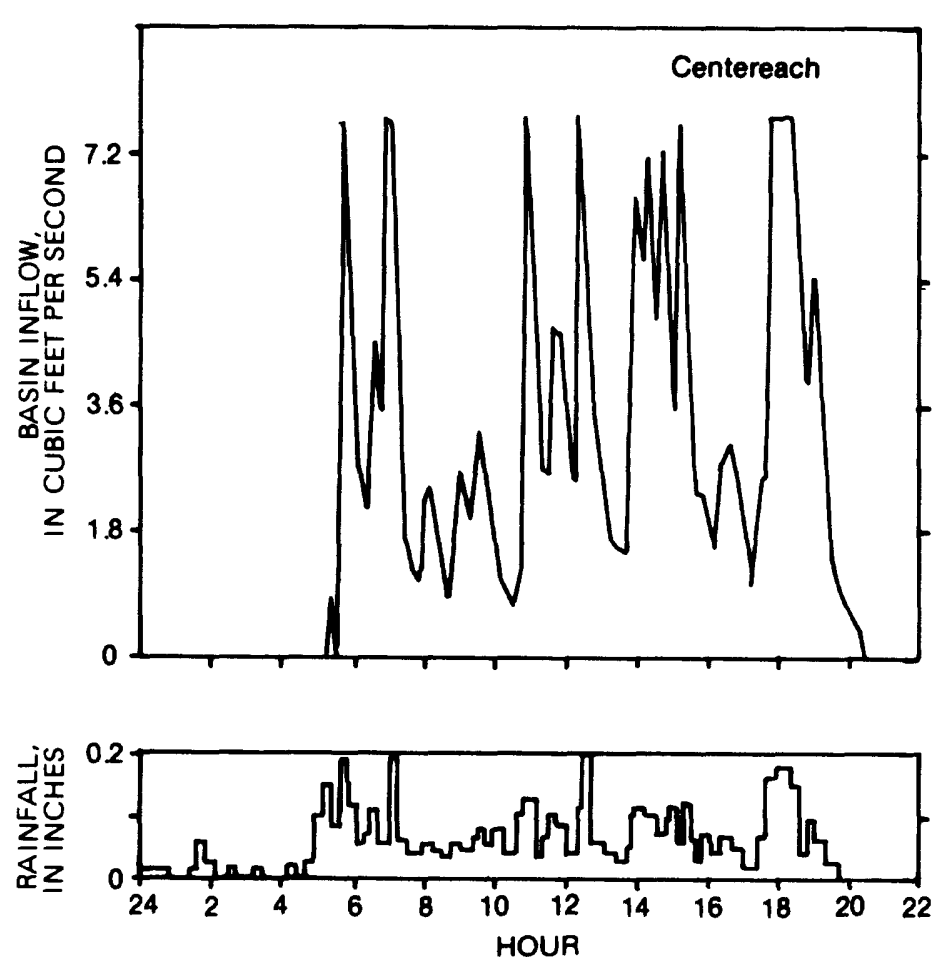

Figure $9 A$.

Hydrograph and hyetograph (above), and constituent concentrations through time (below) during storm of June 5, 1982, at Centereach.
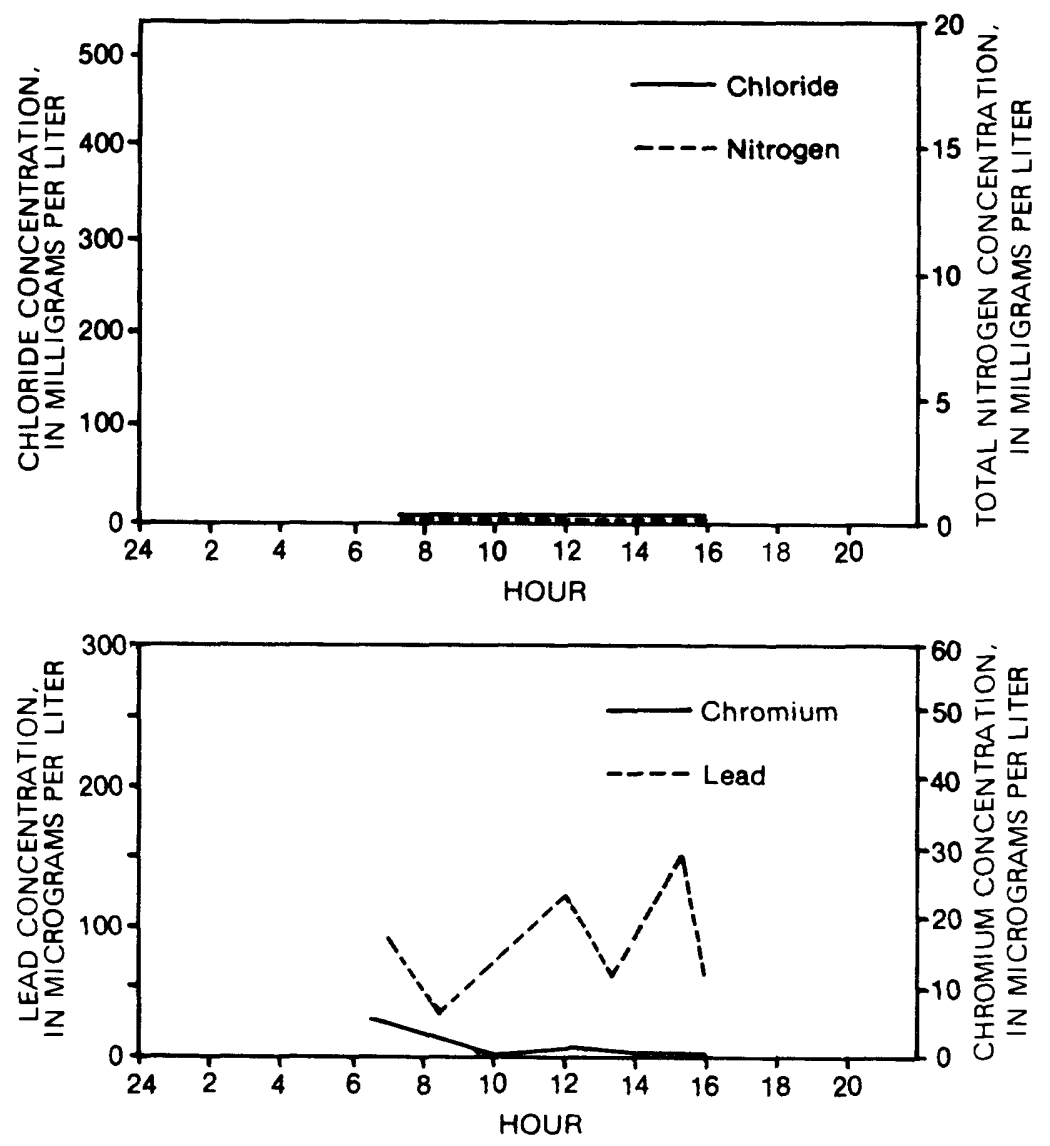

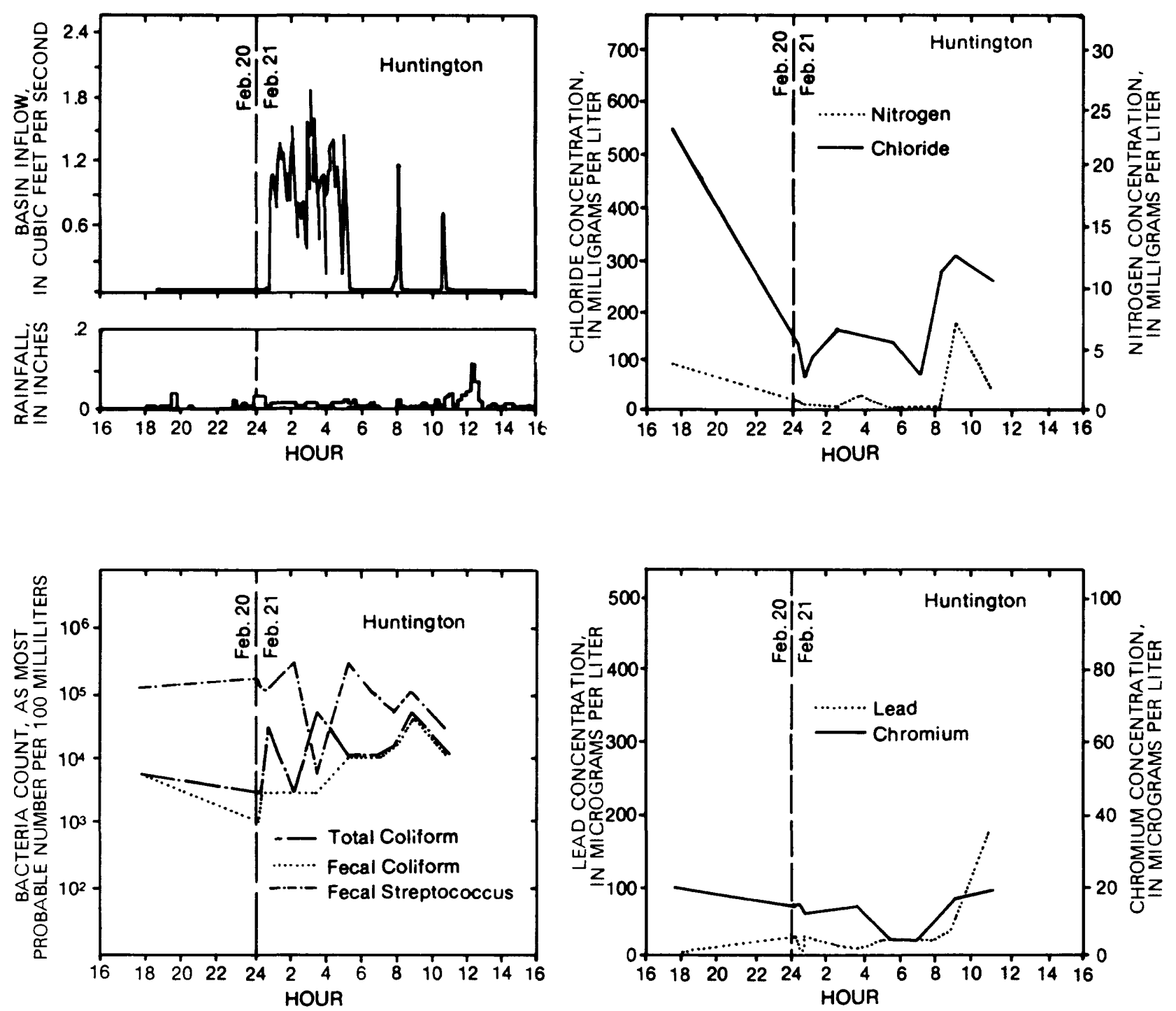

Figure 9B.--Hydrograph and hyetograph (upper left) and constituent concentrations through time during storm of

February 20, 1981 at Huntington. 

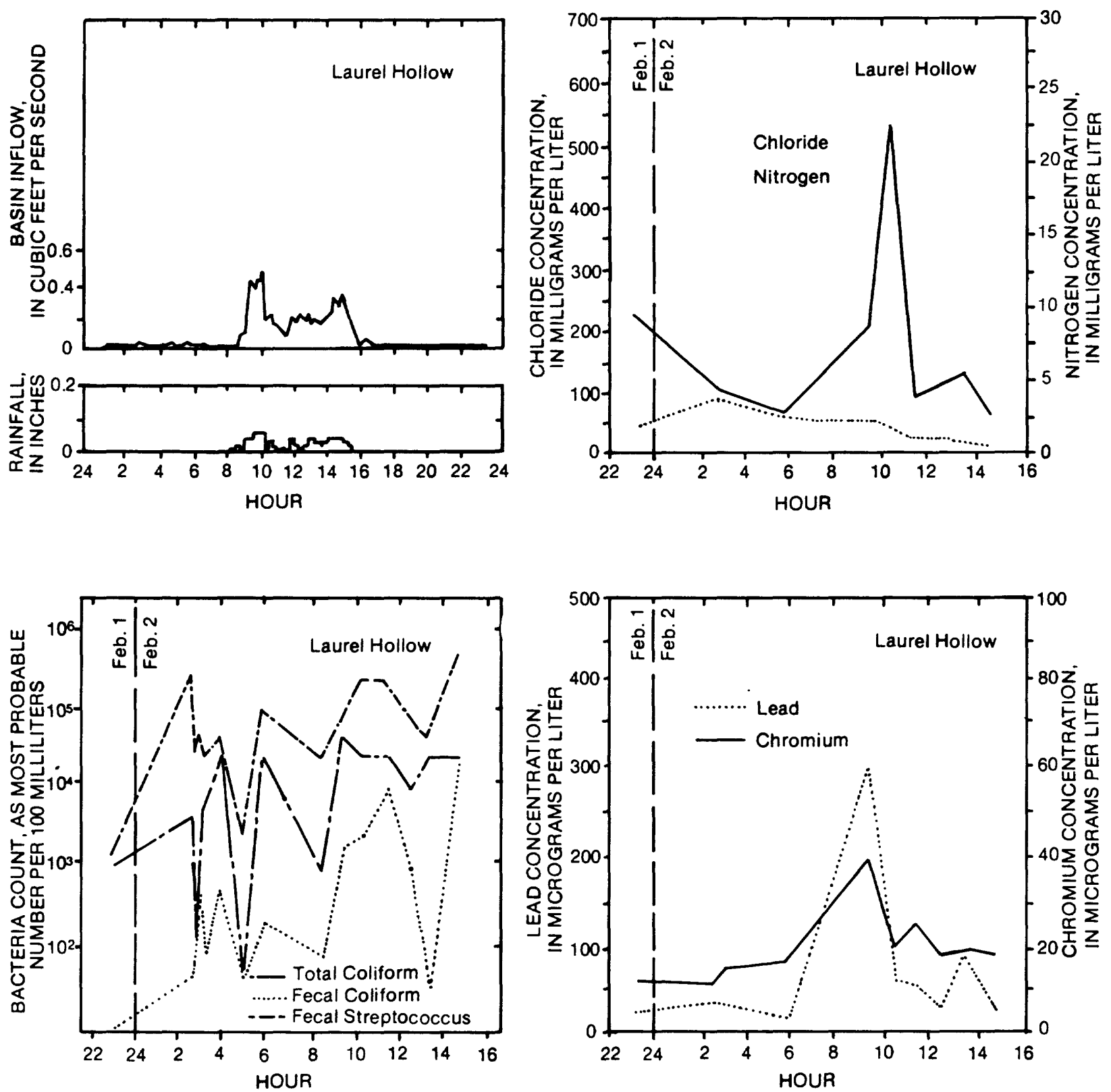

Figure $9 .-$-Hydrograph and hyetograph (upper left) and constituent concentrations through time during storm of February 1, 1981 at Laurel Hollow. 

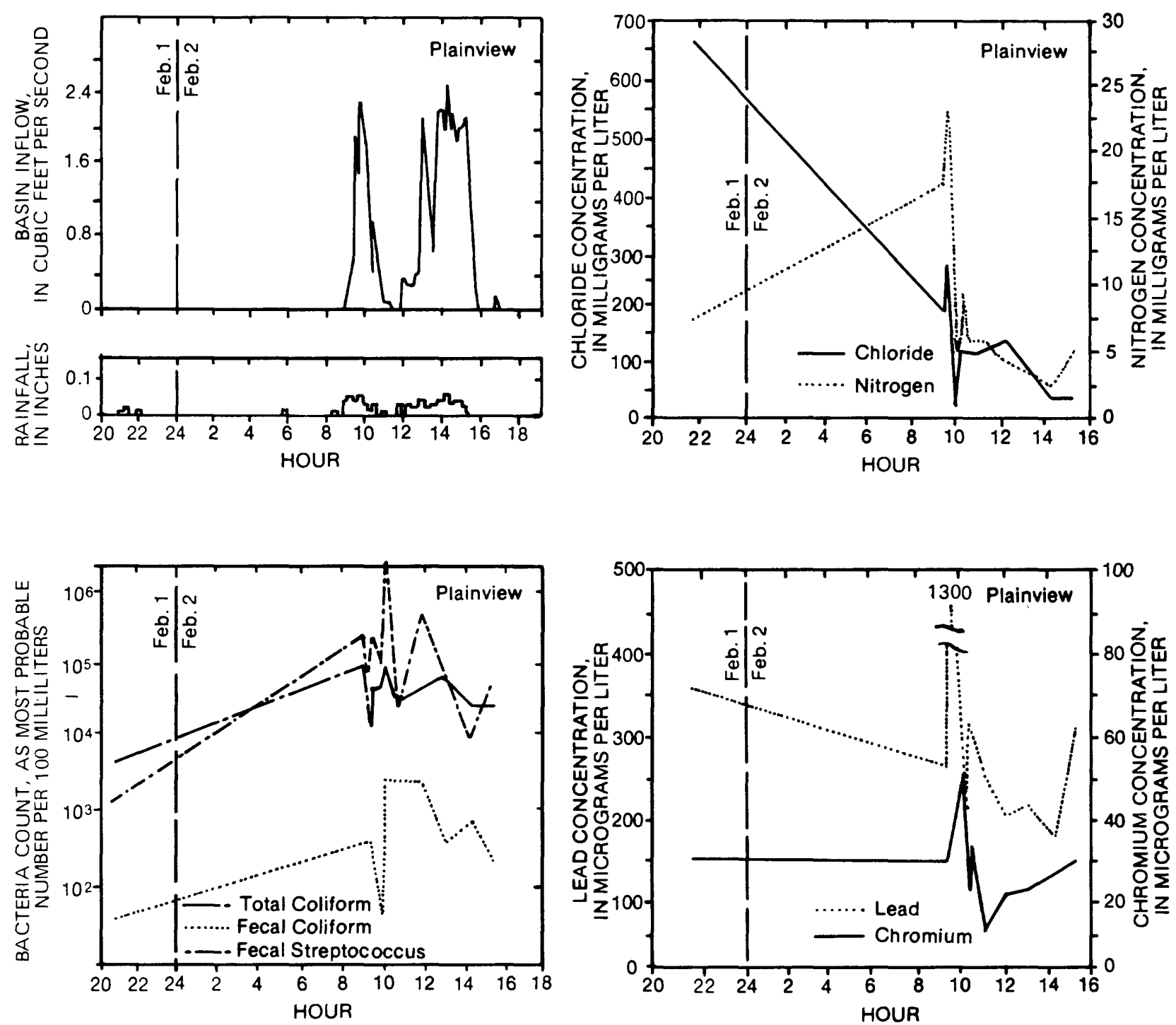

Figure 9D.--Hydrograph and hyetograph (upper left) and constituent concentrations through time during storm of February 1, 1981 at Plainview. 

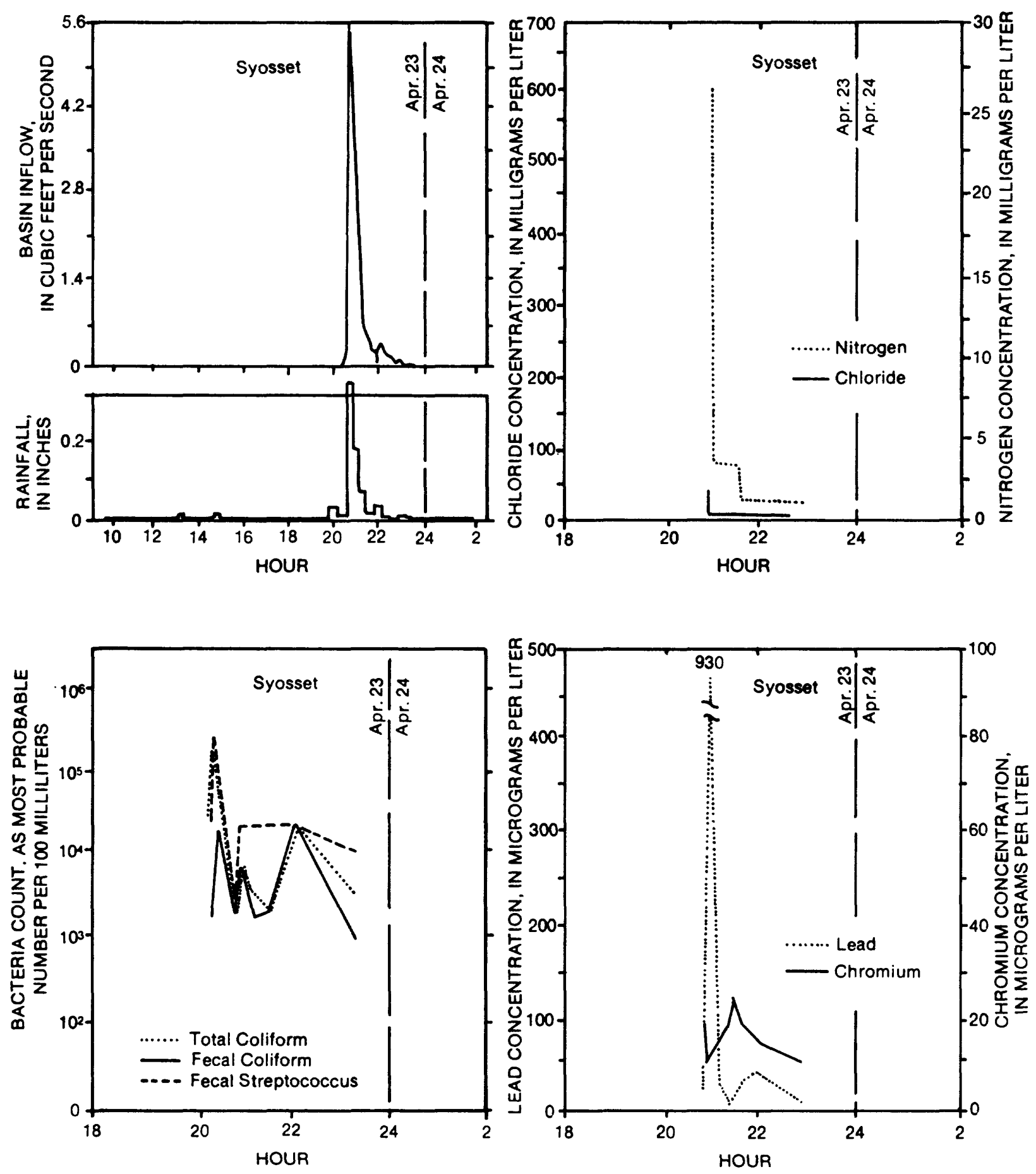

Figure 9E.--Hydrograph and hyetograph (upper left) and constituent concentrations through time during storm of April 23, 1981 at Syosset. 
Table 11.--Total daily snowfall, eastern Long Island, January 2-10, 1981.

\begin{tabular}{lllc}
\hline Date & $\begin{array}{c}\text { Total daily snowfall } \\
\text { (inches) }\end{array}$ & Date & $\begin{array}{c}\text { Total daily snowfall } \\
\text { (inches) }\end{array}$ \\
\hline $1-2-81$ & 1.50 & $1-7-81$ & 3.00 \\
$1-3-81$ & 0 & $1-8-81$ & 0 \\
$1-4-81$ & 1.53 & $1-9-81$ & 0 \\
$1-5-81$ & 0 & $1-10-81$ & 0 \\
$1-6-81$ & 0 & & \\
\hline
\end{tabular}

Table 12.-Comparison of median lead and chromium concentrations in rainfall (1980-82) and accumulated snow, January 10, 1981.

[A11 values are in $\mu g / L$ ]

\begin{tabular}{|c|c|c|c|c|c|c|c|c|c|c|}
\hline & \multicolumn{2}{|c|}{ Centereach } & \multicolumn{2}{|c|}{ Huntington } & \multicolumn{2}{|c|}{ Laurel Hollow } & \multicolumn{2}{|c|}{ Plainview } & \multicolumn{2}{|c|}{ Syosset } \\
\hline & Snow & $\begin{array}{l}\text { Median } \\
\text { precip. }\end{array}$ & Snow & $\begin{array}{l}\text { Median } \\
\text { precip. }\end{array}$ & & $\begin{array}{l}\text { Median } \\
\text { precip. }\end{array}$ & & $\begin{array}{l}\text { Median } \\
\text { precip. }\end{array}$ & Snow & $\begin{array}{l}\text { Median } \\
\text { precip. }\end{array}$ \\
\hline Lead & - & 13 & 24 & 36 & 28 & 8 & 33 & 16 & 18 & 16 \\
\hline Chromium & - & 4.5 & 8 & 9.5 & 4 & 5 & 10 & 8.5 & 6 & 5.5 \\
\hline
\end{tabular}

-- not sampled

\section{Priority Polzutants}

The results of the priority pollutant (organic chemical) analyses are summarized in table 13. Only compounds detected in the samples are included; most compounds were below detection limits. Table $13 \mathrm{~A}$ lists the concentrations of the acid- and base/neutral-extractable compounds in the stormwater and ground-water samples; table 13B lists the concentrations of the volatile compounds, phenols, and cyanide. Replicate samples were collected on each sampling day for quality assurance. These results are also included in the tables, as are analyses of room air (in the analyzing laboratory), trip blanks (distilled water carried during sampling) and deionized water blanks. These additional values are presented for comparison with regular sample analyses.

New York State Department of Health guidelines for organic chemicals in drinking water recommend no more than $50 \mathrm{\mu g} / \mathrm{L}$ for an individual constituent, $100 \mu \mathrm{g} / \mathrm{L}$ for total organic chemical constituents, and $5 \mu \mathrm{g} / \mathrm{L}$ for vinyl chloride and benzene, known carcinogens. (See appendix D.) of the 14 samples analyzed for 113 of the priority pollutants, three contained one or two substances in concentrations exceeding the guidelines for a single organic chemical constituent ( $t a b l e 14$ ). These samples also contained a combination of substances that exceeded the guidelines for total organic constituents.

The most common organic compounds (those found in at least 50 percent of the samples collected) were:

benzene

bis (2-ethylhexyl) phthalate chlorof orm methylene chloride

toluene

1,1,1-trichloroethane 
of these, only methylene chloride was consistently found in concentrations greater than $8 \mathrm{\mu g} / \mathrm{L}$.

\section{Bacteria}

Total coliforms, fecal coliforms, and fecal streptococci are known as "indicator" organisms because they are often considered to indicate the presence of sewage and, ideally, are correlated with the number of pathogens in a water sample. Although the use of coliforms as an indicator has been criticized, the U.S. Environmental Protection Agency's safe drinking-water standards are written in terms of coliforms rather than pathogens, as are standards for recreational waters and shellfishing areas (Mallard, 1980).

Most total coliform bacteria in runoff are native soil organisms that are washed off soil particles by water running over the land surface. Fecal coliforms and fecal streptococci, however, are contributed by warm-blooded animals. In urban areas, these bacteria are most likely derived from fecal material from dogs, cats, rodents, and other small animals. On Long Island, ducks and seagulls are also significant contributors of bacteria to surface water (Koppelman, 1982).

Counts (MPN) of total coliforms, fecal coliforms, and fecal streptococci in stormwater, compiled by Mallard (1980) from several references, range as follows :

$$
\begin{array}{lll}
\text { total coliforms } & 10^{3} \text { to } 10^{5} \text { per } 100 \mathrm{~mL} \text {; } \\
\text { fecal coliforms } & 10^{2} \text { to } 10^{4} \text { per } 100 \mathrm{~mL} \text {; } \\
\text { fecal streptococci } & 10^{2} \text { to } 10^{5} \text { per } 100 \mathrm{~mL} \text {. }
\end{array}
$$

The minimum, maximum, and median values of the three indicator bacteria at each of the five sites studied are listed in table 15. These bacteria counts, from 306 stormwater samples, were generally within the above-listed ranges, although values an order of magnitude above or below these range limits were common.

Geldreich and Kenner (1969) found that the ratio of fecal coliforms to fecal streptococci (FC:FS) in human feces and in water polluted with human waste is always greater than 4.0, whereas the FC:FS ratio in feces from farm animals, cats, dogs, and rodents, and in separate stormwater systems and farmland drainage, is less than 0.7 .

Although the FC:FS ratio gives some indication of the source of the bacteria, Mallard (1980) warns that factors such as temperature, pH, metal concentration, nutrient availability, and other environmental factors will alter the ratio once the organisms enter the receiving water. These effects can be minimized by collecting water samples as soon as possible, near the source of the contamination, before the bacteria reach the receiving-water body. Also, the FC:FS ratio for samples that contain water from a mixture of nonpoint sources must be interpreted with caution. For example, if most of the bacteria in a sample came from nonhuman sources, a small amount of human sewage might not cause a sufficient upward shift in the overall ratio to indicate the possible presence of human pathogens. 


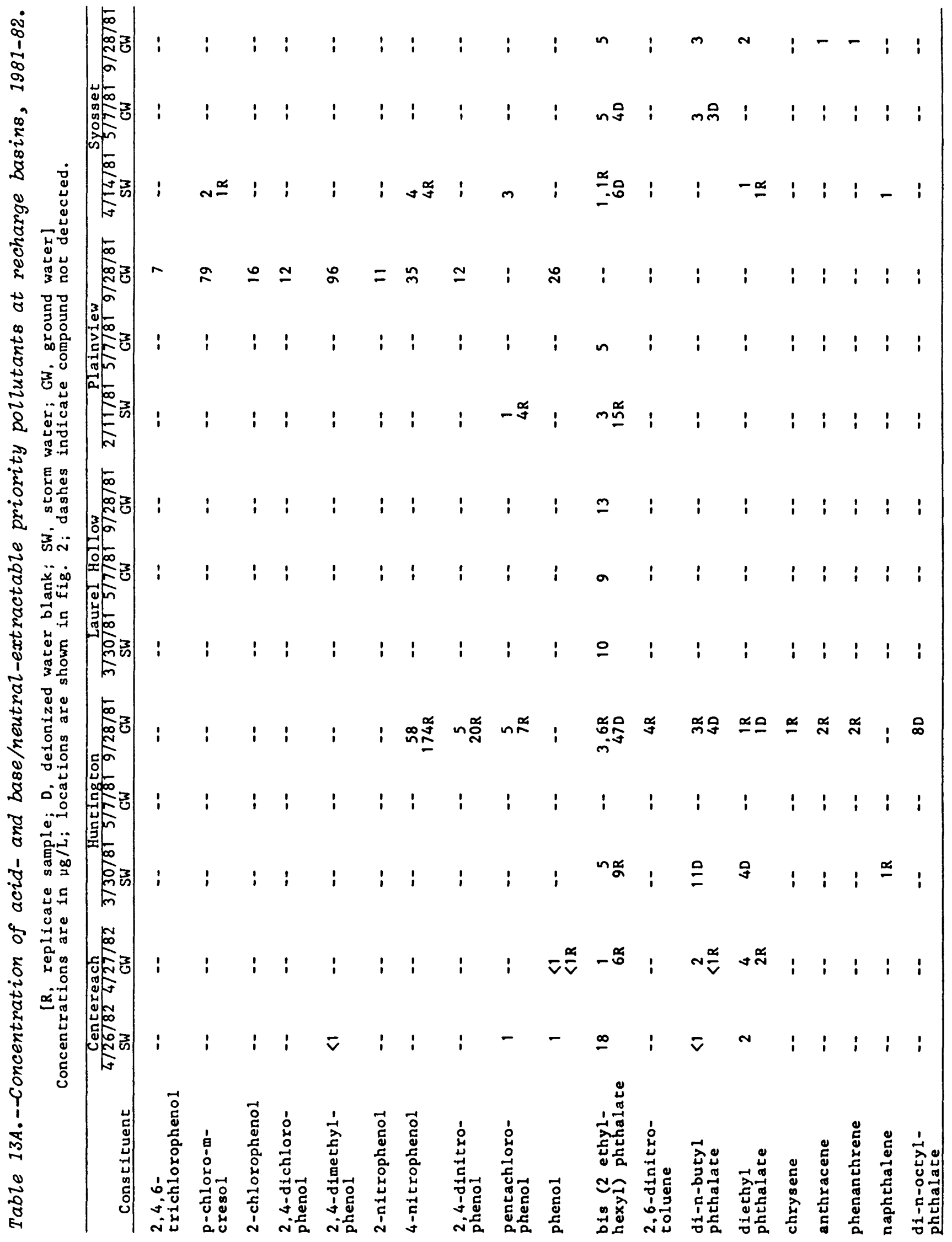




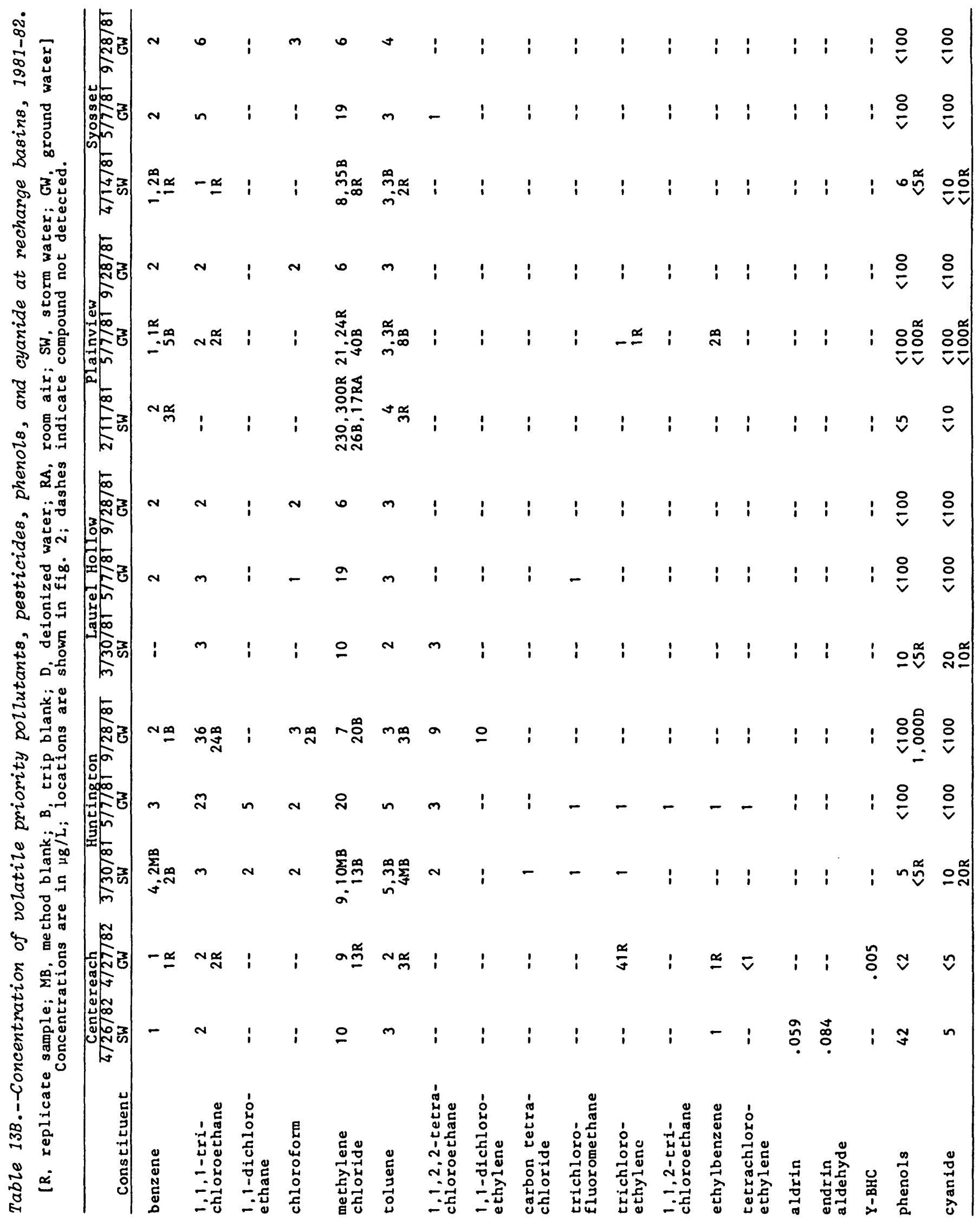


Table 14.--Priority pollutants exceeding New York State drinking-water standards at study sites.

(Locations are shown in fig. 2.)

\begin{tabular}{|c|c|c|c|c|}
\hline Basin & Date & Source & Constituent & $\begin{array}{c}\text { Concentration } \\
(\mu g / L)\end{array}$ \\
\hline $\begin{array}{l}\text { Plainview } \\
\text { Plainview } \\
\text { Huntington } \\
\text { Plainview }\end{array}$ & $\begin{array}{l}9-28-81 \\
9-28-81 \\
9-28-81 \\
2-11-81\end{array}$ & $\begin{array}{l}\text { ground water } \\
\text { ground water } \\
\text { ground water } \\
\text { storm water }\end{array}$ & $\begin{array}{l}\text { p-chloro-m-cresol } \\
2,4-\text { dimethylphenol } \\
\text { 4-nitrophenol } \\
\text { methylene chloride }\end{array}$ & $\begin{array}{r}79 \\
96 \\
58 \\
230\end{array}$ \\
\hline
\end{tabular}

Table 15.--Minimum, maximum, and median number of bacteria in stormwater for all samples.

[Values are MPN per 100 milliliters]

\begin{tabular}{lrrr}
\hline Bacteria & Minimum & Maximum & Median \\
\hline & Centereach & & \\
& & & \\
Total collforms & 240 & 43,000 & 4,300 \\
Fecal collforms & 4 & 43,000 & 930 \\
Fecal streptococcl & 640 & 46,000 & 24,000
\end{tabular}

Hunt Ingt on

Total collforms
Fecal collforms
Fecal streptococcl

Total coliforms

Fecal collforms

Fecal streptococcl

Total collforms

Fecal collforms

Fecal streptococc1

Total collforms

Fecal collforms

Fecal streptococcl

$$
\begin{array}{r}
2,400 \\
6 \\
2,400
\end{array}
$$

$1,100,000$ 240,000

24,000

$1,100,000$

126,650

Laurel Hollow

$\begin{array}{rrr}240 & 43,000 & 4,300 \\ 4 & 43,000 & 930 \\ 640 & 460,000 & 24,000\end{array}$

Pla1nview

$\begin{array}{rrr}240 & 1,100,000 & 24,000 \\ 43 & 43,000 & 640 \\ 150 & 2,400,000 & 24,000\end{array}$

Syosset

$\begin{array}{rrr}240 & 1,100,000 & 24,000 \\ 9 & 240,000 & 2,400 \\ 430 & 1,100,000 & 24,000\end{array}$


Table 16 shows the minimum, maximum, and median FC:FS ratios for stormwater runoff samples collected at each of the five sites, along with the number of samples from which these statistics were derived. In each case, the median ratio is well below 0.7 , which indicates that the probable source of the bacteria is animal waste. Two of the maximum values, 5.6 for Laurel Hollow and 16.0 for Huntington, are above 4.0. FC:FS ratios of this magnitude were extremely rare, however, and occurred in only 7 of the 279 samples (2.5 percent). Ratios exceeding 4.0 were found in only 1 of 58 samples from Laurel Hollow ( 1.7 percent) and in only 6 of 77 samples from Huntington (7.8 percent).

Soil is generally effective in removing bacteria from water, both by the filtering action of soil particles at land surface and by the adsorptive capacity of clay particles (Mallard, 1980). Thus, contamination of ground water by bacteria is unlikely.

Al1 five recharge basins were found to be effective in removing bacteria from stormwater before it reached the water table. Nearly all values of total coliforms, fecal coliforms, and fecal streptococci in ground water beneath the recharge basins, sampled 1 to 2 days after a storm, were less than $3.0 \mathrm{MPN} / 100 \mathrm{~mL}$.

Table 16.--Ratio of fecal coliform to fecal streptococci in stormuter ${ }^{1}$.

[Site locations are shown in $\mathrm{fig} .2$ ]

\begin{tabular}{lcccc}
\hline \multicolumn{1}{c}{ Site } & Minimum & Maximum & Median & $\begin{array}{c}\text { Number of } \\
\text { Samples }\end{array}$ \\
\hline Centereach & 0 & 1.8 & 0.10 & 27 \\
Huntington & 0 & 16.0 & .20 & 77 \\
Laurel Hollow & 0 & 5.6 & .05 & 58 \\
Plainview & 0 & 1.8 & .03 & 60 \\
$\begin{array}{l}\text { Syosset } \\
\text { TOTAL }\end{array}$ & 0 & 1.0 & .10 & $\frac{57}{279}$ \\
\hline
\end{tabular}

1 FC:FS $>4.0$ generally indicative of human waste as bacteria source; FC:FS $<0.7$ generally indicative of animal waste as bacteria source (Geldreich and Kenner, 1969).

\section{Loads of Selected Constltuents}

Stormwater constituent loads were calculated by multiplying the constituent concentration in each stormwater sample by the runoff volume in the associated storm segment, and then taking the sum of the individual storm-segment loads. Constituent loads were converted to flow-weighted concentrations by dividing by the total runoff volume (table 5) for the appropriate storm. Constituent loads in ground water were calculated by multiplying the observed constituent concentration in the infiltrated water by the total storm inflow volume. 


\section{Standard Chemicals}

Flow-weighted concentrations of selected constituents in stormwater inflow and observed concentrations in water that infiltrated through the recharge-basin floor to the water table are listed by basin and by storm in table 17A; constituent loads are shown in table 17B. The chemical constituents selected for this analysis were chromium and lead, which are associated with gasoline and industry, and chloride and nitrogen, which are associated with fertilizers and animal waste. Chloride is also derived from road salt used during winter.

Loads of chromium and lead in stormwater were generally low, ranging from virtually none $(0.001$ and $0.0031 \mathrm{~b}$, respective1y) to tenths of a pound. Where a large influx into the basin was noted, as at Plainview (table 17B), a large degree of removal also occurred. For example, the lead load in stormwater on February 11,1981 at Plainview was $2.031 \mathrm{~b}$, but when the same water reached the water table, it contained on $1 \mathrm{y} 0.01 \mathrm{lb}$, a decrease of 2 orders of magnitude. (A difference of less than an order of magnitude may be within the range of analytical precision.) The same is true of chromium, although the largest influx of chromium into a basin was only $0.1521 \mathrm{~b}$ (June 16, 1982 at (entereach).

A comparison of chloride and nitrogen loads in stormwater with those in ground water shows little or no removal of these constituents within the unsaturated zone. In fact, the loads in the ground water after some storms were greater than those in the stormwater (table 17B), presumably because they enter the ground water from other sources such as septic-tank and cesspool effluent and fertilizers ( $\mathrm{Ku}$ and Sulam, 1979). Figure 10 uses the Plainview site as an example to show that nitrogen concentrations in ground water were

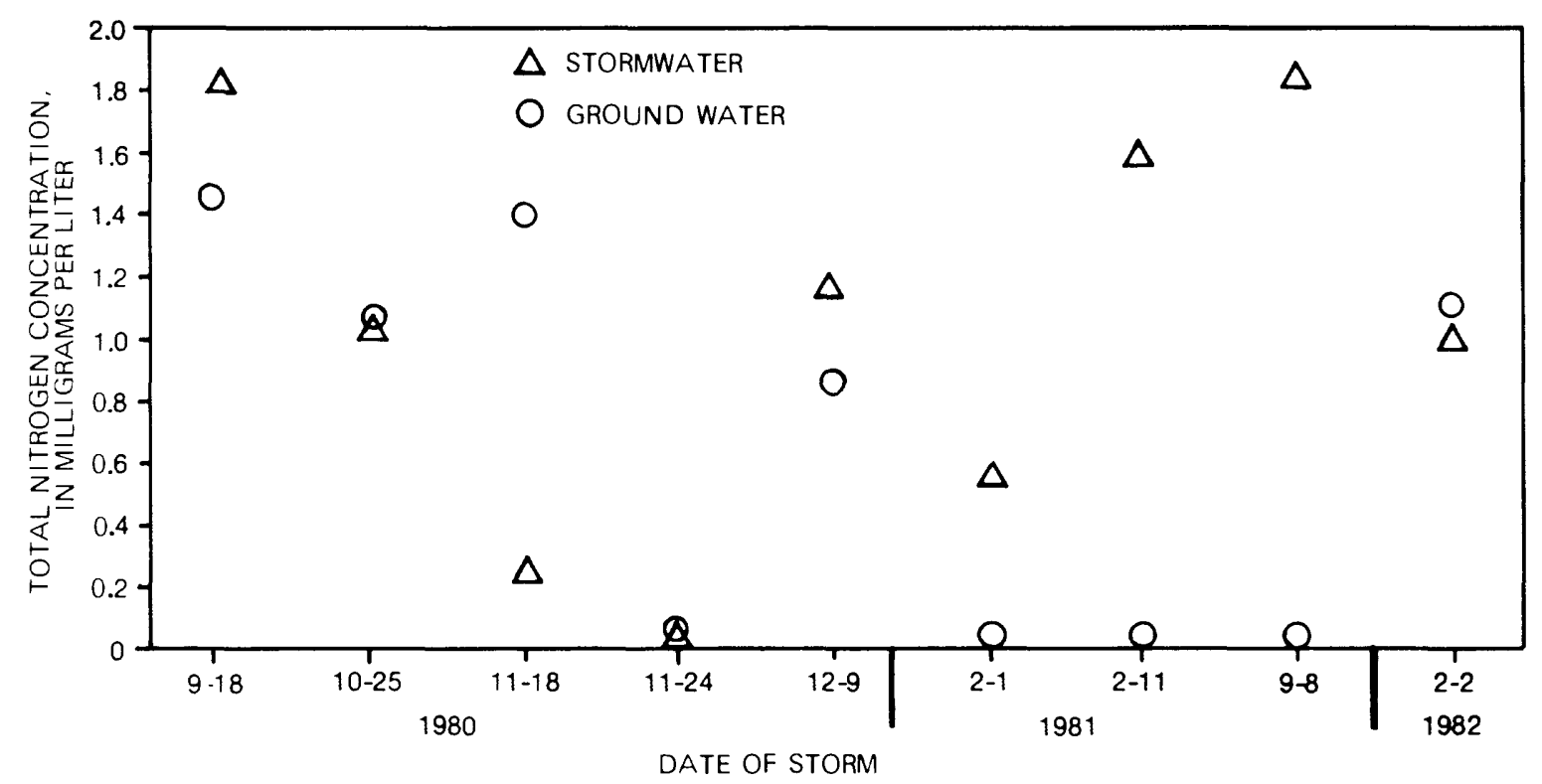

Figure 10.--Flow-weighted average concentrations of nitrogen in stormater and observed concentrations in ground water at Plainview, 1980-82. 
also occasionally greater than those in stormwater runoff. This indicates that the ground water sampled after a storm was not derived entirely from infiltrated stormwater produced by the immediately preceding storm, and that some mixing of the infiltrated stormwater with the shallow ground water inevitably occurred during collection of the ground-water sample. Therefore, ground-water constituent loads in table 17B should be regarded as a general, not absolute, indicator of the degree of constituent removal during infiltration.

The chloride load in stormwater in the strip-commercial and shoppingcenter recharge basins was sometimes extremely high, especially during winter--118 1b at Centereach on March 4, 1982; $1631 \mathrm{~b}$ at Huntington on February 19, 1981; and 1,558 1b at Huntington on January 23, 1982 (table 17B). The highway basin had the largest inflow of lead (2.03 $1 \mathrm{~b}$ at Plainview on February 11, 1981), followed by the strip commercial basin ( $1.051 \mathrm{~b}$ at Centereach on June 5, 1982). The low-density residential area at Laurel Hollow and the medium-density residential area at Syosset contributed relatively small loads of all four constituents.

These data suggest that land use is a major factor in constituent loading to the basins and that seasonal variability is also important.

\section{Priority Pollutants}

Loads of the priority pollutants were not computed because the concentrations of these constituents were obtained from single grab samples only.

\section{Bacteria}

The median and range of the three indicator bacteria in all sampled storms are given in table 18 in units of number of bacteria per acre of impervious area per inch of precipitation. Low-density residential (Laurel Hollow) and nonresidential (Huntington, Plainview) areas appear to contribute the least amount of bacteria to stormwater, whereas medium-density residential (Syosset) and strip commercial (Centereach) areas contribute the most.

As stated previously, flow data from the Huntington site were difficult to obtain because the electromagnetic flow sensor in the inflow pipe was of ten submerged and because reverse flow sometimes occurred in the pipe during storms. Even though the concentration of bacteria at Huntington (table 15) was relatively high, the calculated load of bacteria (table 18) was relatively low. It is therefore probable that the discharge volume used in computing bacteria loads at Huntington was lower than the actual value and that bacteria loads at that site are probably higher than those shown in table 15.

The median and range of the three indicator bacteria for all five sites are listed by season in table 19. Although the total coliforms show no significant difference between the warm and cool season, fecal coliforms and fecal streptococci in stormwater increase by one to two orders of magnitude during the warm season. This analysis is in agreement with the seasonal variations in indicator bacteria reported by Mallard (1980, p. 6). 
Table 17A.--Flow-weighted concentrations of selected constituents in stormater and observed concentrations in water reaching the water table at recharge basins.

[All values are in milligrams per liter. Site locations are shown in fig. 2]

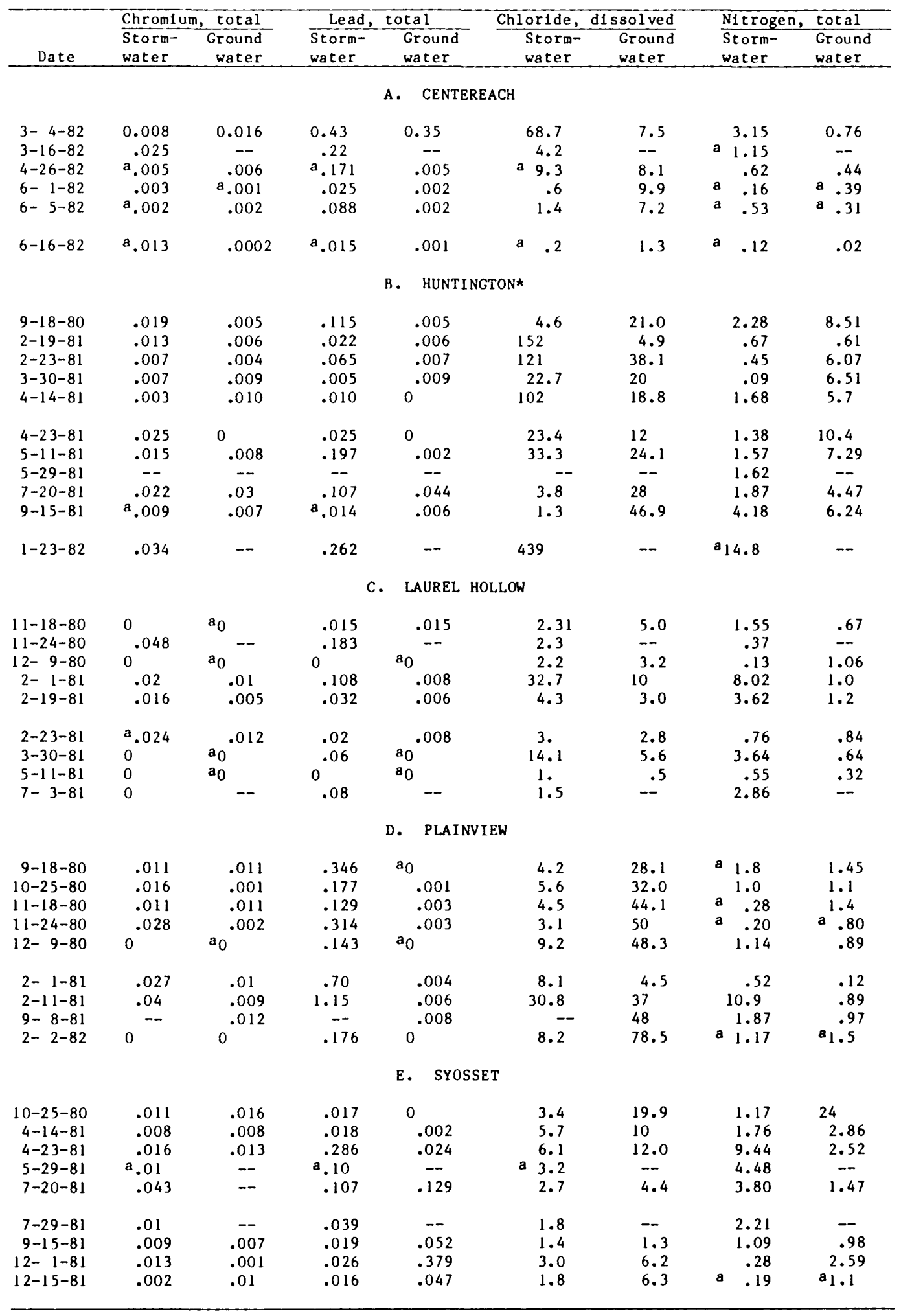

- data unavallable

a estimated value

* Because of difficulties in obtaining accurate runoff measurements at this site, all flow values are low and all flow-weighted concentrations are presumed to be underestimated. 
Table 178.--Loads of selected constituents in stormwater and in water reaching the water table at recharge basins.

[All values are in pounds. Site locations are shown in $\mathrm{f} 1 \mathrm{~g} .2$ ]

\begin{tabular}{|c|c|c|c|c|c|c|c|c|}
\hline \multirow[b]{2}{*}{ Date } & \multicolumn{2}{|c|}{ Chromium, total } & \multicolumn{2}{|c|}{ Lead, total } & \multicolumn{2}{|c|}{ Chloride, dissolved } & \multicolumn{2}{|c|}{ Nitrogen, total } \\
\hline & $\begin{array}{l}\text { Storm- } \\
\text { water }\end{array}$ & $\begin{array}{r}\text { Ground } \\
\text { water }\end{array}$ & $\begin{array}{l}\text { Storm- } \\
\text { water }\end{array}$ & $\begin{array}{l}\text { Ground } \\
\text { water }\end{array}$ & $\begin{array}{l}\text { Storm- } \\
\text { water }\end{array}$ & $\begin{array}{l}\text { Ground } \\
\text { water }\end{array}$ & $\begin{array}{l}\text { Storm- } \\
\text { water }\end{array}$ & $\begin{array}{l}\text { Ground } \\
\text { water }\end{array}$ \\
\hline \multicolumn{9}{|c|}{ A. CENTEREACH } \\
\hline $3-4-82$ & 0.015 & 0.027 & 0.740 & 0.710 & 118 & 12.8 & 5.40 & 1.30 \\
\hline $3-16-82$ & .012 & -- & .107 & -- & 2.05 & -- & a .549 & -- \\
\hline $4-26-82$ & a. 009 & .012 & a. 340 & .010 & $a_{18.5}$ & 16.1 & 1.23 & .873 \\
\hline $6-1-82$ & .010 & $a .004$ & .089 & .007 & 2.05 & 35.7 & a. .586 & $a_{1.41}$ \\
\hline $6-5-82$ & a.025 & .024 & 1.05 & .024 & 17.1 & 85.8 & $\mathrm{a}_{6} .30$ & $a_{3.69}$ \\
\hline $6-16-82$ & a. 152 & .002 & a. 173 & .007 & a 2.54 & 15.5 & $a_{1.40}$ & .251 \\
\hline \multicolumn{9}{|c|}{ B. HUNTINGTON* } \\
\hline $9-18-80$ & .004 & .001 & .024 & .001 & .958 & 4.37 & .474 & 1.77 \\
\hline $2-19-81$ & .014 & .006 & .024 & .006 & 163 & 5.30 & .720 & .650 \\
\hline $2-23-81$ & .003 & .002 & .028 & .003 & 51.6 & 16.3 & .192 & 2.60 \\
\hline $3-30-81$ & .004 & .005 & .003 & .005 & 13.1 & 11.5 & .050 & 3.75 \\
\hline $4-14-81$ & .001 & .003 & .003 & 0 & 29.2 & 5.47 & .483 & 1.64 \\
\hline $4-23-81$ & .001 & 0 & .001 & 0 & .949 & .811 & .056 & .422 \\
\hline $5-11-81$ & .010 & .005 & .129 & .001 & 21.8 & 15.8 & 1.03 & 4.78 \\
\hline $5-29-81$ & -- & -- & -- & -- & -- & - & 2.22 & -- \\
\hline $7-20-81$ & .021 & .029 & .103 & .042 & 3.73 & 26.9 & 1.80 & 4.30 \\
\hline $9-15-81$ & $a .066$ & .049 & a.099 & .042 & 9.06 & 238 & 29.2 & 43.6 \\
\hline $1-23-82$ & .120 & -- & .931 & -- & 1560 & -- & $a_{52.7}$ & -- \\
\hline \multicolumn{9}{|c|}{ C. LAUREL HOLLOW } \\
\hline $11-18-80$ & 0 & $a_{0}$ & .002 & .002 & .309 & .668 & .207 & .090 \\
\hline $11-24-80$ & .025 & -- & 0.096 & -- & 1.2 & -- & .192 & -- \\
\hline $12-9-80$ & 0 & $a_{0}$ & 0 & $a_{0}$ & .017 & .024 & .001 & .008 \\
\hline $2-1-81$ & .008 & .004 & .041 & .003 & 12.4 & 3.79 & 3.04 & .375 \\
\hline $2-19-81$ & .010 & .003 & .021 & .004 & 2.75 & 1.93 & 2.33 & .771 \\
\hline $2-23-81$ & a. .006 & .003 & .005 & .002 & .760 & .688 & .187 & .206 \\
\hline $3-30-81$ & 0 & $a_{0}$ & .004 & $a_{0}$ & .883 & .350 & .227 & .040 \\
\hline $5-11-81$ & 0 & $a_{0}$ & 0 & $a_{0}$ & .041 & .020 & .021 & .016 \\
\hline $7-3-81$ & 0 & -- & .015 & -- & .284 & -- & .542 & - \\
\hline \multicolumn{9}{|c|}{ D. PLAINVIEW } \\
\hline $9-18-80$ & .001 & .001 & .030 & $a_{0}$ & .364 & 2.44 & a. .154 & .126 \\
\hline $10-25-80$ & .027 & .002 & .305 & .002 & 9.66 & 55.2 & 1.72 & 1.90 \\
\hline $11-18-80$ & .016 & .015 & .176 & .005 & 6.1 & 60.0 & a. 385 & 1.9 \\
\hline $11-24-80$ & .095 & .007 & 1.08 & .010 & 10.8 & 172 & a .696 & $a_{2.75}$ \\
\hline $12-9-80$ & 0 & $a_{0}$ & .001 & $a_{0}$ & .064 & .388 & .008 & .006 \\
\hline $2-1-81$ & .044 & .017 & 1.16 & .007 & 13.4 & 7.45 & .859 & .199 \\
\hline $2-11-81$ & .071 & .016 & 2.03 & .01 & 54.5 & 65.3 & 19.2 & 1.58 \\
\hline $9-8-81$ & -- & .016 & -- & .011 & -- & 65.3 & 2.55 & 1.32 \\
\hline $2-2-82$ & 0 & 0 & .88 & 0 & 41.0 & 392 & a 5.90 & $a_{7} .60$ \\
\hline \multicolumn{9}{|c|}{ E. SYOSSET } \\
\hline $10-25-80$ & .008 & .012 & .013 & 0 & 2.63 & 15.3 & .895 & 18.4 \\
\hline $4-14-81$ & .005 & .005 & .012 & .001 & 3.72 & 6.51 & 1.14 & 1.86 \\
\hline $4-23-81$ & .010 & .008 & .175 & .015 & 3.73 & 7.34 & 5.77 & 1.54 \\
\hline $5-29-81$ & a. 007 & -- & $a .068$ & -- & a 2.30 & - & 3.19 & - \\
\hline $7-20-81$ & .030 & -- & .075 & .090 & 1.89 & 3.10 & 2.66 & 1.03 \\
\hline $7-29-81$ & & -- & .004 & -- & .179 & -- & .226 & -- \\
\hline $9-15-81$ & .017 & .014 & .037 & .103 & 2.67 & 2.56 & 2.16 & 1.93 \\
\hline$|2-1-8|$ & .028 & .002 & .056 & .803 & 6.37 & 13.1 & .593 & 5.49 \\
\hline $12-15-81$ & .003 & .017 & .028 & .081 & 3.12 & 10.9 & a. .323 & $a_{1.89}$ \\
\hline
\end{tabular}

- data unava1lable

a estimated value

* Because of difficulties in obtaining accurate runoff measurements at this site, all flow values are low and all load values are presumed to be underestimated. 
Table 18.--Minimum, maximum, and median number of bacteria per storm for all sampled storms, per acre per inch of precipitation.

[Locations are shown in fig. 2.]

\begin{tabular}{|c|c|c|c|}
\hline Bacteria & Minimum & Maximum & Median \\
\hline \multicolumn{4}{|c|}{ Centereach } \\
\hline $\begin{array}{l}\text { Total coliforms } \\
\text { Fecal coliforms } \\
\text { Fecal streptococci }\end{array}$ & $\begin{array}{l}1.1 \times 10^{9} \\
8.2 \times 10^{8} \\
3.4 \times 10^{9}\end{array}$ & $\begin{array}{l}2.2 \times 10^{11} \\
7.5 \times 10^{10} \\
9.4 \times 10^{10}\end{array}$ & $\begin{array}{l}1.2 \times 10^{10} \\
1.5 \times 10^{9} \\
3.7 \times 10^{10}\end{array}$ \\
\hline \multicolumn{4}{|c|}{ Huntington } \\
\hline $\begin{array}{l}\text { Total coliforms } \\
\text { Fecal coliforms } \\
\text { Fecal streptococci }\end{array}$ & $\begin{array}{l}1.0 \times 10^{8} \\
1.5 \times 10^{8} \\
4.8 \times 10^{7}\end{array}$ & $\begin{array}{l}7.1 \times 10^{10} \\
1.2 \times 10^{10} \\
9.4 \times 10^{10}\end{array}$ & $\begin{array}{l}2.8 \times 10^{9} \\
5.6 \times 10^{8} \\
9.7 \times 10^{9}\end{array}$ \\
\hline \multicolumn{4}{|c|}{ Laurel Hollow } \\
\hline $\begin{array}{l}\text { Total coliforms } \\
\text { Fecal coliforms } \\
\text { Fecal streptococci }\end{array}$ & $\begin{array}{l}1.4 \times 10^{7} \\
1.6 \times 10^{6} \\
2.4 \times 10^{8}\end{array}$ & $\begin{array}{l}7.0 \times 10^{9} \\
4.3 \times 10^{9} \\
8.9 \times 10^{10}\end{array}$ & $\begin{array}{l}5.1 \times 10^{8} \\
1.0 \times 10^{8} \\
3.0 \times 10^{9}\end{array}$ \\
\hline \multicolumn{4}{|c|}{ Plainview } \\
\hline $\begin{array}{l}\text { Total coliforms } \\
\text { Fecal coliforms } \\
\text { Fecal streptococci }\end{array}$ & $\begin{array}{l}1.3 \times 10^{7} \\
3.4 \times 10^{6} \\
1.3 \times 10^{8}\end{array}$ & $\begin{array}{l}5.3 \times 10^{10} \\
5.2 \times 10^{9} \\
1.3 \times 10^{11}\end{array}$ & $\begin{array}{l}1.7 \times 10^{8} \\
7.4 \times 10^{8} \\
1.2 \times 10^{10}\end{array}$ \\
\hline \multicolumn{4}{|c|}{ Syosset } \\
\hline $\begin{array}{l}\text { Total coliforms } \\
\text { Fecal coliforms } \\
\text { Fecal streptococci }\end{array}$ & $\begin{array}{l}8.4 \times 10^{8} \\
4.2 \times 10^{8} \\
8.0 \times 10^{9}\end{array}$ & $\begin{array}{l}2.1 \times 10^{11} \\
4.4 \times 10^{10} \\
3.2 \times 10^{11}\end{array}$ & $\begin{array}{l}3.0 \times 10^{10} \\
7.5 \times 10^{9} \\
4.6 \times 10^{10}\end{array}$ \\
\hline
\end{tabular}

Table 19.--Seasonal comparison of minimum, maximum, and median number of bacteria per storm for all sampled storms, per acre per inch of precipitation.

Bacteria Minimum Maximum Median

A. Cool Season (October through March)

\begin{tabular}{lccccc} 
Total coliforms & $1.3 \times 10^{7}$ & $7.4 \times 10^{11}$ & $1.9 \times 10^{9}$ \\
Fecal coliforms & $1.6 \times 10^{6}$ & $5.2 \times 10^{9}$ & $6.1 \times 10^{8}$ \\
Fecal streptococci & $1.3 \times 10^{8}$ & $1.2 \times 10^{11}$ & $8.0 \times 10^{9}$ \\
\multicolumn{7}{c}{ B. Warm Season (April } & through September) & \\
\multicolumn{7}{c}{ Total coliforms } & $7.1 \times 10^{7}$ & $2.2 \times 10^{11}$ & $2.3 \times 10^{9}$ \\
Fecal collforms & $1.5 \times 10^{6}$ & $7.5 \times 10^{10}$ & $1.2 \times 10^{10}$ \\
Fecal streptococci & $4.8 \times 10^{7}$ & $3.2 \times 10^{11}$ & $4.2 \times 10^{10}$ \\
\hline
\end{tabular}




\section{REMOVAL OF CHEMICAL CONSTITUENTS OF RUNOFF BY SOILS}

To investigate the removal of stormwater constituents by soil during infiltration, basin-bottom soil samples were collected from the Huntington, Laurel Hollow, Plainview, and Syosset basins on June 5, 1981 for metals and pesticide analysis. (Sampling at Centereach was not begun until 1982.)

The soil samples were collected at two arbitrarily chosen spots approximately $5 \mathrm{ft}$ from the concrete apron at the end of the basin inflow pipe. Because the basin at Huntington contains at least $2 \mathrm{ft}$ of water at all times, the soil was taken from two points just above the water line at the base of the service ramp. Each sample was taken from the top few inches of soil. Samples for pesticide analysis were placed in a pretreated 1-liter glass jar with a Teflon seal; those for metals analysis were placed in 1-liter plastic containers. The samples were sent to the U.S. Geological Survey sediment laboratory for analysis. The results of these analyses are shown in table 20 .

\section{Metals}

Chromium concentrations (table 20) ranged from $10 \mu \mathrm{g} / \mathrm{g}$ to $20 \mu \mathrm{g} / \mathrm{g}$. Lead concentrations ranged from a low of $70 \mathrm{\mu g} / \mathrm{g}$ at Laurel Hollow to a high of $1,200 \mu \mathrm{g} / \mathrm{g}$ at Plainview. The other metals found in significant concentrations--iron, manganese, and zinc--are native to the soil ( $\mathrm{Ku}$ and others, 1978).

The concentration of chromium in basin-bottom soil seems fairly uniform (20 $\mathrm{\mu g} / \mathrm{g}$ at Huntington, $10 \mathrm{\mu g} / \mathrm{g}$ at Laurel Hollow, Plainview, and Syosset). The highest chromium concentration, $20 \mathrm{\mu g} / \mathrm{g}$ at Huntington, is near the 19 $\mathrm{mg} / \mathrm{kg}$ that was theorized by $\mathrm{Ku}$ and others (1978) to represent the maximum sorption capacity of the soil. (Soil containing that concentration of chromium was found near the source of a chromium-rich plume from a metal-plating plant that had been discharging effluent to disposal basins for more than 30 years.) This is not certain, however, because sorption capacity varies with soil properties such as grain size and lithology (Ku and others, 1978).

The concentration of lead was highest $(1,200 \mu \mathrm{g} / \mathrm{g})$ at the Plainview basin, which receives storm runoff from a highway, and lowest $(70 \mathrm{\mu g} / \mathrm{g})$ at the Laurel Hollow basin, which is newer (1979) and drains a low-density residential area. These findings support the assumption that the metals in the dissolved form are probably removed from stormwater by adsorption onto near-surface soil particles in the unsaturated zone and that those in particulate form are simply filtered out by the soil.

\section{Pesticides}

These substances (table 20) are used by local residents, exterminators, and government agencies, especially during spring and early summer. They are generally nearly insoluble in water but are moderately to freely soluble in organic solvents. They can enter recharge basins mixed with water or sorbed on sediment particles and can also enter as dry fallout. 
The time required for total decomposition of these compounds in soil and water ranges from days to many years. Breakdown and mechanical dispersion rates depend on such factors as temperature, light, humidity, air movement, volatility of the compounds, and especially microbiologic activity (Seaburn and Aronson, 1974).

Table 20.--Concentrations of metals, pesticides, and polychlorinated aromatic hydrocarbons in basin soil samples, June 1981.

[So11 samples collected on June 5, 1981. All concentrations are in $(\mu \mathrm{g} / \mathrm{kg})$. Site locations are shown in $\mathrm{f} 1 \mathrm{~g} .2 \mathrm{l}$

\begin{tabular}{lrrrr}
\hline \multicolumn{1}{c}{ Substance } & Huntingtion & Laurel Hollow & Pla1nview & Syoss \\
\hline Metals & & & & \\
Arsenic & & & & \\
Cadmium & 0 & 0 & 0 & 0 \\
Chromium & 0 & 2 & 2 & 2 \\
Copper & 20 & 10 & 10 & 10 \\
Iron & 8 & 8 & 28 & 25 \\
Lead & 4,900 & 4,700 & 8,300 & 4,000 \\
Manganese & 89 & 70 & 1,200 & 550 \\
Mercury & 41 & 97 & 93 & 85 \\
Zinc & 0 & 0 & 0 & 0 \\
& 35 & 18 & 130 & 132
\end{tabular}

Pesticides and polychlorinated aromat 1c hydrocarbons

\begin{tabular}{|c|c|c|c|c|}
\hline Aldrin & $<0.1$ & $<0.1$ & $<0.1$ & $<0.1$ \\
\hline Chlordane & 14 & $<1$ & 270 & 2,700 \\
\hline DDD & 71 & $<0.1$ & $<0.1$ & $<0.1$ \\
\hline DDE & 2.1 & 1.5 & $<0.1$ & 0.0 \\
\hline DDT & 7.1 & 31 & 71 & 1,400 \\
\hline Diazinon & $<0.1$ & 0.1 & 1.6 & 18 \\
\hline Dieldrin & 0.6 & 0.1 & 5.8 & 15 \\
\hline Endosulfan & $<0.1$ & $<0.1$ & 11 & $<0.1$ \\
\hline Endrin & $<0.1$ & $<0.1$ & $<0.1$ & $<0.1$ \\
\hline Ethion & $<0.1$ & $<0.1$ & $<0.1$ & $<0.1$ \\
\hline Gross PCB & 16 & 2 & 100 & $<1$ \\
\hline Gross PCN & $<1$ & $<1$ & $<1$ & $<1$ \\
\hline Heptachlor epoxide & $<0.1$ & $<0.1$ & $<0.1$ & 24 \\
\hline Heptachlor & $<0.1$ & $<0.1$ & $<0.1$ & $<0.1$ \\
\hline Lindane & $<0.1$ & $<0.1$ & $<0.1$ & $<0.1$ \\
\hline Malathion & $<0.1$ & $<0.1$ & $<0.1$ & $<0.1$ \\
\hline Methyl trithion & $<0.1$ & $<0.1$ & $<0.1$ & $<0.1$ \\
\hline Methylparathion & $<0.1$ & $<0.1$ & $<0.1$ & $<0.1$ \\
\hline Mirex & $<0.1$ & $<0.1$ & $<0.1$ & $<0.1$ \\
\hline Methoxychlor & $<0.1$ & $<0.1$ & $<0.1$ & $<0.1$ \\
\hline Parathion & $<0.1$ & $<0.1$ & $<0.1$ & $<0.1$ \\
\hline Perthane & $<0.1$ & $<0.1$ & $<0.1$ & $<0.1$ \\
\hline Silvex & 0 & 0 & 0 & 0 \\
\hline Toxaphene & $<1$ & $<1$ & $<1$ & $<1$ \\
\hline Trithion & $<0.1$ & $<0.1$ & $<0.1$ & $<0.1$ \\
\hline $2,4-D$ & 0 & 0 & 0 & 0 \\
\hline $2,4-D P$ & 0 & 0 & 0 & 0 \\
\hline $2,4,5-T$ & 0 & 0 & 0 & 0 \\
\hline
\end{tabular}


Most of the 28 pesticides and polychlorinated aromatic hydrocarbons for which samples were analyzed were either not present or were below detectable limits. The exceptions were chlordane, DDD, DDE, DDT, diazinon, dieldrin, endosulfan, gross PCB, and heptachlor epoxide; these were found in concentrations ranging from $0.6 \mu \mathrm{g} / \mathrm{kg}$ (dieldrin at Huntington) to $2,700 \mu \mathrm{g} / \mathrm{kg}$ (chlordane at Syosset). However, concentrations in stormwater and groundwater samples were below detectable limits in all but two instances, where total pesticide concentrations were less than $0.2 \mu \mathrm{g} / \mathrm{L}$. (See appendix $\mathrm{B}$ and table 13B.)

These results are supported by a similar study by Seaburn and Aronson (1974), who found low concentrations (up to $0.08 \mu \mathrm{g} / \mathrm{L}$ ) of DDD, DDT, and silvex in stormwater and much higher concentrations in basin soil. For example, the DDT content of soil from each of the three basins they sampled ranged from 18,000 to 300,000 times the concentration in stormwater inflow.

The presence of pesticides in basin soil in concentrations several orders of magnitude higher than those in inflow samples indicates that the pesticides are probably sorbed or filtered out in the soil layer and effectively removed from the infiltrating water (Seaburn and Aronson, 1974). Also, because the use of some pesticides has been curtailed in recent years, most of the pesticides in basin soil are probably derived from past use.

\section{SUMMARY AND CONCLUSIONS}

Recharge basins have been used on Long Island since 1935 to collect urban storm runoff and to recharge the ground-water reservoir, which is the sole source of public supply for the residents of Nassau and Suffolk Counties. The Long Island Comprehensive Waste Treatment Management Study (Koppelman, 1978) implicated recharge basins as a possible major cause of ground-water contamination and suggested that they may concentrate undesirable urban runoff constituents and convey them to the underlying aquifers.

The objectives of this study, which was conducted during 1979-83 as part of the U.S. Environmental Protection Agency's Nationwide Urban Runoff Program, were to:

1. determine the source, type, quantity, and fate of contaminants in urban stormwater runof $f$; and

2. assess the effects of runoff on the chemical and microbiological quality of ground-water beneath the basins.

Forty-six storms at five recharge basins in representative land-use areas (strip commercial, shopping-mall parking lot, major highway, low-density residential, and medium-density residential) were monitored. Modified runoff/ precipitation ratios indicate that all storm runoff consists of precipitation that falls on impervious surfaces in the drainage area except during storms of high intensity or long duration. 
Samples were analyzed for standard constituents (listed in appendix A), heavy metals, organic compounds, and bacteria. In addition, soll and snow samples were collected to investigate the removal of selected stormwater constituents by soil during infiltration and the accumulation of some of these constituents on snow cover.

Concentrations of most measured constituents in individual stormwater samples were within Federal and State drinking-water standards. Exceptions were attributed to specific land uses and seasonal effects. Lead was present in highway runoff in concentrations up to $3,300 \mu \mathrm{g} / \mathrm{L}$, and chloride in parking lot runoff was detected in concentrations up to $1,100 \mathrm{mg} / \mathrm{L}$ during winter, when salt is used for deicing.

Most of the load of heavy metals was removed during infiltration through the unsaturated zone, but neither nitrogen nor chloride was removed. Nitrogen concentrations in ground water of ten exceeded those in stormwater because the ground water contains nitrogen from other sources, including cesspools, septic tanks, and lawn fertilizers.

of the five stormwater and nine ground-water samples that were analyzed for 113 USEPA-designated "priority pollutants," three contained a total of four constituents in concentrations exceeding New York State guidelines for a single organic compound in drinking water--namely, p-chloro-m-cresol (79 $\mu \mathrm{g} / \mathrm{L})$ and 2,4-dimethylphenol $(96 \mathrm{\mu g} / \mathrm{L})$ in ground water at the highway basin; 4-nitrophenol $(58 \mu \mathrm{g} / \mathrm{L})$ in ground water at the parking lot basin; and methylene chloride $(230 \mu \mathrm{g} / \mathrm{L})$ in stormwater at the highway basin. These samples also contained a combination of substances exceeding the guidelines for total organic constituents in drinking water. The presence of these constituents is attributed to point sources rather than to urban runoff; they are unrelated to the land use in the drainage area.

The median number of indicator bacteria in stormwater ranged from $10^{8}$ to $10^{10} \mathrm{MPN} / 100 \mathrm{~mL}$. Fecal coliforms and fecal streptococci increased by 1 to 2 orders of magnitude during the warm season, but total coliform concentrations showed no significant seasonal differences.

Low-density residential and nonresidential (highway and parking lot) areas seemed to contribute the fewest bacteria to stormwater, and mediumdensity residential and strip commercial areas contributed the most. Virtually no bacteria were detected in the ground water beneath the recharge basins, which indicates complete removal during the infiltration of stormwater through the unsaturated zone.

Concentrations of lead in basin-bottom soil samples (70 $\mathrm{\mu g} / \mathrm{g}$ at the lowdensity residential basin; $1,200 \mu \mathrm{g} / \mathrm{g}$ at the highway basin) reflect the land use in the drainage area and support the assumption that the metals dissolved in runoff are removed by adsorption onto near-surface soil particles in the unsaturated zone, and that those in particulate form are filtered out by the soil during infiltration.

Concentrations of pesticides in basin-bottom soll samples were generally much higher than those in stormwater, ranging from $0.6 \mathrm{\mu g} / \mathrm{kg}$ (dieldrin at the shopping-center basin) to $2,700 \mu \mathrm{g} / \mathrm{kg}$ (chlordane at the medium-density residential basin). This suggests that the pesticides are probably sorbed or 
filtered out in the soil layer and are effectively removed from infiltrating water. Also, because pesticide use has been curtailed in recent years, most of the pesticides in basin soil are probably derived from past use.

In terms of the chemical and microbiological constituents of stormwater studied, the use of recharge basins on Long Island to dispose of storm runof $f$ and to recharge the ground water does not appear to have significant adverse effects on ground-water quality.

\section{REFERENCES CITED}

Aronson, D. A., and Seaburn, G. E., 1974, Appraisal of the operating efficiency of recharge basins on Long Island, New York, in 1969: U.S. Geological Survey Water-Supply Paper 2001-D, p. D1-D22.

Brashears, M. L., Jr., 1946, Artificial recharge of ground water on Long Island, New York: Economic Geology, v. 41, no. 5, p. 503-516.

Brice, H. D., Whitaker, C. L., and Sawyer, R. M., 1959, A progress report on the disposal of storm water at an experimental seepage basin near Mineola, New York: U.S. Geological Survey Open-File Report, 56 p.

Cobb, E. D., and Bailey, J. F., 1965, Measurement of discharge by dye dilution methods--hydraulic measurement and computation: U.S. Geological Survey Surface Water Techniques, book 1, chapter 14, 27 p.

Cohen, Philip, Franke, O. L., and Foxworthy, B. L., 1968, An atlas of Long Island's water resources: New York State Water Resources Commission Bulletin 62, $117 \mathrm{p}$.

E11is, Sherman R., and Alley, William M., 1979, Quantity and quality of urban runoff from three localities in the Denver metropolitan area, Colorado: U.S. Geological Survey Water-Resources Investigations 79-64, 60 p.

Geldreich, E. E., and Kenner, B. A., 1969, Concepts of fecal streptococci in stream pollution: Journal of Water Pollution Control Federation, v. 41, p. R336-R352.

Holzmacher, B. G., McLendon, S. C., and Murre11, N. E., 1970, Comprehensive public water-supply study, Suffolk County, New York: Melville, N.Y., Holzmacher, McLendon, and Murrel1, Inc., v. II, p. 164-172.

Koszalka, E. J., 1975, The water table on Long Island, New York, in March 1974: Suffolk County Water Authority, Long Island Water Resources Bulletin 5, 7 p.

Koppelman, L. E., 1978, The Long Island comprehensive waste treatment management plan: Nassau-Suffolk Regional Planning Board, v. 2., 364 p.

1982, The Long Island segment of the Nationwide Urban Runoff

Program: Long Island Regional Planning Board, Hauppauge, N.Y., 134 p. 


\section{REFERENCES CITED (Continued)}

Ku, H. F. H., Katz, B. G., Sulam, D. J., and Krulikas, R. K., 1978, Scavenging of chromium and cadmium by aquifer material--South Farmingdale-Massapequa area, Long Island, New York: Ground Water, v. 16, no. 2, p. 112-118.

$\mathrm{Ku}, \mathrm{H}$. F. H., and Sulam, D. J., 1979, Hydrologic and water-quality appraisal of southeast Nassau County, Long Island, New York: Long Island Water Resources Bulletin 13, 129 p.

Lounsbury, Clarence, Howe, F. B., Zautner, R. E., Moran, W. J., and Beers, P. D., 1928, Soil survey of Suffolk and Nassau Counties, New York:

U.S. Department of Agriculture, Bureau of Chemistry and Soils, ser. 1928, no. 28,46 p.

Mallard, G. E., 1980, Microorganisms in stormwater--a summary of recent investigations: U.S. Geological Survey Open-File Report 80-1198, 18 p.

McClymonds, N. E., and Franke, O. L., 1972, Water-transmitting properties of aquifers on Long Island, New York: U.S. Geological Survey Professional Paper 627-E, 24 p.

Miller, J. F., and Frederick, R. H., 1969, The precipitation regime of Long Island, New York: U.S. Geological Survey Professional Paper 627-A, p. A1-A21.

Miller, T. L., and McKenzie, S. W., 1978, Analysis of urban storm-water quality from seven basins near Portland, Oregon: U.S. Geological Survey Open-File Report 78-662, 47 p.

New York State Department of Environmental Conservation, 1977, Proposed ground water classifications, quality standards, and effluent standards and/or limitations: Title 6, Official Compilation of Codes, Rules and Regulations of the State of New York, Part 703, 11 p.

Parker, G. G., Cohen, Philip, and Foxworthy, B. L., 1967, Artificial recharge and its role in scientific water management, with emphasis on Long Island, New York, in Miguel Marino, ed., Symposium on ground-water hydrology, San Francisco, California, 1967: American Water Resources Association, Proceedings. Series 4, p. 193-213.

Pluhowski, E. J., and Kantrowitz, I. H., 1964, Hydrology of the Babylon-Islip area, Suffolk County, Long Island, New York: U.S. Geological Survey Water-Supply Paper 1768, 119 p.

Pluhowski, E. J., and Spinello, A. G., 1978, Impact of sewerage systems on stream base flow and ground-water recharge on Long Island, New York: U.S. Geological Survey Journal of Research, v. 6, no. 2, p. 263-271.

Seaburn, G. E., 1969, Effects of urban development on direct runoff to East Meadow Brook, Nassau County, Long Island, New York, in U.S. Geological Survey Professional Paper 627-B, p. B1-B14. 


\section{REFERENCES CITED (Continued)}

Seaburn, G. E., 1970a, Preliminary analysis of rate of movement of storm runoff through the zone of aeration beneath a recharge basin on Long Island, New York, in Geological Survey Research, 1970, Chapter B: U.S. Geological Survey Professional Paper 700-B, p. B196-B198.

, 1970b, Preliminary results of hydrologic studies at two recharge basins on Long Island, New York, in U.S. Geological Survey Professional Paper $627-\mathrm{C}$, p. $\mathrm{C} 1-\mathrm{C} 17$.

Seaburn, G. E., and Aronson, D. A., 1973, Catalog of recharge basins on Long Island, New York, in 1969: New York State Department of Environmental Conservation Bulletin 70, 80 p.

, 1974, Influence of recharge basins on the hydrology of Nassau and Suffolk Counties, Long Island, New York: U.S. Geological Survey Water-Supply Paper 2031, 66 p.

Simmons, D. L., and Reynolds, R. J., 1982, Effects of urbanization on base flow of selected south-shore streams, Long Island, New York: Water Resources Bulletin, v. 18, no. 5, p. 797-805.

U.S. Bureau of the Census, 1982,1980 census of population: U.S. Department of Commerce, v. 1, chapter A, part 34.

U.S. Public Health Service, 1962, Public Health Service drinking-water standards, 1962: U.S. Public Health Service Publication 956, 61 p.

U.S. Environmental Protection Agency, 1973, Water quality criteria, 1972: U.S. Environmental Protection Agency Ecological Research Series, EPA-R3-73-033, 594 p.

, 1976, National interim primary drinking water regulations: U.S. Environmental Protection Agency, EPA-570/9-76-003, 159 p.

Versar, Inc., 1980, Monitoring of toxic pollutants in urban runoff--a guidance manual: Springfield, Va., Versar, Inc., interim final report, 85 p.

, 1982, Nationwide urban runoff program (NURP)--report of analytical data (five samples) for the Long Island, New York NURP study area: Springfield, Va., Versar, Inc.

Wanielista, M. P., 1978, Stormwater management--quantity and quality: Ann Arbor, Mich., Ann Arbor Science, Inc., 383 p. 
Appendix A.--Standard chemical analysis.

\begin{tabular}{|c|c|}
\hline $\begin{array}{l}\text { Arsenic, dissolved } \\
\text { Arsenic, suspended } \\
\text { Arsenic, total } \\
\text { Cadmium, dissolved } \\
\text { Cadmium, suspended } \\
\text { Cadmium, total } \\
\text { Calcium, dissolved } \\
\text { Carbon, organic dissolved } \\
\text { Carbon, organic suspended } \\
\text { Chloride, dissolved } \\
\text { Chromium, dissolved } \\
\text { Chromium, suspended } \\
\text { Chromium, total } \\
\text { CoD (chemical oxygen demand) } \\
\text { Color } \\
\text { Fluoride, dissolved } \\
\text { Hardness, total } \\
\text { Lead, dissolved } \\
\text { Lead, suspended }\end{array}$ & 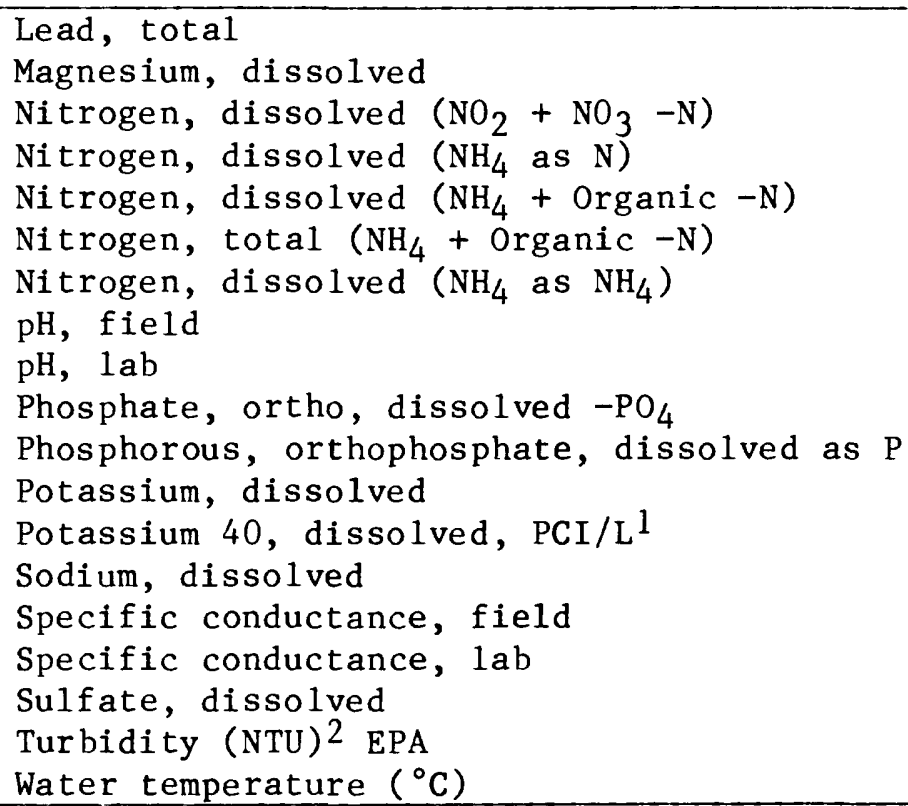 \\
\hline
\end{tabular}

1 Picocuries per liter

2 Nephelometric Turbidity Units

Appendix B.--U.S. Environmental Protection Agency Priority Pollutants.

BASE/NEUTRAL-EXTRACTABLE COMPOUNDS

acenaphthene

benzidine

1,2,4-trich1orobenzene

hexachlorobenzene

hexachloroethane

bis (2-chloroethy1) ether

2 -ch1oronapthalene

1,2-dichlorobenzene

1,3-dichlorobenzene

1,4-dich1orobenzene

$3,3^{\prime}$-dichlorobenzidine

2,4-dinitrotoluene

2,6-dinitrotoluene

1,2-diphenylhydrazine

(as azobenzene)

fluoranthene

4-chlorophenyl phenyl ether

4-bromophenyl phenyl ether

bis (2-chloroisopropyl) ether

bis (2-chloroethoxy) methane

hexachlorobutadiene

hexachlorocyclopentadiene

i sophorone

naphthalene nitrobenzene

$\mathrm{N}$-nitrosodime thyl ami ne

$\mathrm{N}$-nitrosodi phenylami ne

$\mathrm{N}$-nitrosodi-n-propylamine

bis (2-ethylhexyl) phthalate

butyl benzyl phthalate

di-n-butyl phthalate

di-n-octyl phthalate

diethyl phthalate

dimethy 1 phthalate

benzo (a) anthracene

benzo (a) pyrene

3,4-benzof luoranthene

benzo (k) fluoranthene

chrysene

acenaph thylene

anthracene

benzo $(g, h, i)$ perylene

fluorene

phenanthrene

dibenzo ( $a, b)$ anthracene

indeno $(1,2,3-c d)$ pyrene

pyrene

$2,3,7,8$-tetrachlorodibenzo-p-dioxin 
Appendix B.--U.S. Environmental Protection Agency Priority Pollutants. (continued)

VOLATILE ORGANIC COMPOUNDS

acrolein

acrylonitrile

benzene

carbon tetrachloride

chlorobenzene

1,2-dichloroethane

$1,1,1-$ trichloroethane

1,1-dichloroethane

$1,1,2-t$ richloroethane

$1,1,2,2$-tetrachloroethane

chloroethane

bis (chloromethyl) ether

2-chloroethylvinyl ether

chl orof orm

1,1-dichloroethylene

ACID-EXTRACTABLE COMPOUNDS

2,4,6-trichlorophenol

p-chloro-m-cresol

2-chlorophenol

2,4-di chlorophenol

2,4-dime thy 1 pheno1 1,2-trans-dichloroethylene

1,2-dichloropropane

1,3-dichloropropylene

ethyl benzene

methylene chloride

methyl bromide

bromoform

dich1orobromome thane

trichlor of luo rome thane

dichlorodifluo rome thane

chlorodibromome thane

tetrachloroe thylene

toluene

trichloroethylene

vinyl chloride

2-nitrophenol

4-nit ropheno1

2,4-dinitropheno1

4,6-dinitro-o-cresol

pentach1orophenol

phenol

\section{PESTICIDES}

aldrin

dieldrin

chlordane

4, $4^{\prime}$-DDT

4, $4^{\prime}$-DDE

4, $4^{\prime}-\mathrm{DDD}$

alpha-endosulfan

beta-endosulfan

endosulfan sulfate

endrin

endrin aldehyde

heptachlor

heptachlor epoxide 
Appendix C.--Data-retrieval information.

The following station-identification numbers can be used to retrieve stormwater flow and quality data, ground-water quality data, and precipitation quality data from the U.S. Geological Survey WATSTORE and EPA STORET data bases:

\begin{tabular}{|c|c|c|}
\hline Site & Station Number & Sample Type \\
\hline Centereach & $\begin{array}{l}405135073055101 \\
405135073055102 \\
405135073055103 \\
405135073055104\end{array}$ & $\begin{array}{l}\text { storm water } \\
\text { ground water } \\
\text { ground water } \\
\text { precipitation }\end{array}$ \\
\hline Huntington & $\begin{array}{l}404932073243701 \\
404932073243702 \\
404932073243704\end{array}$ & $\begin{array}{l}\text { storm water } \\
\text { ground water } \\
\text { precipitation }\end{array}$ \\
\hline Laure1 Ho11ow & $\begin{array}{l}405124073292601 \\
405124073292602 \\
405124073292604\end{array}$ & $\begin{array}{l}\text { storm water } \\
\text { ground water } \\
\text { precipitation }\end{array}$ \\
\hline Plainview & $\begin{array}{l}404713073273001 \\
404713073273002 \\
404713073273004\end{array}$ & $\begin{array}{l}\text { storm water } \\
\text { ground water } \\
\text { precipitation }\end{array}$ \\
\hline Syosset & $\begin{array}{l}404815073294601 \\
404815073294603 \\
404815073294604\end{array}$ & $\begin{array}{l}\text { storm water } \\
\text { ground water } \\
\text { precipitation }\end{array}$ \\
\hline
\end{tabular}


Appendix D.-Drinking-water standards of New York State, U.S. Public Health Service, and U.S. Environmental Protection Agency.

[Values for inorganic chemical constituents are in $\mathrm{mg} / \mathrm{L}$;

values for organic chemicals and pesticides are in $\mu \mathrm{g} / \mathrm{L}$ ]

\begin{tabular}{cccc}
\hline & $\begin{array}{c}\text { Proposed New } \\
\text { York State } \\
\text { Drinking Water } \\
\text { Standards } \\
(1977)^{\mathrm{a}}\end{array}$ & $\begin{array}{c}\text { Public Health } \\
\text { Service Drinking } \\
\text { Water Standards } \\
(1962)^{\mathrm{b}}\end{array}$ & $\begin{array}{c}\text { EPA National Interim } \\
\text { Primary Drinking Water } \\
\text { Regulations } \\
(1977)^{\mathrm{c}}\end{array}$ \\
\hline
\end{tabular}

A. INORGANIC CHEMICALS

Arsenic (As)
Barium (Ba)
Cadmium (Cd)
Chloride (Cl)
Chromium ( $\mathrm{Cr}+6$ )
Copper (Cu)
Cyanide (CN)
Fluoride (F)
Iron (Fe)
Lead (Pb)
Manganese (Mn)
Mercury (Hg)
Nitrate (as N)
Selenium (Se)
Silver (Ag)
Sodium (Na)
Sulfate (S0 4 )
Total dissolved solids (TDS)
Zinc (Zn)

Phenols

Vinyl chloride

Benzene

Individual organic

Total organics

Aldrin

Chlordane

DDT

Dieldrin

Endrin

Heptachlor

Heptachlor epoxide

Lindane

Methoxychlor

Toxaphene

2, 4-D

2,4,5-TP (Silvex)

$2,4,5-T$

.05
1.00
.01
250
.05
1.00
.20
1.5
$\mathrm{~h} .30$
.05
$\mathrm{~h} .30$
.002
10.0
.01
.05
$120 ; 270$
250
.-
5.00

.05

1.00

.01

e. 05

--

2.

.05

.002

10.0

.01

.05

$-$

$-$

$-$

B. ORGANIC CHEMICALS

$\begin{array}{ccc}1.0 & 1.0 & - \\ 5.0 & -- & - \\ 5.0 & -- & - \\ 50.0 & - & - \\ 100.00 & - & -\end{array}$

\section{PESTICIDES}

$\begin{array}{rrr}\text { ND } & -- & \mathrm{k}_{1.0} \\ 3.0 & -- & 3.0 \\ \text { ND } & -- & \mathrm{k}_{50} \\ \text { ND } & -- & \mathrm{k}_{1.0} \\ .2 & -- & . .2 \\ .1 & -- & \mathrm{k}_{1} \\ -\overline{4.0} & -- & 4.0 \\ 100.0 & -- & 100.0 \\ 5.0 & -- & 5.0 \\ 100.0 & -- & 100.0 \\ 10.0 & -- & 10.0 \\ -- & -- & \mathrm{k}_{2.0}\end{array}$

a From New York State Department of Environmental Conservation, 1977.

b From U.S. Public Health Service, 1962.

c From U.S. Environmental Protection Agency, 1976.

d This value should not be exceeded if more suitable water supplies are available.

e Total chromium.

f Standard ranges from 0.6 to $1.7 \mathrm{mg} / \mathrm{L}$, depending on annual average of maximum daily air temperature.

g Standard ranges from 1.4 to $2.4 \mathrm{mg} / \mathrm{L}$, depending on annual average of maximum daily a1r temperature.

h Combined concentration of iron and manganese shall not exceed $0.3 \mathrm{mg} / \mathrm{L}$.

1 Applicable to drinking water for those on severely and moderately sodium-restricted diets, respectively.

J Not detectable.

k U.S. Environmental Protection Agency (1973). 